\author{
UNIVERSIDADE DE SÃO PAULO \\ INSTITUTO DE ASTRONOMIA, GEOFÍSICA E CIÊNCIAS \\ ATMOSFÉRICAS \\ DEPARTAMENTO DE GEOFÍSICA
}

Dissertação de Mestrado

Utilização de métodos geoelétricos para auxílio do planejamento de lavra em pedreira de gnaisse

Camila Carroci Martins

São Paulo

2014 
CAMILA CARROCI MARTINS

\section{UTILIZAÇÃO DE MÉTODOS GEOELÉTRICOS PARA AUXÍLIO AO PLANEJAMENTO DE LAVRA EM PEDREIRA DE GNAISSE}

Dissertação apresentada ao Instituto de Astronomia, Geofísica e Ciências Atmosféricas da Universidade de São Paulo para obtenção do Título de Mestre em Geofísica.

Área de concentração: Geoelétrica.

Orientador: Dr. Vagner Roberto Elis

São Paulo

2014 


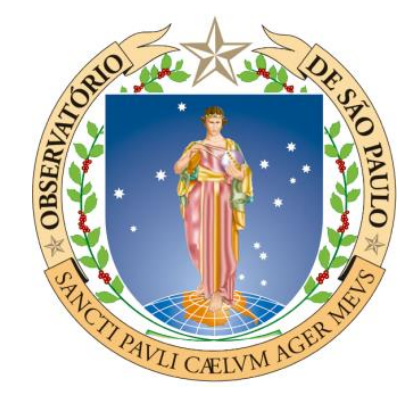

UNIVERSIDADE DE SÃO PAULO

Instituto de Astronomia, Geofísica e Ciências Atmosféricas

\title{
UTILIZAÇÃO DE MÉTODOS GEOELÉTRICOS PARA AUXÍLIO AO PLANEJAMENTO DE LAVRA EM PEDREIRA DE GNAISSE
}

\author{
Camila Carroci Martins
}

\section{DISSERTAÇÃO DE MESTRADO EM GEOFÍSICA}

Prof. Dr. Vagner Roberto Elis - orientador - IAG/USP

Prof. Dr. Giorgio Francesco Cesare de Tomi - Escola Politécnica/USP

Prof. Dr. Cesar Augusto Moreira - IGCE-UNESP/Rio Claro

Versão Corrigida. O original encontra-se disponível na Unidade

São Paulo

2014 
Dedico este trabalho ao meu noivo Caio, a minha família e ao meu orientador o Dr. Vagner Roberto Elis por sempre terem acreditado e confiado em mim. 


\section{Agradecimentos}

Quando eu comecei esta pesquisa, eu era uma pessoa muito diferente da pessoa que o conclui. Logo após minha qualificação eu fui admitida em um processo seletivo e tive que trancar meu mestrado por um ano. Mesmo com esse revés na minha pesquisa, meu orientador nunca deixou de me apoiar e acreditar que eu voltaria para o Brasil para por fim concluir meu mestrado. Agradecer o senhor prof. Vagner R. Elis é muito pouco. Concluir esta pesquisa é o mínimo que eu posso te dar em troca por tudo o que você me ajudou e me ensinou. Obrigada por ter acreditado em mim desde a graduação, sendo meu orientador no Trabalho de Graduação e agora no Mestrado. Além de um ótimo orientador, também ganhei um amigo nesses anos.

Meu noivo foi a primeira pessoa que me incentivou a me inscrever no processo seletivo da Repsol e o primeiro a chorar comigo quando fiquei sabendo que consegui a vaga. Quando voltei ao Brasil e comecei a retrabalhar na minha pesquisa, ele sempre esteve comigo e nunca me deixou acreditar que eu não iria acaba-la. Além disso, sempre leu todos os parágrafos que eu escrevi e sempre foi muito critico quanto a minha escrita e ao conteúdo. Por tudo isso e por muito mais nesses quase oito anos de relacionamento, muito obrigada Caio. Eu te amo.

Para minha família foi muito difícil me ver caminhar pelas minhas próprias pernas. Obrigada por me deixar saber que independente para onde eu vou, eu sempre terei para onde voltar e a quem abraçar. Amo vocês.

Além dessas pessoas tão especiais, não posso deixar de agradecer aos meus amigos de anos, os manolos, que sempre estão comigo e me conhecem tão bem. Também gostaria de agradecer a todos os funcionários do IAG que sempre foram muito solícitos e atenciosos nestes anos.

Por fim, gostaria de agradecer a CNPq pelo financiamento a minha pesquisa. 


\section{Índice}

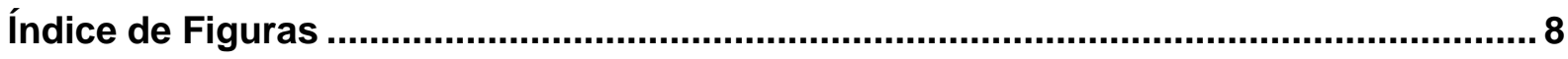

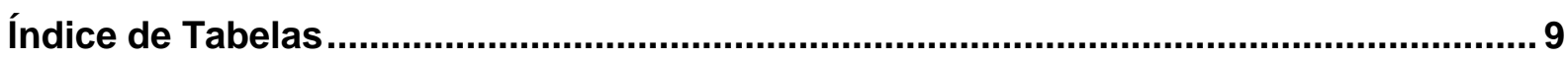

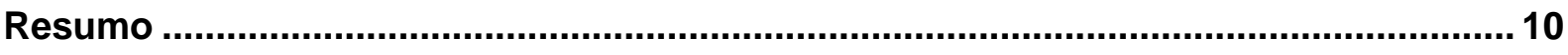

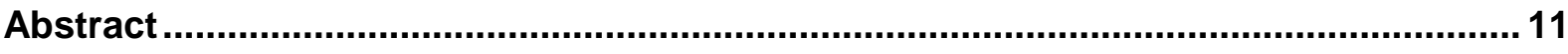

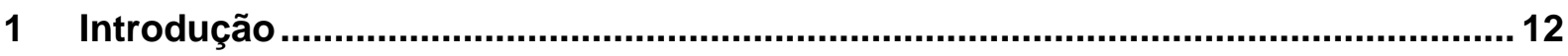

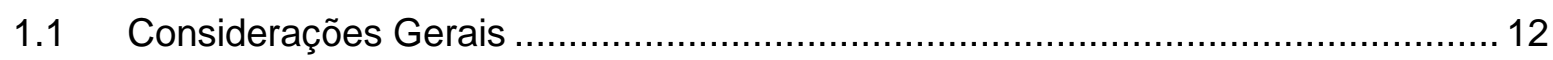

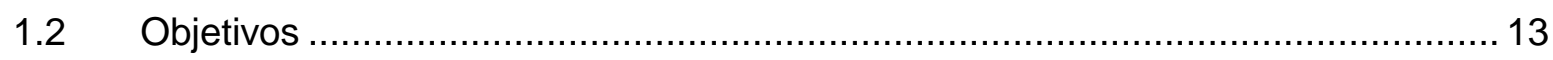

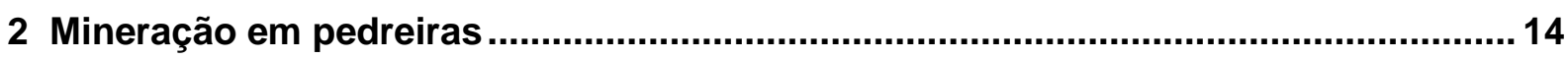

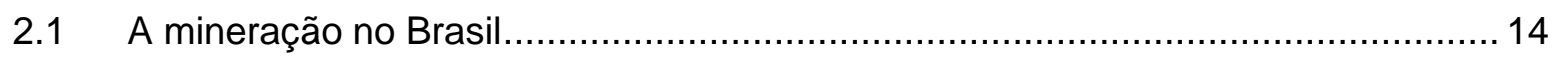

2.1.1 Mineração no Brasil: leis vigentes e órgãos controladores......................................... 15

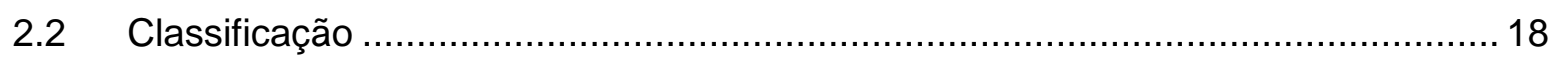

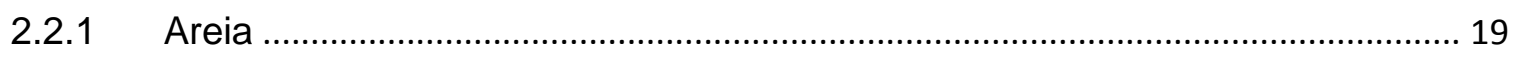

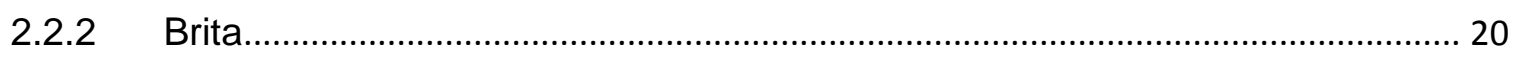

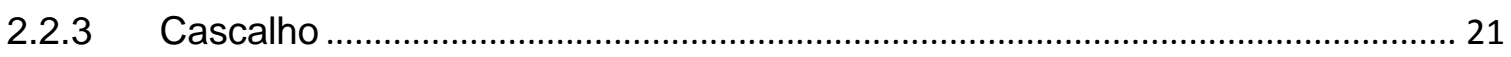

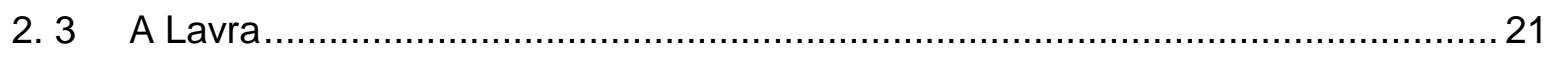

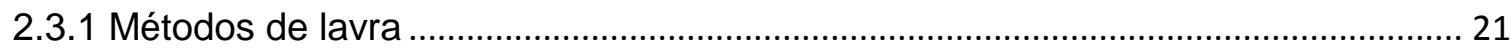

2.3.1.1 Lavra a céu aberto …………………………………………………………... 22

2.3.1.2 Lavra subterrânea .................................................................................................. 22

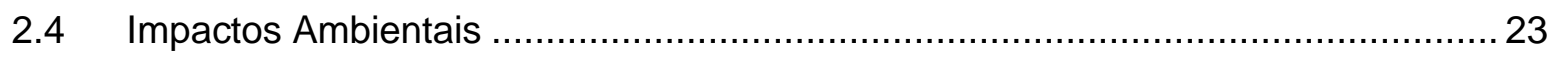

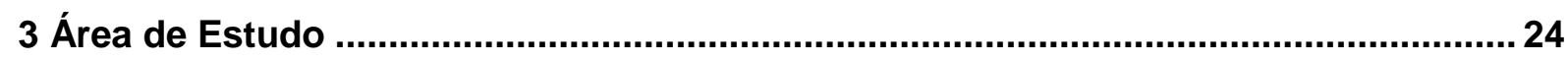

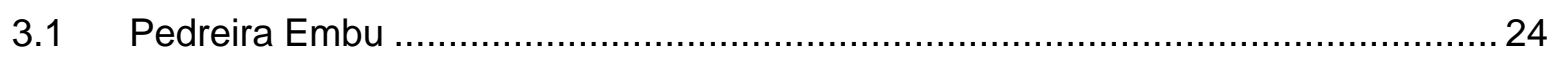

3.1.1 Decapeamento e remoção do material de transição .............................................. 26

3.1.2 Perfuração e desmonte ................................................................................. 27

3.1.3 Carregamento e transporte ................................................................................ 27

3.1.4 Britagem primária ..................................................................................... 27

3.1.5 Rebritagem e Classificação.............................................................................. 27

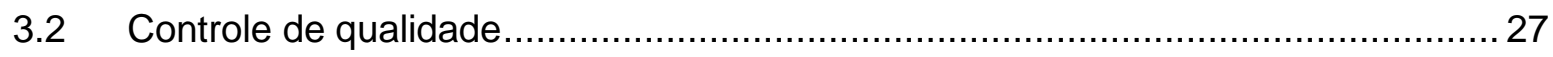

4 Fundamentos Teóricos ................................................................................. 28

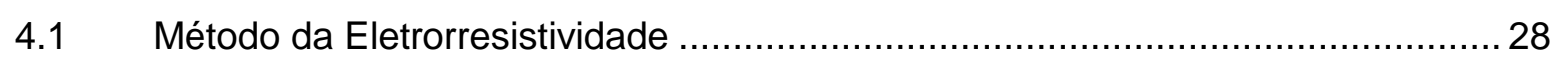

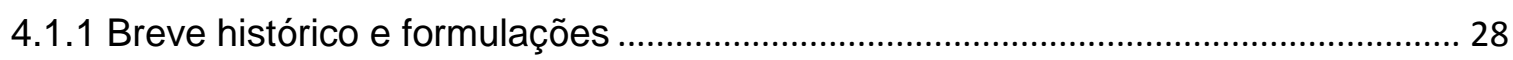

4.1.2 A resistividade aparente ...................................................................................... 34

4.1.3 Técnicas de Investigação......................................................................................... 34

4.1.3.1 Sondagem Elétrica Vertical (SEV) ......................................................................... 35 


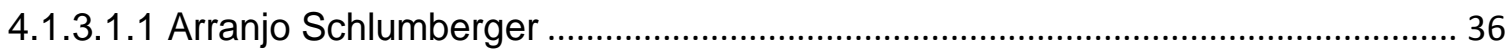

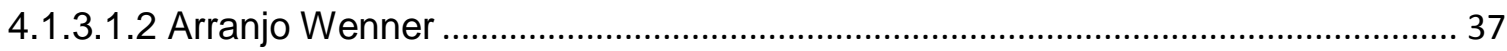

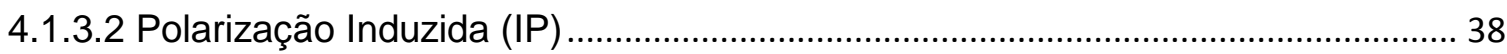

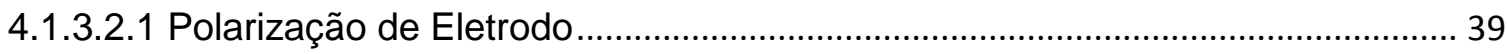

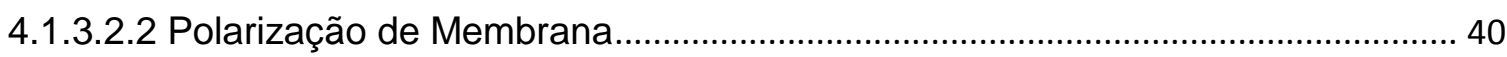

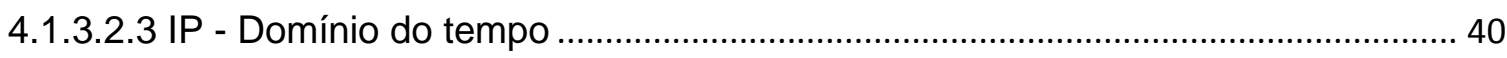

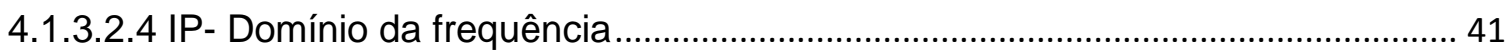

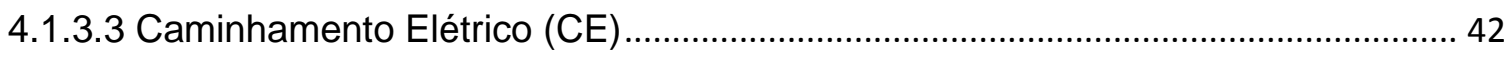

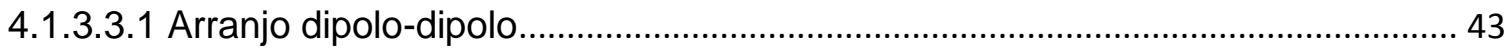

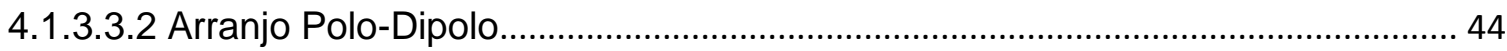

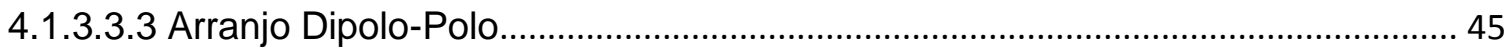

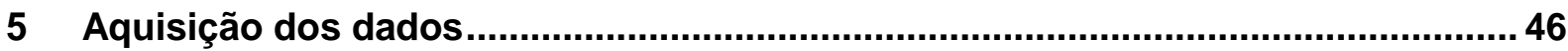

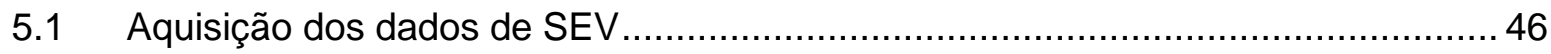

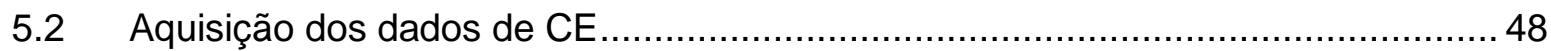

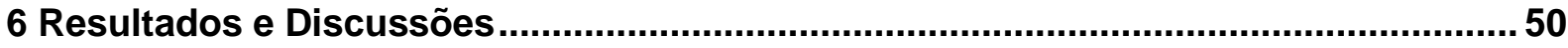

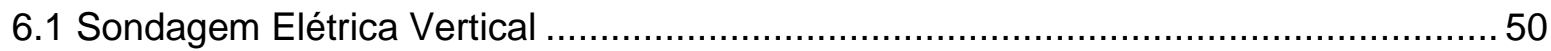

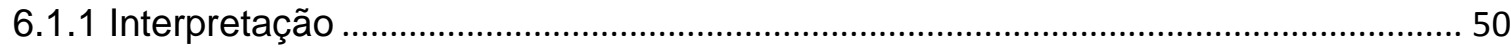

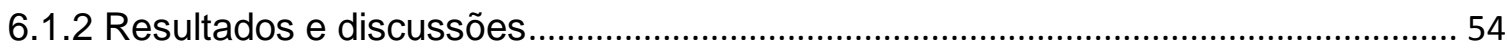

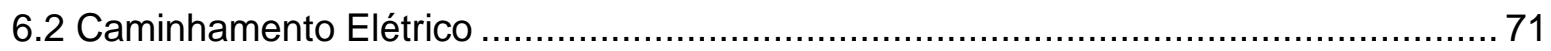

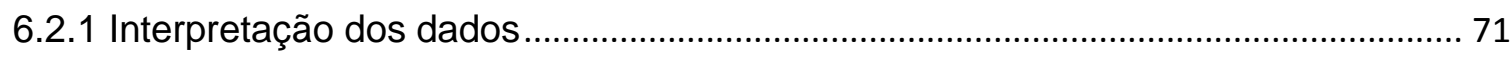

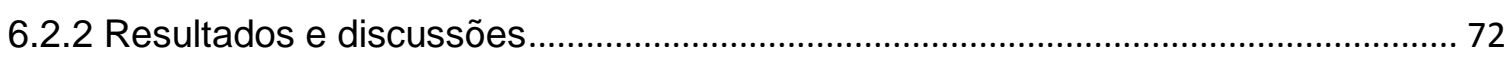

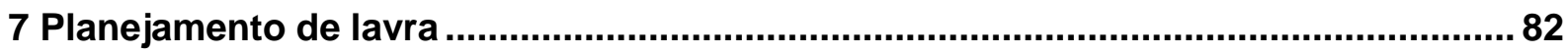

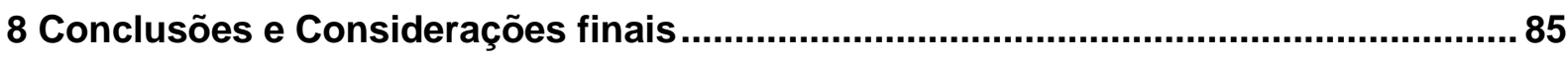

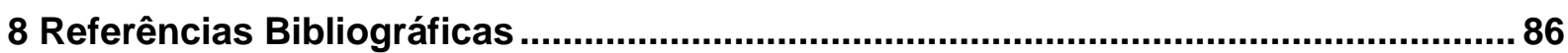




\section{Índice de Figuras}

Figura 2.1: Mercado de brita na Região Metropolitana da grande São Paulo em toneladas, de 2002 a

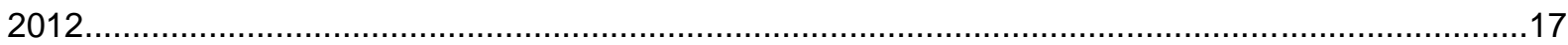

Figura 3.1: Localização de Embu das Artes no Estado de São Paulo...............................................24

Figura 3.2: Imagem da Pedreira Embu.......................................................................................24

Figura 3.3: Visualização esquemática dos processos de produção de uma pedreira...........................25

Figura 4.1: Representação de um cilindro unitário, condutor e homogêneo ......................................27

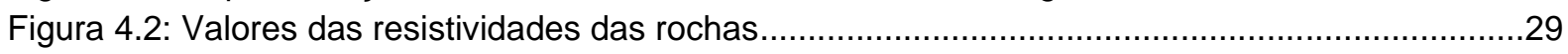

Figura 4.3: Dispersão da corrente elétrica em um meio homogêneo e isotrópico................................31

Figura 4.4: Configuração de ensaios de campo para as técnicas de Sondagem Elétrica Vertical (item

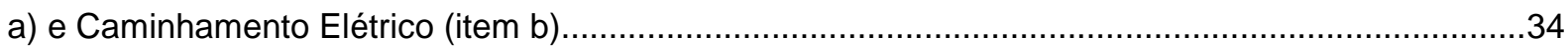

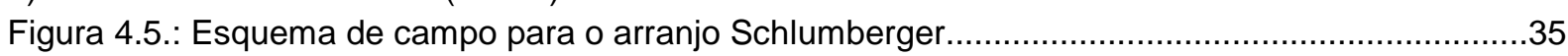

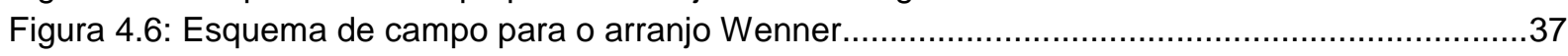

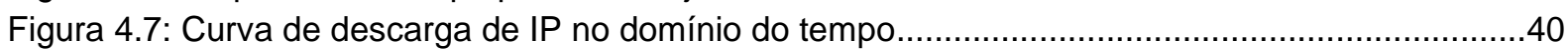

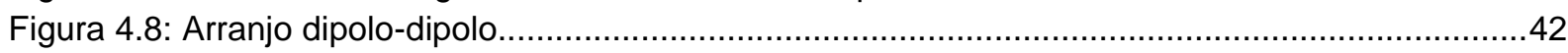

Figura 4.9: Presença da anomalia condutora em um CE com arranjo dipolo-dipolo no software

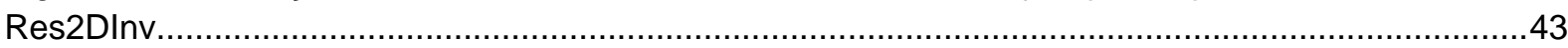

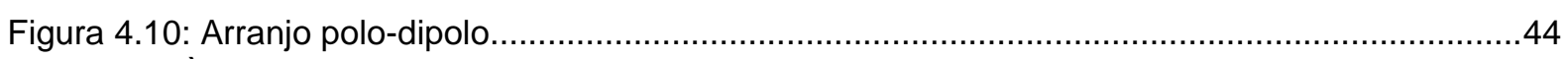

Figura 5.1: À esquerda a unidade do Syscal R2 e a direita a fonte de alimentação do Syscal.............45

Figura 5.2: Esquema de campo levando todos os aparelhos necessários para realizar as medidas de

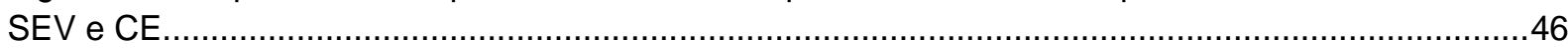

Figura 5.3: Esquema de campo mostrando os dois eletrodos porosos em frente aos equipamentos e

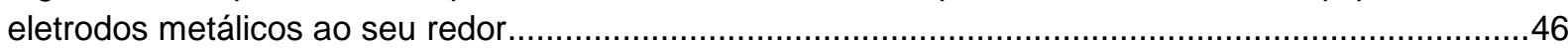

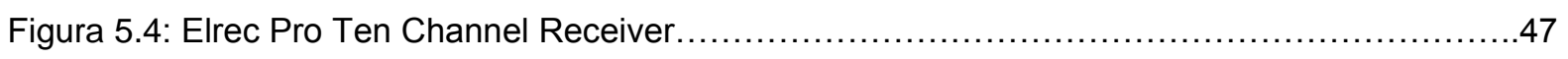

Figura 6.1: Exemplo da criação do modelo inicial para um dado com valores de resistividade e

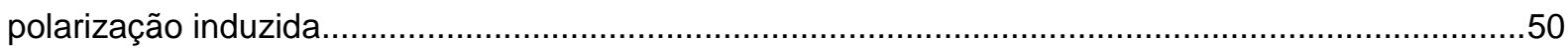

Figura 6.2: Exemplo da saída do programa para um dado com informações de resistividade e

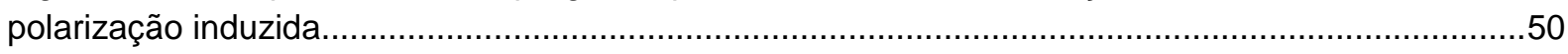

Figura 6.3: Disposição dos dados coletados, onde as setas pretas indicam o sentido dos

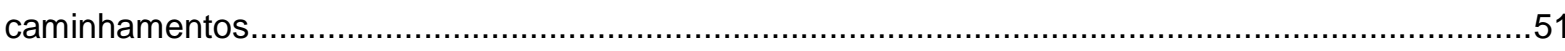

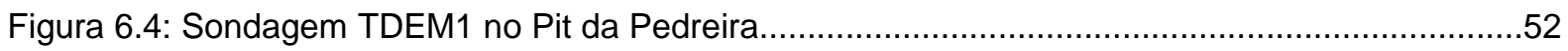

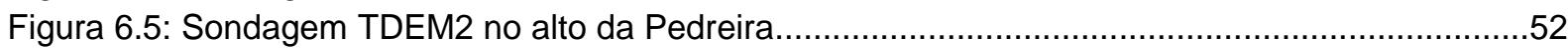

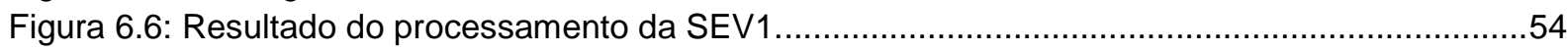

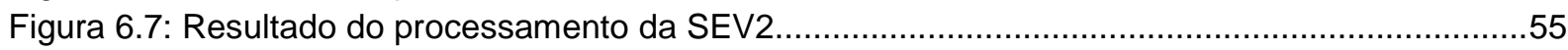

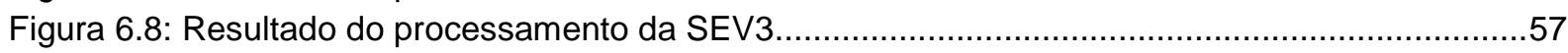

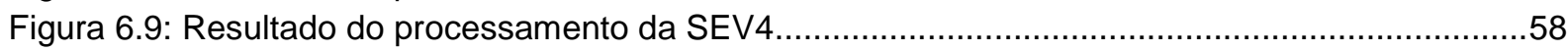

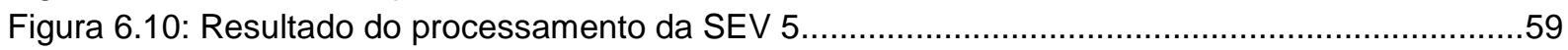

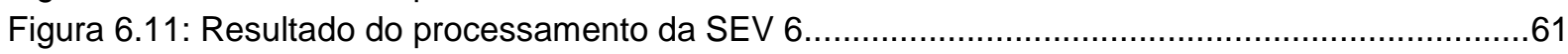

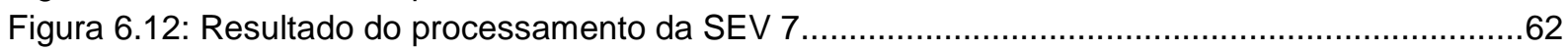

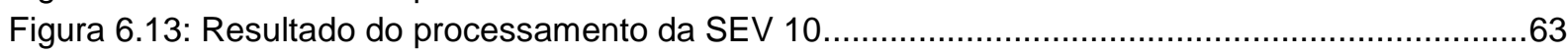

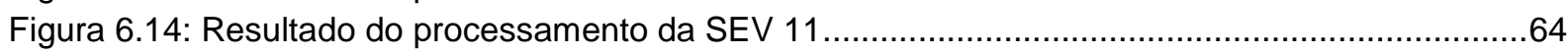

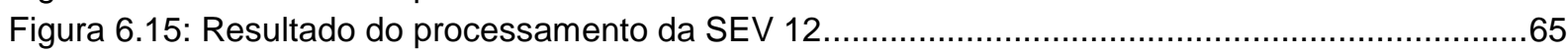

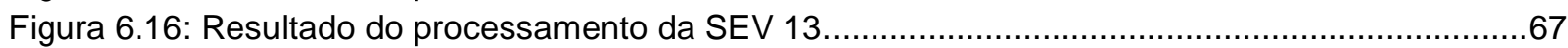

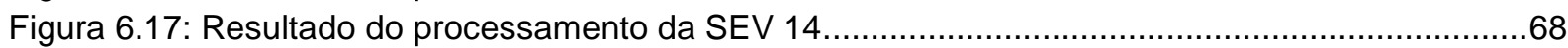

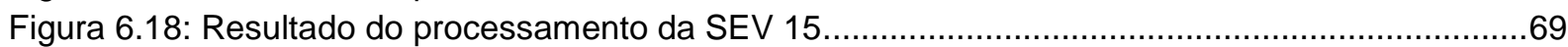

Figura 6.21: Dois possíveis arranjos dos blocos usado para o modelo 2D........................................71

Figura 6.22: Resultado da inversão de resistividade (a) e cargabilidade (b) para o CE01 ...................74

Figura 6.22(c): Resultado da inversão de resistividade (a) para o CE01 com fotos tiradas durante a

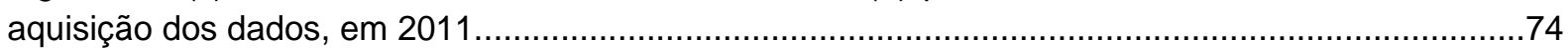

Figura 6.23: Resultado da inversão de resistividade (a) e cargabilidade (b) para o CE03..................75 
Figura 6.23(c): O círculo vermelho na seção de caminhamento representa a área de encontro entre o CE03 e a SEV04 e abaixo, foi reproduzido a SEV04 com a interpretação.

Figura 6.24: Resultado da inversão de resistividade (a) e cargabilidade (b) para o CE04...................78

Figura 6.24 (c): Cópia da seção de resistividade para o CE04, onde o círculo amarelo representa a área de encontro entre o CE04 e SEV07, o círculo vermelho a área entre o CE04 e a SEV06. Já o círculo azul a região de contato entre o CE04 e a SEV05 .78

Figura 6.25: Resultado da inversão de resistividade (a) e cargabilidade (b) para o CE04..................80 Figura 6.25 (c): Cópia da seção de resistividade (a), onde o círculo vermelho representa a área de intersecção entre o CE04 e a SEV10. . .80

Figura 6.26: Mapa geológico com as novas posições dos contatos (traço pontilhado), a partir da interpretação geofísica. As setas vermelhas indicam a direção de aquisição dos caminhamentos.....83

\section{Índice de Tabelas}

Tabela 2.1. Valores quanto ao consumo de agregados para a construção civil nas diferentes regiões brasileiras em 2010

Tabela 2.2. Classificação quanto ao tamanho dos grãos de brita, de acordo com a ABNT NBR 7525 


\section{Resumo}

Este trabalho apresenta e discute resultados de aplicações de métodos geofísicos elétricos como ferramenta de auxílio no planejamento e lavra em pedreira de gnaisse para fabricação de brita. Neste trabalho a espessura do capeamento foi investigada, além de identificar zonas da transição solo-rocha e mapear o contato entre diferentes litologias para avaliar a profundidade do corpo rochoso na base da cava da pedreira. Para isso foram adquiridos treze SEVs e quatro CE em duas frentes de trabalho, a primeira em outubro de 2011 onde foram adquiridos uma parte dos dados de SEVs e todos os caminhamentos elétricos e a segunda frente em fevereiro de 2012 onde foi adquirido o restante dos dados de SEVs. A metodologia utilizada foi a eletrorresistividade e a polarização induzida, diante do histórico de sucesso em aplicações semelhantes. As SEVs possibilitaram delimitar o contato com a rocha sã em subsuperfície, bem como mostrar as relações entre o xisto e o gnaisse, além de identificar uma possível intercalação xisto-gnaisse na porção oeste da pedreira. Ademais as SEVs sugerem que o contato no mapa geológico deve ser reavaliado, especialmente a SEV04, que de acordo com o mapa estaria em área de gnaisse, mas a sondagem apresentou resistividades muito baixas para esse tipo de litologia. Através dos caminhamentos foi possível identificar o contato entre a rocha da jazida, o gnaisse e o xisto em todas as seções. Especificamente as linhas CE02 e CE04 mostraram os contatos entre as litologias um pouco discordantes do esperado pelo mapa geológico da área da pedreira. Dessa forma, foi possível definir melhor os contatos geológicos em algumas áreas e corroborar a interpretação estrutural em outras áreas, de forma a auxiliar o planejamento de futuras frentes de lavra.

Palavras chaves: Eletrorresistividade, Polarização Induzida, Planejamento de lavra, Pedreira para brita, Agregados para a construção civil. 


\section{Abstract}

This work presents end discusses the results of applying electrical geophysical methods as a tool to aid in work front planning in gneiss mine for crushed stones application. This mine produces aggregates for civil construction industry and has a gneiss source rock. In this work the topsoil thickness has been investigated, as well the transitional areas between soil and rock. Moreover the contacts between different lithology have mapped in order to assess the source rock's depth at the mining boundaries. Thereunto thirteen VES and four EP were acquired in two different stages, the first one was performed on October 2011, where a portion of VES and all the EP were acquired. The second stage was on February 2012 to record the rest of VES data. The methodology used was electroresistivity and induced polarization, due the success history of these methodologies in similar applications. VES allowed to define the contact with the bedrock in subsurface and show the relationships between the schist and the gneiss. Moreover those results identified a possible intercalation of schist-gneiss on west portion at the mine. Furthermore the VES suggest a reevaluation in the geological map, mainly where SEV04 took place, because for the map, the contact would be on gneiss environment, but the sounding showed slower resistivity values for this kind of rock. Through the EP was possible to identify the contact between the gneiss and the schist in all the sections. Specifically the lines CE02 and CE04 showed the contact for both lithologies slightly discordant that were expect for the geological map. Thereby was possible to better define the geological contacts in some places and corroborate the interpretation in others, in order to assess the future work front planning for this mine.

Keywords: Eletrorresistivity, Induced Polarization, Work front planning, Mine for crushed stones, Aggregates for the civil construction. 


\section{Introdução}

\subsection{Considerações Gerais}

De acordo com ICMM (2013) o Brasil é hoje amplamente reconhecido como uma economia de mercado emergente e de grande sucesso internacional, integrando junto com Rússia, Índia e China, uma das quatro cadeiras do BRICs (Brasil, Russia, India e China). Este retorno à estabilidade incentivou novos projetos de mineração, sendo a mineração de agregados um agente indispensável no processo de crescimento econômico, como pode ser encontrado dentro dos valores pregados pela ANEPAC (Associação Nacional das Entidades de Produtores de Agregados para Construção Civil). Esta mesma instituição mostra que o setor da mineração apresenta algumas características que torna este setor uma parte única e importante na economia brasileira. Estas características são horizonte de longo prazo, necessidade de mão-de-obra qualificada e não qualificada, vínculos com a infraestrutura regional e a criação de serviços, a importância dos produtos que gera.

O concreto, depois da água, é o segundo material mais consumido em volume pela humanidade e está intimamente ligado ao padrão de vida desfrutado por uma população. A extração de brita sempre teve um papel fundamental na história do Brasil principalmente com a chegada da Corte Portuguesa, pois a demanda pelo desenvolvimento de infraestrutura, construção de novas casas ao recém chegados, aumenta consideravelmente (Silva, M. A. D, 2009). E, nos últimos anos com a facilidade de vendas e financiamento de imóveis que fomenta novas construções, aliados a programas como Programa de Aceleração do Crescimento (PAC), Minha casa minha vida, a Copa do Mundo de Futebol, Olimpíadas Mundiais em 2016, a demanda pela brita vem aumentando num ritmo crescente. Segundo a revista EXAME (2012) a construção no Brasil deve crescer de 3,5 a 4\% em 2013, tornando-se vital o planejamento das pedreiras de extração de brita para estas demandas.

Neste trabalho a Geofísica se insere no ramo da Geologia de Minas, com uma forma de auxiliar o planejamento das atividades futuras em uma pedreira de 
extração de gnaisse. A metodologia utilizada foi a eletrorresistividade que é uma ótima técnica de análise a priori, pois possibilita a obtenção de informações sobre a cobertura inconsolidada e o corpo rochoso de uma forma rápida e pouco danosa ao meio ambiente. Assim é possível planejar mais eficientemente a frente de avanço de lavra do depósito.

\subsection{Objetivos}

O presente trabalho foi realizado em uma pedreira de gnaisse onde os problemas técnicos e ambientais relacionados ao avanço da frente de lavra requeriam formas de análise da área da pedreira que pudessem cobrir de maneira contínua zonas de interesse e com resultados rápidos, o que não pode ser feito de forma economicamente viável com ensaios diretos.

O objetivo desse trabalho foi utilizar ensaios de sondagens elétricas verticais e caminhamentos elétricos para investigar o subsolo na área de pedreira de produção de agregado (brita) visando o mapeamento da espessura do capeamento de solo e identificar zonas da transição solo-rocha, mapeamento de contato entre diferentes litologias e avaliação da profundidade do corpo rochoso na base da cava da pedreira. Essas informações são imprescindíveis ao planejamento do avanço da frente de lavra sob aspectos técnicos e econômicos. 


\section{Mineração em pedreiras}

\subsection{A mineração no Brasil}

No Brasil, rochas para britagem são facilmente encontradas na natureza e são consideradas recursos minerais abundantes, logo viáveis de serem extraídas. O Departamento Nacional de Produção Mineral (DNPM, La Sierna, H. A., 2014) observa que a extração de rocha para brita apresenta as mesmas características da extração de qualquer rocha dura a céu aberto, consistindo em operações unitárias de limpeza e decapeamento, perfuração e desmonte, carregamento e transporte e britagem.

Entretanto deve-se esclarecer que embora em uma pedreira o processo de extração de areia e rocha para britagem seja igual à de uma mineração de recursos metálicos, nem sempre legalmente a mineração em pedreiras é reconhecida como uma mineração típica como a extração de minério de ferro e outros minerais. Com isso frequentemente este setor apresenta problemas jurídicos como a necessidade de licenciamentos mais frequentes, direitos de autoridade não reconhecidos, ações de desapropriação, dificuldade na obtenção de financiamentos, injunções políticas, etc. Logo as exigências e restrições para ambos os setores são os mesmos, mas os impactos ambientais são menores para o caso da mineração em pedreiras. (Valverde, 2001).

As pedreiras são áreas fontes de diversos materiais agregados como a areia, a brita e o cascalho. Estes materiais são usados principalmente na construção civil, sendo o termo "agregados para a construção civil", o que consta na legislação mineral. Este termo é muito empregado no Brasil e, identifica o segmento do setor mineral que produz matéria prima bruta ou beneficiada. Sendo esta matéria prima imediatamente consumida na indústria da construção civil. A viabilidade da exploração depende da qualidade dos materiais, o volume de matéria útil e a localização da jazida.

Os materiais agregados têm como principal uso a confecção de concreto, blocos para revestimento de edifícios, proteção de taludes de barragens, pedra 
britada para os leitos de ferrovias, aeroportos e rodovias, blocos para calçamento de ruas, avenidas, em indústria de cerâmica, de vidro, etc.

Podemos perceber que os materiais agregados são indispensáveis para a expansão urbana. Uma ideia do volume necessário para a construção de algumas obras comuns em um ambiente urbano pode ser encontrado em com Valverde, 2001. Neste trabalho há um levantamento feito pela Fundação Instituto de Pesquisas Econômicas da Universidade de São Paulo (FIPE) para o projeto "Diretrizes para a Mineração de Areia na Região Metropolitana de São Paulo" constatou que:

- em autoconstrução, uma unidade básica de $35 \mathrm{~m}^{2}$ consome 21 toneladas de agregados;

- em habitações populares, uma unidade básica de $50 \mathrm{~m}^{2}$ consome $68 \mathrm{t}$;

- um edifício público de 1.000 m², 1.360 t;

- uma escola padrão de $1.120 \mathrm{~m}^{2}, 1.675 \mathrm{t}$;

- em pavimentação urbana, um quilômetro de via pública de $10 \mathrm{~m}$ de largura consome entre 2.000 t a 3.250 t; um quilômetro de estrada vicinal, 2.800 t e uma estrada pavimentada normal, cerca de 9.500 t por quilômetro.

Os números acima podem parecer elevados, o que acarretaria em um alto custo para a construção civil. Mas na pratica isso não acontece, pois os insumos minerais para a construção civil são amplamente utilizados por serem produtos de baixo custo e consequentemente acessíveis à população. Sendo assim a probabilidade da substituição em massa da areia e da brita por outros recursos minerais é quase nula.

\subsubsection{Mineração no Brasil: leis vigentes e órgãos controladores}

No Brasil há vários órgãos e entidades que controlam a extração mineral e a mineração dos agregados para a construção civil. A grande entidade regularizadora é o Ministério do Meio Ambiente que cria leis visando preservar o meio ambiente como um todo. Sendo o DNPM (Departamento Nacional de Produção Mineral) o grande centralizador das informações sobre a produção mineral brasileira. Em 29 de março de 2006, foi publicada no DOU número 61, seção 1, páginas 150 e 151; a 
Resolução CONAMA n 369 , relativa a áreas protegidas quanto à preservação permanente. Esta é uma resolução importante para a mineração de agregados.

De acordo com a Sindipedras em 2013 São Paulo era o maior produtor de pedra britada do Brasil tendo mais de 160 unidades produtivas, onde somente na região metropolitana de São Paulo existem 34 pedreiras em 12 diferentes municípios, há de se esperar que além do Ministério do Meio Ambiente exista no estado outros órgãos relacionados à indústria de mineração. Duas grandes entidades que podem ser citadas é o Sindipedras e a ANEPAC. O Sindipedras é o sindicato das indústrias de mineração e pedra britada do estado de São Paulo reconhecido em 2 de dezembro de 1974 como sindicato pelo Ministério do Trabalho, e, filiado ao FIESP (Federação das Industrias do Estado de São Paulo) luta principalmente por congregar e representar as indústrias de mineração de pedra britada, defendendo seus direitos e legítimos interesses. Outra associação que pode ser citada é a ANEPAC (Associação Nacional das Entidades de Produtores de Agregados para Construção Civil) que é uma associação sem fins lucrativos fundada em 10 de maio de 1995. Dentre seus objetivos principais, pode-se destacar a contribuição para o pleno desenvolvimento de todas as entidades representativas dos produtores de areia e brita em funcionamento no país; a execução de ações esclarecedoras que permitam a compreensão adequada da contribuição do segmento de areia e brita a sociedade.

No website desta associação (www.anepac.org.br) é possível encontrar diversas informações quanto à produção e demanda do mercado brasileiro. Muitas dessas informações estão sintetizadas abaixo.

- "A partir dos números de brita e areia por estado e considerando os preços do IBGE convertidos para tonelada e eliminado o frete, pode-se considerar o faturamento de agregados no Brasil como sendo de $R \$ 22.590 .071 .817,00$ correspondente a $0,615 \%$ do PIB brasileiro, no ano de 2010."

- Quanto ao transporte de agregados, a utilização de caminhões é total. Para uma média anual de 275 dias úteis, o transporte de agregados esta na casa de 2.300.000t. Resumindo, pode-se dizer que em 2010, o Brasil tinha diariamente cerca de 22.000 caminhões envolvidos no transporte dos agregados. 
Esses números mostram o quanto à produção de agregados move a economia brasileira.

Os insumos para a construção civil são consumidos em sua grande maioria na forma de cimento (normalmente para a preparação do concreto é necessário uma mistura de $10 \%$ de cimento, $7 \%$ de água, $42 \%$ de brita, $40 \%$ de areia e $1 \%$ de aditivos químicos) Quanto ao consumo por regiões os dados de 2010 podem ser sumarizados na tabela 2.1, também disponibilizada pela ANEPAC. Sendo que neste ano o Brasil contabilizou 3,31t/habitante. A projeção é que esse número cresça ainda mais devido a construção dos estádios da Copa do Mundo de futebol neste ano e as arenas olímpicas em 2016.

Tabela 2.1. Valores quanto ao consumo de agregados para a construção civil nas diferentes regiões brasileiras em 2010.

\begin{tabular}{lc}
\hline \multicolumn{1}{c}{ Regiões } & $\begin{array}{c}\text { Consumo de Agregados } \\
(\mathrm{t})\end{array}$ \\
\hline Região Norte & 43.175 .411 \\
Região Nordeste & 128.122 .364 \\
Região Centro Oeste & 55.832 .105 \\
Região Sudeste & 303.345 .237 \\
Região Sul & 101.265 .270 \\
BRASIL & $\mathbf{6 3 1 . 7 4 0 . 3 8 7}$ \\
\hline
\end{tabular}

Somente no estado de São Paulo que é onde esta localizada a pedreira Embu, foco de estudo deste trabalho; o sindicato da Sindipedras disponibiliza no seu website a estatística sobre o mercado de brita na região metropolitana de SP para os anos de 2002 a 2012 em toneladas, Figura 2.1. 


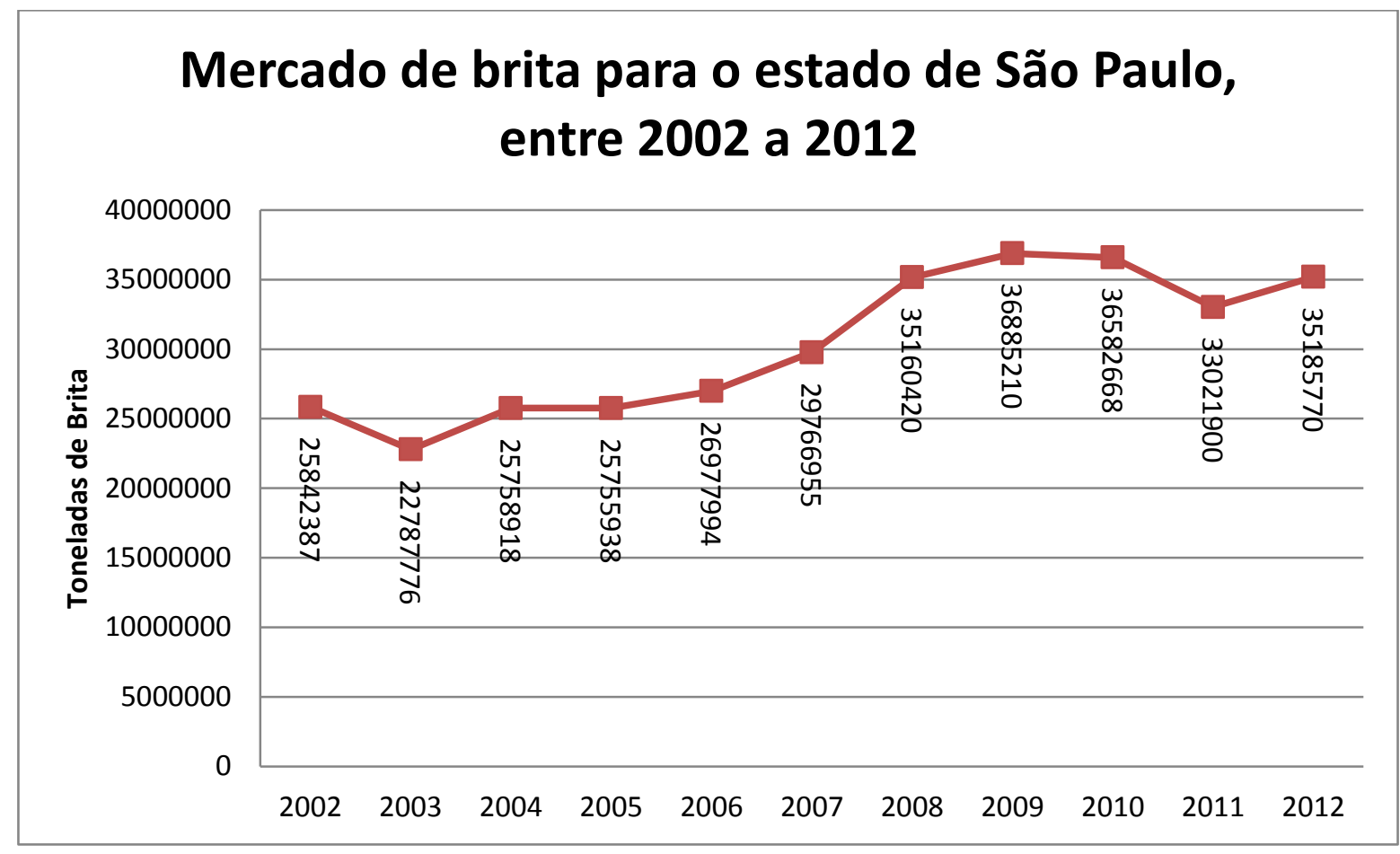

Figura 2.1. Mercado de brita na Região Metropolitana da grande São Paulo em toneladas de 2002 a 2012

Sendo que essa cadeia de consumo que tem por base o concreto inicia-se com as atividades de localização e avaliação da quantidade e qualidade da rocha bruta.

\subsection{Classificação}

De acordo com o Sumário Mineral Brasileiro 2010 disponibilizado pela DNPN, os agregados para a Construção Civil são materiais granulares, sem forma e volume definidos tem propriedades estabelecidas para uso em obras de engenharia civil (pedra britada, cascalho e areias naturais), ou são obtidas entre outras coisas, através da cominuição de rochas. Estabelecer com precisão as propriedades físicas e químicas dos agregados e das misturas ligantes é extremamente importante para o cálculo da vida útil das obras que serão construídas com esses materiais. Para evitar assim, a falência de estruturas devido à má seleção ou o uso inadequado dos insumos.

Os materiais agregados da construção civil apresentam características químicas muito peculiares entre si e são classificados quanto à origem, densidade e tamanho dos fragmentos. 
Quanto à origem, os insumos podem ser classificados como naturais ou artificiais. Os materiais naturais são aqueles materiais que foram extraídos da área fonte na sua forma fragmentada, como a areia e o cascalho. Já os materiais artificiais são aqueles que foram extraídos em blocos e, portanto precisam passar por processos industriais como a fragmentação, por exemplo a brita e a areia britada.

Quanto a densidade, existem matérias de densidade leve (agregados leves) como a pedra pomes e a vermiculita, agregados normais como brita, areia e cascalho e agregados pesados como a barita (mineral de sulfato de Bário) e a magnesita.

Considerando o tamanho, a norma ABNT NBR especifica duas faixas relacionadas ao diâmetro. Agregados miúdos, diâmetro entre 0,075mm até 4,8mm, como as areias de origem natural e agregados graúdo ou pedregulhos, diâmetros entre 4,8mm até 152mm, como o cascalho e a brita (Pormin1, 2012).

Quanto às diferenças químicas, tem-se a classificação encontrada em Pormin1 (2012) e em Quaresma (2009).

\subsubsection{Areia}

As areias provem da desagregação de rochas, principalmente aquelas com altos teores de quartzo. Consequentemente este é o seu maior constituinte. Possui fórmula geral $\mathrm{SiO}_{2}$ e de acordo com a ABNT possui granulometria variando entre 0,05 e $5 \mathrm{~mm}$. A granulometria e o grau de pureza da areia define o emprego da mesma. Areias grosseiras e impuras são utilizadas na construção civil, enquanto as areias com baixo teor de ferro são utilizadas na fabricação de vidros e na indústria cerâmica refratária. E, areias com alta concentração de sílica são usadas na siderurgia para confecção de ligas ferro-silício.

A areia pode ser usada em concreto, argamassa de assentamento e revestimento, pavimentação asfáltica, em filtros de água, lastro e em permeabilização de vias e pátios. 


\subsubsection{Brita}

A brita é o produto do processo da cominuição de vários tipos de rocha. Este nome é um termo utilizado para se referir a fragmentos de rochas duras originados de blocos maiores como granito, gnaisse, basalto e calcário, através da explosão desses blocos maiores com explosivos. Com isso, a brita tem como principal área fonte pedreiras de rochas cristalinas de preferência com rochas contendo quartzo como granito e gnaisse, com solos pouco espessos sem muita alteração. Mas pedreiras com rochas basálticas e de calcário microcristalinos também são exploradas. Segundo Quaresma (2009) no Brasil cerca de $85 \%$ da brita produzida vem de granito/gnaisse, $10 \%$ de calcário/dolomito e 5\% de basalto/diabásio.

A textura da rocha fonte deve ser coesa e não muito grossa, com baixa porosidade, ausência de plano de fraqueza ou estrutura isotrópica. As principais rochas que produzem a brita são em sua maioria granitos e gnaisses e, em menor parcela, calcário e dolomito, seguido por basalto e diabásio. Os minerais dielétricos devem ser evitados na exploração e são preferíveis rochas com minerais desagregados como micas e feldspatos. A forma também é muito importante, pois grãos angulosos e rugosos aderem-se mais facilmente ao cimento que grãos arredondados e lisos. De acordo com ABNT NBR 7525 os tamanhos dos grãos são classificados como na tabela 2.2 .

Tabela 2.2. Classificação quanto ao tamanho dos grãos de brita, de acordo com a ABNT NBR 7525 .

\begin{tabular}{cc}
\hline Numeração & Tamanho $(\mathrm{mm})$ \\
\hline № 1 & 4,8 a 12,5 \\
№ 2 & 12,5 a 25 \\
№ 3 & 25 a 50 \\
№ 4 & 50 a 76 \\
№ 5 & 76 a 100 \\
\hline
\end{tabular}

A brita é destinada em menor escala para revestimento de leito de estradas de terra, ferrovias, barramentos, em lastros de vias aéreas e em filtros de água. Mas sua maior utilização é na fabricação de concreto, onde suas principais funções são contribuir com grãos capazes de resistir aos esforços; resistir ao desgaste à ação de intempéries; reduzir as variações de volume de qualquer natureza e contribuir para a redução do custo do concreto. 


\subsubsection{Cascalho}

O cascalho é a denominação genética de seixos que provem da fragmentação natural da rocha fonte. Pertence a uma faixa granulométrica entre $2 \mathrm{e}$ $256 \mathrm{~mm}$ de diâmetro.

O cascalho é destinado para setores da construção civil com aplicações na fabricação de concreto, revestimento de leito de estradas de terra, concreto ciclópico, ornamentação de jardins, etc.

Como os outros insumos da construção civil, o cascalho ocorre em toda a crosta terrestre, sendo encontrados principalmente em barras de rios oriundo do intemperismo e transporte de sedimentos.

\section{3 A Lavra}

A lavra é uma atividade de extração que transforma a matéria bruta em matéria prima para suprir uma enorme gama de ramos industriais.

\subsubsection{Métodos de lavra}

Visando à viabilidade econômica intrínseca neste tipo de atividade, deve-se escolher um método de lavra adequado dependendo do tipo de rocha a ser explorada. Uma vez que uma escolha equivocada pode inviabilizar o projeto. Uma vez que o método é elaborado em torno da técnica utilizada para lavrar a matéria bruta. Segundo Pormin2 (2012) esta escolha se baseia em critérios geológicos, sociais, geográficos e ambientais. Além de levar em conta aspectos tecnológicos, políticos, sociais e econômicos.

Um primeiro aspecto a ser estudado é a profundidade e a extensão do capeamento, pois estes fatores dão uma indicação preliminar quanto à técnica a ser utilizada. Outros fatores são o mergulho do corpo: suave (horizontal a $20^{\circ}$ ), médio $\left(20^{\circ}\right.$ a $\left.50^{\circ}\right)$ ou íngreme $\left(50^{\circ}\right.$ a vertical). A espessura: estreito $(<10 \mathrm{~m})$, intermediário (10 m a $30 \mathrm{~m}$ ), espesso $(30 \mathrm{~m}$ a $100 \mathrm{~m}$ ) ou muito espesso (superior a $100 \mathrm{~m}$ ) (Nicholas, 1968 apud Pormin2, 2012), e a forma do depósito. Além de tudo isso, deve-se levar em conta o teor de minério e sua distribuição espacial, analisar as 
águas subterrâneas e superficiais quanto à forma de drenagem e bombeamento; considerações geotécnicas sobre o maciço rochoso e a geologia no geral.

Após estas primeiras análises, escolhe-se um tipo de método de lavra. De acordo com Pormin1 (2012) e os principais tipos aplicados no Brasil são:

\subsubsection{Lavra a céu aberto}

Este método é o mais tradicional e consiste em bancadas ou encostas dependendo das condições topográficas do terreno. A profundidade máxima da cava depende diretamente do teor e da relação estéril/minério, no caso de uma mina, como as dimensões das plataformas de trabalho dependerão da produção e da conveniência dos equipamentos;

\subsubsection{Lavra subterrânea}

O segundo método mais comum no Brasil, consiste no desenvolvimento da lavra no subsolo devido a geometria do corpo (inclinação e espessura) e resistência e estabilidade do maciço. Este método pode variar quanto à abertura de poços, túneis e galerias; ou quanto à aplicação de métodos e técnicas mais sofisticadas como, realce auto-portantes (câmeras e pilares, subníveis e VCR - Vertical Crater Retreat), suporte de encaixes e abatimento em minas. 


\section{$2.4 \quad$ Impactos Ambientais}

Segundo Quaresma (2009) a mineração de rochas para insumos da construção civil apresenta as seguintes características:

- Uso e ocupação do solo temporariamente, logo é possível a recuperação do solo no futuro. Além da remoção de vegetação e alteração temporária de ecossistemas locais.

- Não apresenta o uso de substâncias químicas poluentes no processo produtivo, com exceção dos combustíveis e lubrificantes, usados em pequena escala em comparação com outras indústrias;

- O uso de explosivos para a lavra da rocha bruta, culminando com o risco de lançamento de fragmentos de rocha a longa distância (fora do perímetro da área da propriedade).

- Alteração da paisagem;

- Impactos ambientais como ruído de máquinas e equipamentos e da quebra ou perfuração de rocha; emissão de poeira na atmosfera no processo de beneficiamento e no tráfego de caminhões dentro da área de operação ou em estradas de acesso à mina;

- Interferência com as "Áreas de Proteção Permanente" como topos de morros, encostas com declividade superior a 45ํㅡㄴ, nascentes e drenagens.

Com essas características, nota-se que a mineração de rocha para brita não traz danos ambientais tão graves se comparada com a extração de minerais metálicos. O rejeito do processamento é constituído de material inerte, lama do processo de lavagem e classificação da brita contendo material argiloso. $\mathrm{O}$ grande problema desse tipo de atividade é a mudança na paisagem típica da área que esta sendo explorada. 


\section{3 Área de Estudo}

\subsection{Pedreira Embu}

A empresa Embu S/A Engenharia e Comércio é responsável pela mineração da Pedreira Embu e atua no mercado há 50 anos, recebendo em 2013 o prêmio de melhor empresa do Brasil. A empresa tem três jazidas em São Paulo, Pedreira Embu, Pedreira Itapeti e Pedreira Juruaçu; e uma em Vila Velha no Espírito Santo, Pedreira Rydien Mineração. (Embusa, 2012). Esta empresa aparecia em 2009 em terceiro lugar entre os principais produtores de brita no Brasil, somente ficando atrás dos grupos Votorantim e Estrutural (Quaresma, 2009).

A pedreira Embu esta localizada na Estrada Maria José Ferraz Prado, 3100. Bairro Itatuba, Município Embu das Artes, distante $30 \mathrm{~km}$ de São Paulo. Esta pedreira produz agregados para a construção civil tendo como rocha fonte o gnaisse. A região de Embu está inserida dentro do embasamento cristalino do Estado de São Paulo (Figura 3.1). A Figura 3.2 apresenta uma imagem aérea da pedreira.

De acordo com Alves (2012) na área da pedreira afloram três unidades litológicas: o gnaisse migmatítico, que ocorre na maior parte da área e é a rocha lavrada; o sillimanita biotita xisto, que ocorre em contato com o gnaisse com mergulho para SE; e ainda há pontos coletados em campo indicando a presença de outro tipo de rocha aqui denominado sillimanita xisto milonítico. Neste trabalho, para simplificar os tipos litógicos serão tratados como gnaisse, xisto e xisto milonítico. 


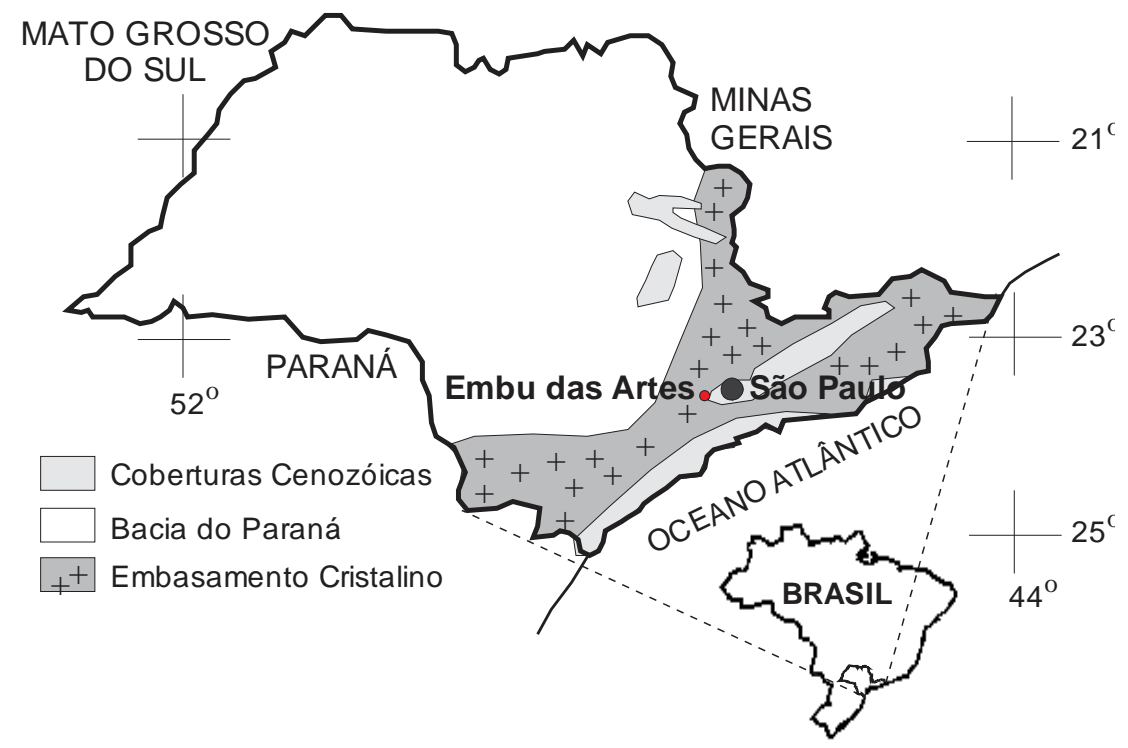

Figura 3.1 - Localização de Embu das Artes no Estado de São Paulo.

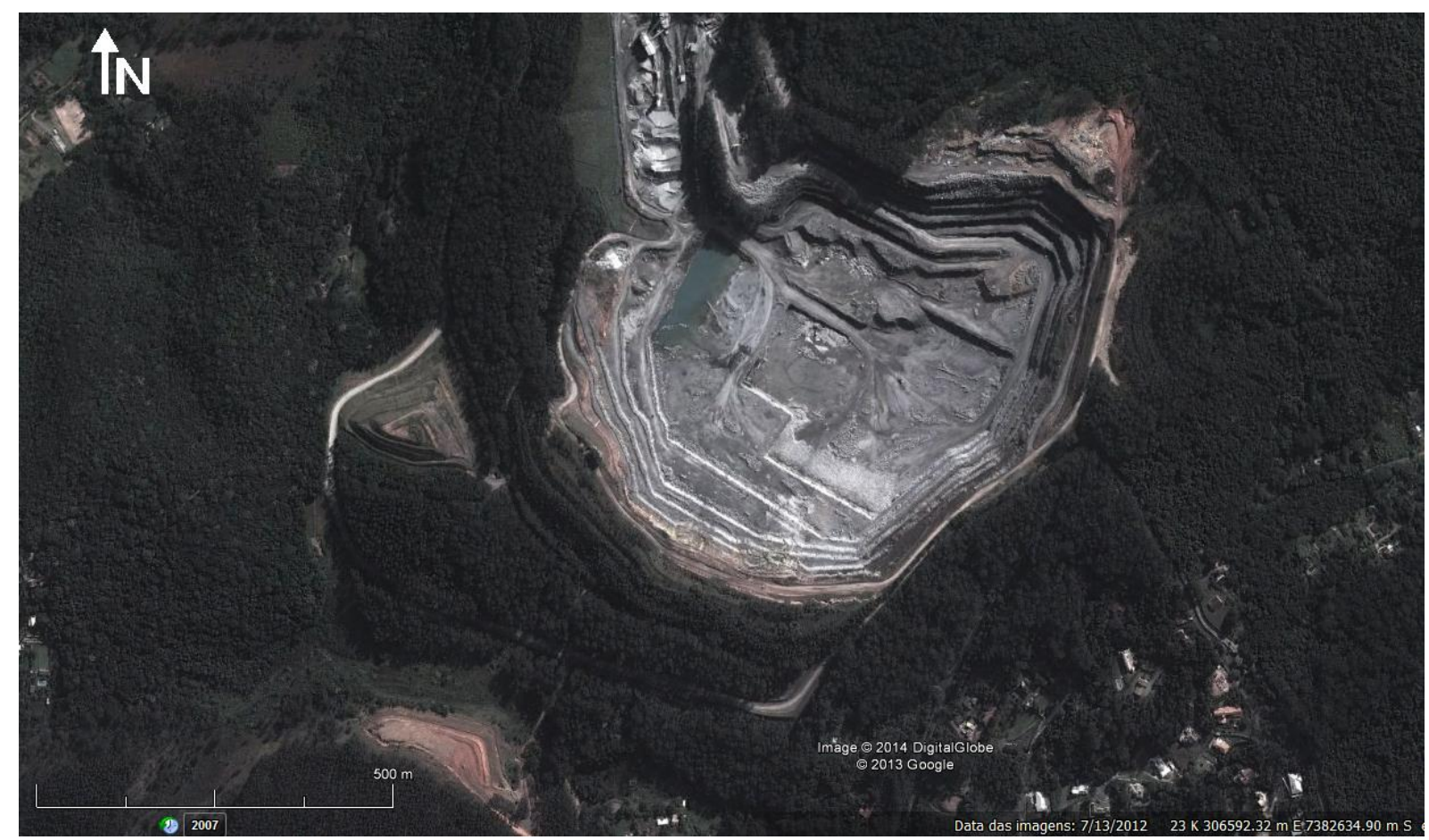

Figura 3.2 - Imagem da Pedreira Embu retirado do Google Earth.

O processo de produção aplicado na pedreira Embu pode ser dividido nos seguintes estágios:

1.Decapeamento e remoção de material de transição;

2.Perfuração e desmonte;

3.Carregamento e transporte;

4.Britagem primária; 
5.Rebritagem e classificação;

6.Controle de qualidade;

Os processos podem ser visualizados na Figura 3.3. E uma explicação detalhada encontra-se abaixo.

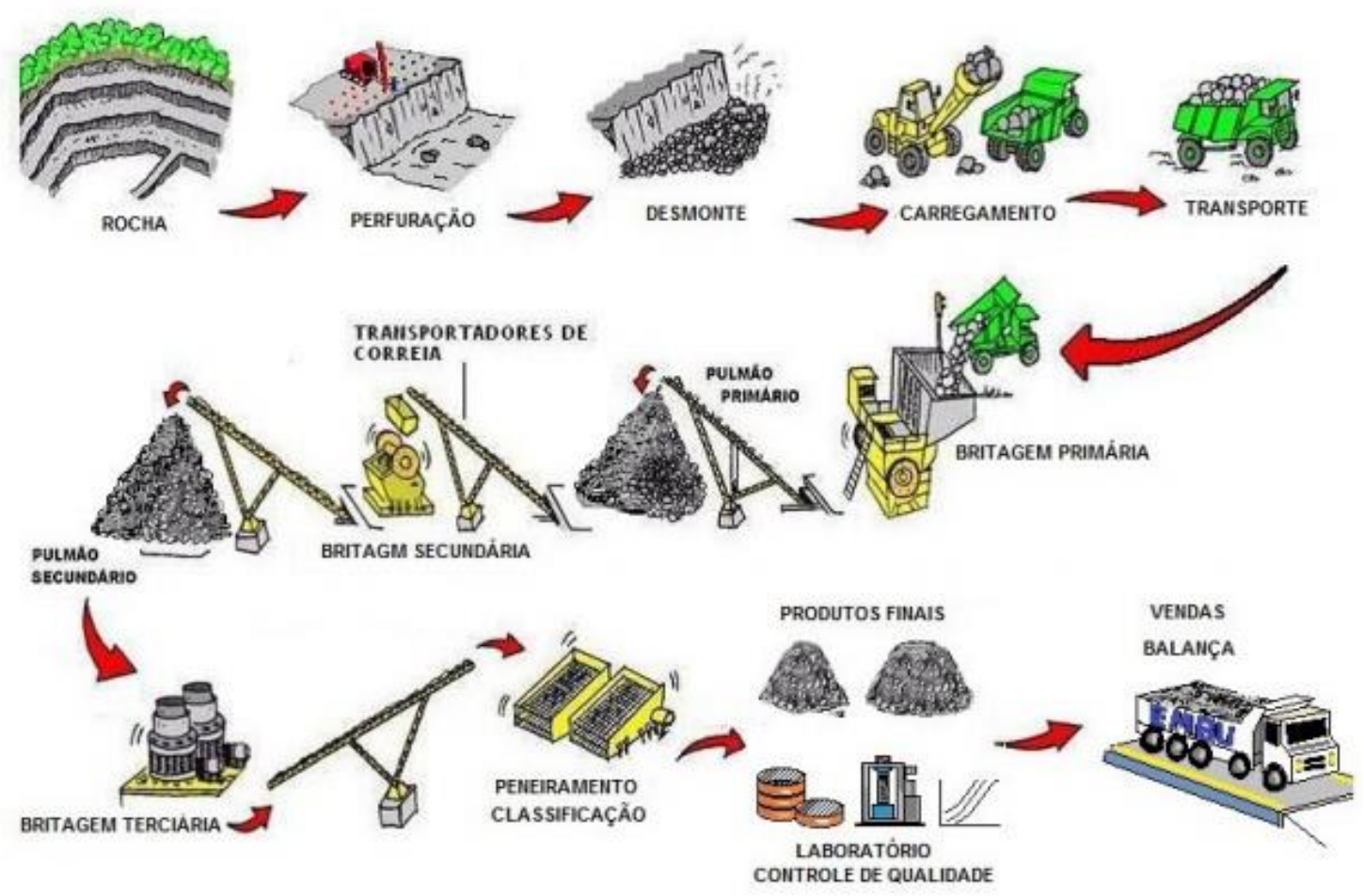

Figura 3.3: Visualização esquemática dos processos de produção de uma pedreira, Embusa (2012).

\subsubsection{Decapeamento e remoção do material de transição}

A primeira etapa é a remoção do material de capeamento, isto é, solo vegetal e solo residual, que recobre o maciço rochoso. Esta remoção normalmente se da por processos mecânicos, onde uma ferramenta abrasiva passa pela superfície, garantindo a integridade estrutural do embasamento (IME, 2012).

Com a remoção do material de capeamento, tem-se acesso a rocha de interesse. Entretanto, devido ao intemperismo inerente com o passar dos anos, a rocha apresenta alterações. O material entre a rocha e a superfície capeadora deve ser retirada. 


\subsubsection{Perfuração e desmonte}

Normalmente utilizam-se explosivos para perfurar a rocha, onde a determinação da quantidade de explosivos, o arranjo geométrico e outras variáveis, são calculados empiricamente.

\subsubsection{Carregamento e transporte}

Após o material ser desmontado, ele é transportado para a britagem primária, iniciando o beneficiamento.

\subsubsection{Britagem primária}

A britagem consiste em fragmentar e quebrar os blocos oriundos da lavra. Após a britagem o material vai para pilhas.

\subsubsection{Rebritagem e Classificação}

A rebritagem ou britagem secundária acontece imediatamente após a britagem primária, através do processo de cominuição. Pode acontecer a britagem terciária ou quartenária, ambas visando diminuir a granulometria do material.

Durante os processos de britagem, há continuas etapas de peneiramento e classificação quanto ao tamanho dos grãos. Resultando basicamente em quatro produtos comerciais (Sampaio e Salvador, 2002):

- Brita 3 (diâmetro entre 70 e 50mm);

- Brita 1 (diâmetro entre 25 e 12,5mm);

- Brita 0 (diâmetro entre 12,5 e 4,8mm);

- Pó de pedra (diâmetro inferior a 4,8mm);

\subsection{Controle de qualidade}

Etapa onde o material é devidamente averiguado quanto a tamanho e qualidade. Depois dessa etapa o produto está pronto para a venda. 


\section{Fundamentos Teóricos}

\subsection{Método da Eletrorresistividade}

\subsubsection{Breve histórico e formulações}

O método da eletrorresistividade busca determinar a resistividade elétrica do substrato da Terra. Para isso emprega uma corrente artificial injetada no terreno a partir de dois eletrodos denominados eletrodos de corrente A e B. Então, são medidas na superfície as diferenças de potencial, através de dois eletrodos denominados eletrodos de potencial $\mathrm{M}$ e $\mathrm{N}$. Com isso é possível criar um modelo para o comportamento das propriedades elétricas do meio na subsuperfície da Terra, através da resistividade elétrica. Embasado em propriedades elétrica, é possível associar os valores da resistividade a diferentes materiais geológicos.

A resistividade é uma propriedade física intrínseca aos materiais geológicos. Ela é o inverso da condutividade elétrica e pode ser definida como a resistência em Ohm em conduzir corrente elétrica entre as faces de um cilindro unitário, condutor e homogêneo de material, cuja resistência é dada por $d R$, comprimento $d L$, e área de seção transversal $d A$ (Figura 4.1).

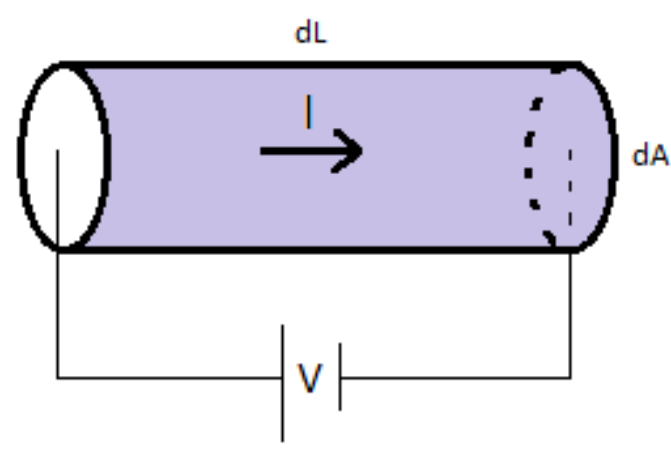

Figura 4.1: Representação de um cilindro unitário, condutor e homogêneo.

A resistividade depende da natureza e do estado físico dos materiais e relacionam-se aos mecanismos de propagação de corrente elétrica nos materiais. Assim a resistividade elétrica é dada por:

$$
\rho=\frac{d R d A}{d L}
$$


No sistema internacional de unidades ( $\mathrm{SI}$ ) a unidade da resistividade é o Ohm.metro (Ohm.m). Para um valor de resistividade mais confiável é importante que a medida seja feita perto do fluxo de corrente em subsuperfície (Bhattacharya, P.K e Patra, H. P., 1968).

A resistividade é muito variável e depende do tipo de material geológico. A corrente elétrica pode ser propagada nas rochas de três maneiras distintas: via condutividade eletrônica, eletrolítica ou condução dielétrica (Telford, 1990). A condutividade eletrônica acontece em materiais com elétrons livres como os metais. Porém a maior parte dos minerais nas rochas é isolante e a corrente elétrica é conduzida devido ao deslocamento de íons dissolvidos nas águas intersticiais ou nas fissuras de solos e rochas, chamado de condutividade eletrolítica. Na prática a condutividade é eletrolítica, pois apenas em alguns casos os minerais condutores ocorrem em número suficiente nas rochas para aumentar a condutividade eletrônica.

A condutividade eletrolítica é afetada principalmente pela composição mineralógica, porosidade, teor de água e quantidade e natureza dos sais dissolvidos. Desses fatores a quantidade e a salinidade das águas intersticiais são os fatores mais importantes, pois, o aumento desses fatores leva a diminuição dos valores de resistividade (Elis, 1998). Entretanto a porosidade também se revela muito importante, pois a grande maioria das rochas tem porosidade, independente do grau, e estes espaços podem estar preenchidos por eletrólitos. Como exemplo pode-se citar as rochas cristalinas, como o granito e o xisto, que possuem porosidade intergranular insignificante. Mas, ao longo das fraturas que podem estar preenchidas com água, se tornam rochas condutoras (Bortolozo, 2011). Com isso é notável que os valores de resistividade apresentem limites amplos, podendo assim, um mesmo valor englobar vários tipos de rocha, Figura 4.2. 


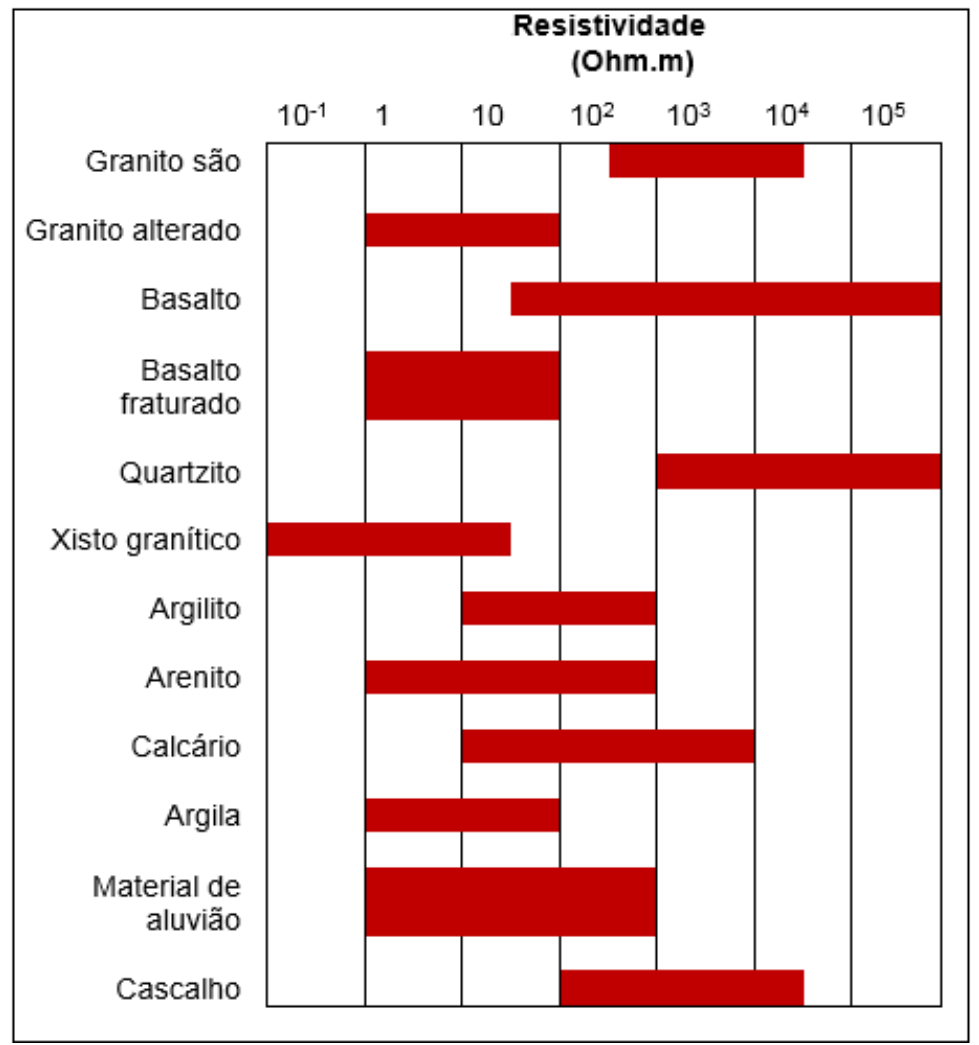

Figura 4.2: Valores das resistividades das rochas (modificado de Telford et. al, 1990)

Bortolozo, 2011 nos mostra a dedução das equações que regem os métodos elétricos.

Pela Lei de Ohm, a corrente elétrica I (Ampères, A) aplicada em um material condutor curto, fino e linear com seção transversal uniforme é dada por:

$$
I=-\frac{d V}{R}
$$

Onde $\mathrm{dV}$ é a diferença de potencial em volts (V) nas extremidades do condutor e R $(\Omega)$ é a resistência do condutor e representa um caminho particular por onde a corrente passa. Na equação 4.2, o sinal negativo significa o fato do fluxo de corrente ser na direção oposta ao gradiente, assim, caminhando no sentido do maior potencial para o menor.

Como a resistência é proporcional ao comprimento, dl, do material em metros e inversamente proporcional a seção transversal, s, em metros quadrados, temos: 


$$
\boldsymbol{R}=\boldsymbol{\rho} \frac{d l}{s}
$$

onde, a constante de proporcionalidade $\rho$ é a própria resistividade $(\Omega . m)$ do material que é uma propriedade física.

Relacionando 4.2 com 4.3 temos:

$$
I \rho \frac{d l}{s}=-d V
$$

reagrupando

$$
\frac{I}{s}=-\frac{1}{\rho} \frac{d V}{d l}
$$

Em 4.5, o lado esquerdo corresponde a densidade de corrente j dada em A. $m^{2}$. Do lado direito, -dV/dl corresponde ao campo elétrico $E\left(V \cdot m^{-1}\right)$, na direção do vetor densidade de corrente. Assim relembrando que a resistividade, $\rho$ é o inverso da condutividade, $\sigma$, podemos reescrever 4.5 como:

$$
j=\frac{E}{\rho} \leftrightarrow j=\sigma E
$$

$\mathrm{Na}$ equação 4.3, podemos fazer dl tender a zero e considerar o condutor linear como um elemento homogêneo e isotrópico (a corrente se propaga igualmente em todas as direções) de um meio contínuo, como um bloco de rocha. Assim teremos a equação 4.6 expressando a lei de Ohm para este meio. Com isso, concluise que num meio isotrópico $\rho$ e $\sigma$ são independentes do fluxo de corrente.

A injeção de corrente num meio homogêneo e isotrópico é feita através de um eletrodo em superfície. Com o comportamento da corrente em formato de uma semiesférica de raio $r$ e espessura dr. Assim, no envoltório da semiesfera, qualquer ponto vai estar a mesma distância $r$ do ponto de injeção de corrente. Conforme visto na Figura 4.3: 


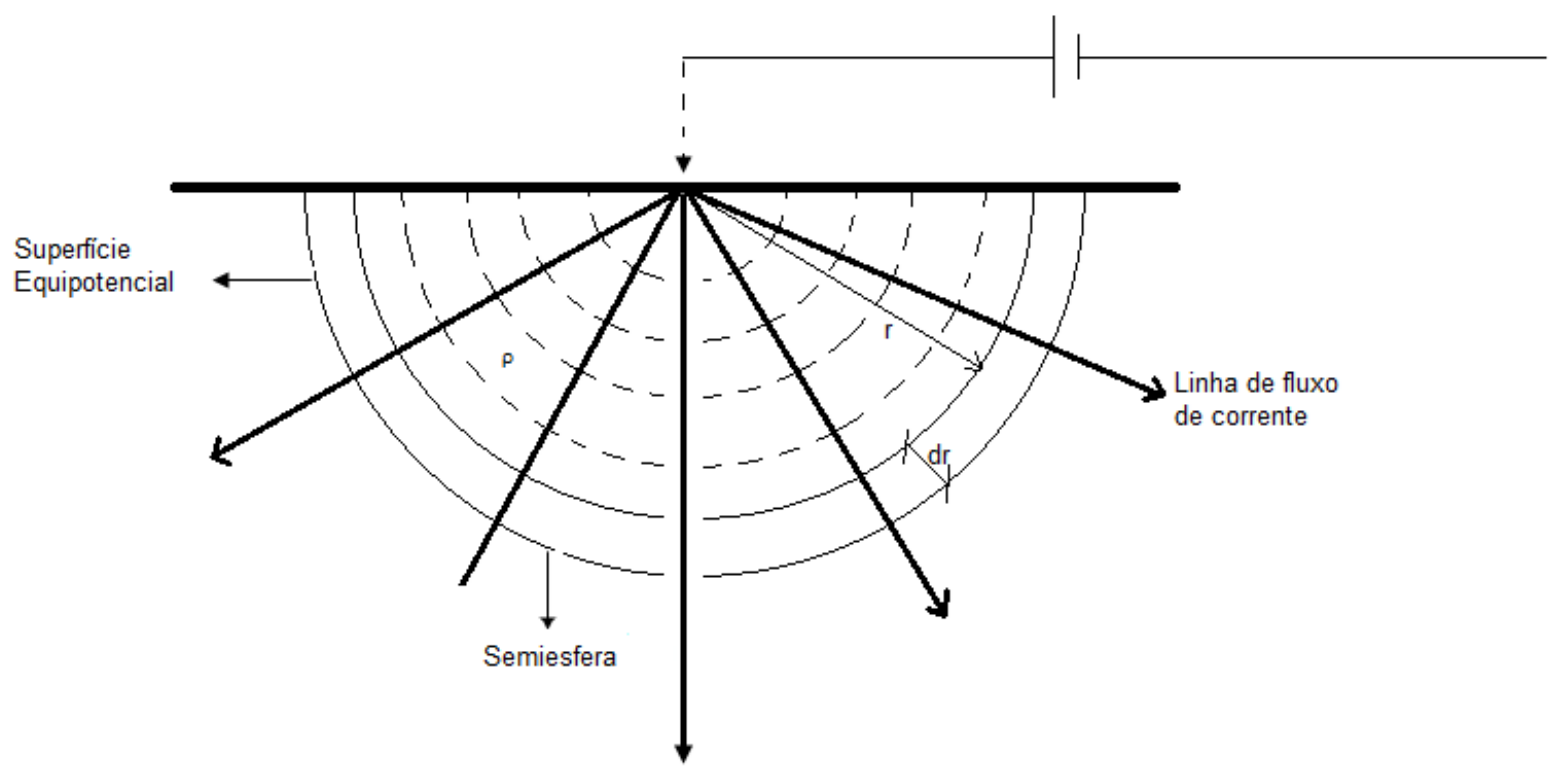

Figura 4.3: Dispersão da corrente elétrica em um meio homogêneo e isotrópico (adaptado de Bortolozo,2011).

Se a corrente total injetada pelo eletrodo é I, a diferença infinitesimal entre as faces da semiesfera é relacionada pela equação 4.7:

$$
d V=-\frac{I \rho d r}{2 \pi r^{2}}
$$

Integrando 4.7,

$$
V(r)=\frac{I \rho}{2 \pi r} \frac{1}{r}+C
$$

A equação 4.8 representa o potencial da fonte do corrente a uma distância $r$, onde $\mathrm{C}$ é uma constante arbitrária. Caso $\mathrm{V}$ tenda a zero com $r$ tendendo a infinito, teremos $\mathrm{C}$ tendendo à zero. Como isso acontece na maioria dos casos, podemos reescrever 4.8 como:

$$
V(r)=\frac{I \rho}{2 \pi r}
$$

A equação 4.9 representa o potencial de uma fonte de corrente, através de um eletrodo, a uma distância $r$ deste eletrodo. Entretanto, na prática, utilizamos dois eletrodos de corrente e dois eletrodos de potencial, para fechar o circuito. Com isso é necessário deduzir a fórmula do fluxo de corrente para este novo arranjo. 
Nesta configuração, a corrente flui do eletrodo de corrente positiva, A para o eletrodo com corrente negativa, B. O potencial em qualquer ponto $P$ na superfície pode ser calculado pela equação 2.9, onde $r_{A}$ e $r_{B}$ representam a distância do ponto $\mathrm{P}$ ao eletrodo $\mathrm{A}$ e ao eletrodo $\mathrm{B}$, respectivamente.

$$
V_{p}=\frac{I \rho}{2 \pi r_{A}}+\left(-\frac{I \rho}{2 \pi r_{B}}\right)
$$

De maneira análoga a 4.10, podemos utilizar a fórmula geral 4.9 e calcular o potencial para os eletrodos de potencial $\mathrm{M}$ e $\mathrm{N}$.

$$
V_{M}=\frac{I \rho}{2 \pi}\left(\frac{1}{r_{A M}}-\frac{1}{r_{B M}}\right)
$$

e,

$$
V_{N}=\frac{I \rho}{2 \pi}\left(\frac{1}{r_{A N}}-\frac{1}{r_{B N}}\right)
$$

Como $\mathrm{r}_{\mathrm{AM}}$ e $\mathrm{r}_{\mathrm{BM}}$, representam respectivamente a distância entre os eletrodos $A$ e $M$ e $B$ e $M$, respectivamente para $r_{A N}$ e $r_{B N}$; utiliza-se apenas $A M, B M, A N$ e $B N$ para simplificar a notação das equações. Assim teremos:

$$
V_{M}=\frac{I \rho}{2 \pi}\left(\frac{1}{A M}-\frac{1}{B M}\right)
$$

e

$$
V_{N}=\frac{I \rho}{2 \pi}\left(\frac{1}{A N}-\frac{1}{B N}\right)
$$

Assim, unificando as equações 4.13 e 4.14 , obteremos a diferença de potencial $\Delta \mathrm{V}$ entre os eletrodos.

$$
\Delta V=\frac{I \rho}{2 \pi}\left(\frac{1}{A M}-\frac{1}{B M}-\frac{1}{A N}+\frac{1}{B N}\right)
$$

$\mathrm{Na}$ prática queremos calcular a resistividade $\rho$. Para isso rearranjaremos a equação 4.15 e chamaremos a expressão entre parênteses de K. Onde K é a constante geométrica do meio, uma vez que só depende das distâncias entre os eletrodos. Com isso, teremos: 


$$
\rho=K \frac{\Delta V}{I}
$$

e

$$
K=2 \pi\left(\frac{1}{\overline{A M}}-\frac{1}{\overline{B M}}-\frac{1}{\overline{A N}}+\frac{1}{\overline{B N}}\right)^{-1}
$$

\subsubsection{A resistividade aparente}

Na prática, se utilizarmos a fórmula 4.16 para calcular a resistividade elétrica no campo, cometeríamos um erro. Isto acontece, pois ao deduzir a equação 4.16 consideramos a Terra como um meio homogêneo e isotrópico. Fato que não corresponde com a realidade, pois a Terra é heterogênea. Assim, para consideramos este fato, devemos reescrever a equação 4.16 substituindo a resistividade $\rho$ pela resistividade aparente $\rho_{a}$.

$$
\rho_{a}=K \frac{\Delta V}{I}
$$

A resistividade aparente representa o potencial medido pelos eletrodos $M N$ em um meio heterogêneo. Ao injetar corrente no subsolo, através dos eletrodos $A B$, o fluxo de corrente passa por várias camadas de resistividades diferentes. Assim, o potencial medido equivale à passagem da corrente por um meio de resistividade $\rho_{\mathrm{a}}$. Com isso a resistividade calculada não está ligada apenas a uma camada, mas a todas as camadas do pacote medido, uma vez que a corrente passou por todas elas. Sendo assim, nas equações sempre denota-se a resistividade como resistividade aparente.

\subsubsection{Técnicas de Investigação}

A escolha da técnica de investigação depende do objetivo do ensaio de campo. Caso se queira investigar a variação lateral da resistividade, logo uma investigação 2D, deve-se utilizar a técnica do caminhamento elétrico (CE). Caso, o objetivo seja a variação da resistividade em profundidade, logo uma investigação 1D, utiliza-se a técnica da sondagem elétrica vertical (SEV). Agora, se o objetivo é a investigação em profundidade, 1D, mas dentro de um poço; utiliza-se a perfilagem elétrica (PE). A diferença física entre as técnicas de investigação esta na disposição dos eletrodos durante a aquisição dos dados, Figura 4.4. 


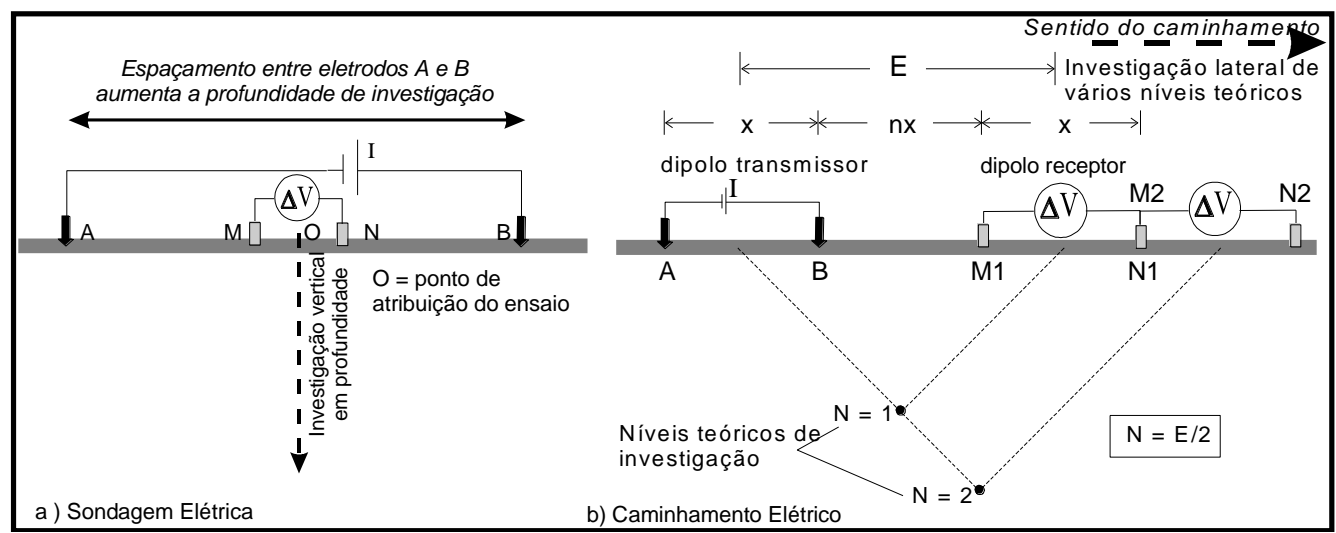

Figura 4.4: Configuração de ensaios de campo para as técnicas de Sondagem Elétrica Vertical (item a) e Caminhamento Elétrico (item b), (Retirado de Elis e Zuquette, 2000).

\subsubsection{Sondagem Elétrica Vertical (SEV)}

A técnica de sondagem elétrica vertical caracteriza-se por várias determinações de resistividade aparente em um mesmo ponto fixo, através da separação dos eletrodos de corrente e de potencial a partir de um ponto central.

Os valores de resistividade aparente são representados em função da distância $A B$ em um gráfico bilogarítmico denominado curva de sondagem elétrica. Utiliza-se este tipo de gráfico pois este permite à representação de variações de grande amplitude das grandezas e mantem as formas das curvas independentemente da normalização das grandezas. Assim tanto a curva de campo como a curva teórica podem ser comparadas por sobreposição (Santos, 2006).

Para caracterizar o meio estratificado, identifica-se na curva de sondagem elétrica vários estratos geoelétricos. O conjunto de todos os estratos geoelétricos identificáveis é denominado corte geoelétrico. Um corte geoelétrico de n camadas é representado por um conjunto de $n$ cortes geoelétricos e $n-1$ espessuras, uma vez que o fluxo de corrente não ultrapassa o último estrato (Elis, 1999). Não necessariamente um corte geoelétrico representa uma camada geológica. Uma vez que como a resistividade depende de vários fatores como a salinidade das águas intersticiais. Se uma camada geológica como um arenito, estiver parcialmente preenchida com água, em uma SEV, esta mesma camada geológica pode representar dois estratos geoelétricos. 
Os arranjos característicos para este tipo de sondagem são o arranjo Schlumberger e o arranjo Wenner. Sendo o primeiro amplamente mais utilizado que o segundo, devido a sua rapidez e menor suceptibilidade a ruídos. Embora existam ainda diversos arranjos dipolares, onde a profundidade de investigação tende a ser maior que os arranjos lineares. Entretanto este tipo de arranjo não entrará no escopo deste trabalho.

\subsection{Arranjo Schlumberger}

No arranjo Schlumberger, os eletrodos de corrente $(A, B)$ e de potencial $(M, N)$ são afastados linearmente de um ponto central $P$, Figura 4.5. Este afastamento normalmente segue uma planilha com valores pré-estabelecidos, sendo que os eletrodos $M, N$ se afastam pouco da origem. À distância $P A, P B$ ou $A B / 2$ (mais utilizada) aumenta constantemente em escala logarítmica de modo a se ter 3 , 6 ou 10 pontos por década (Santos, 2006). Mas a distância MN deve respeitar MN $<=A B / 5$. Assim para $M N=a$ e $A B=2 L$, Orellana, 1972 demostra que 0 erro nas leituras fica em torno de $4 \%$.

$\mathrm{Na}$ prática, aumenta-se $\mathrm{MN}$ quando o sinal de $\Delta \mathrm{V}$ torna-se muito fraco. Assim adota-se uma posição $A B$ e faz-se duas medidas com diferentes MN. Este tipo de procedimento denomina-se "embreagem". A embreagem permite checar em tempo real, a qualidade dos dados e verificar se a medida sofreu efeitos de heterogeneidades laterais em camadas superficiais. Assim caso o valor destoe muito, repete-se a leitura.

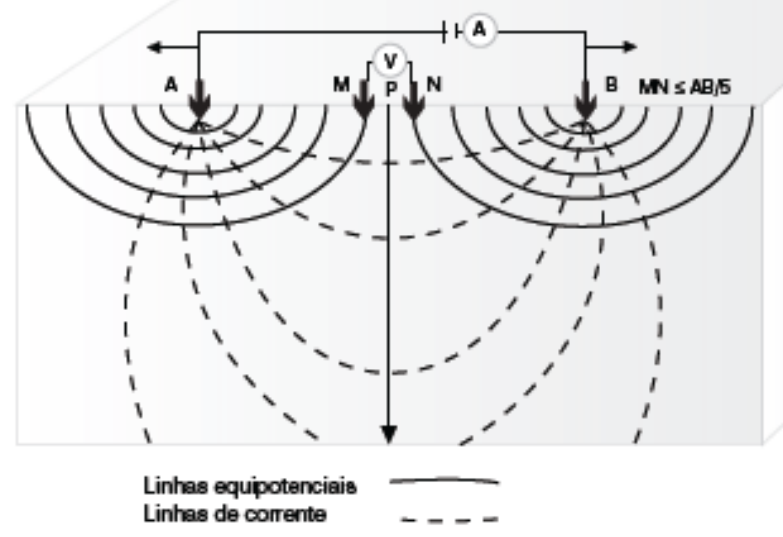

Figura 4.5.: Esquema de campo para o arranjo Schlumberger (Malagutti e Silva, 2009)

Como observado na Figura 4.5, os pontos de sondagem localizam-se no centro geométrico do arranjo. A profundidade alcançada depende de diversos 
fatores, não sendo fácil de ser calculada. O trabalho Roy \& Apparao, 1971 (apud Elis, 1999) calcula através de estudos sobre o comportamento do campo elétrico onde a profundidade máxima investigada em terrenos homogêneos é dada pela equação 4.19.

$$
h=0,125 A B
$$

A resistividade é calculada pela equação já mencionada 4.16.

$$
\rho_{a}=K \frac{\Delta V}{I}
$$

Neste caso onde,

$\rho_{a}=$ resistividade elétrica em $\Omega . m$

$\Delta \mathrm{V}=$ diferença de potencial entre os eletrodos $\mathrm{M}$ e $\mathrm{N}$

$\mathrm{I}=$ corrente que passa entre os eletrodos A e B

$\mathrm{K}=$ fator geométrico dado por

$$
K=\frac{\pi}{2}\left[\left(\frac{A B}{2}\right)^{2}-\left(\frac{M N}{2}\right)^{2}\right] \cdot\left(\frac{M N}{2}\right)^{-1}
$$

Segundo Orellana (1972), o erro produzido por esse tipo de arranjo nos dados de campo, pode ser considerado insignificante.

\subsection{Arranjo Wenner}

$O$ arranjo Wenner é muito parecido com o arranjo Schlumberger. Utiliza dois eletrodos de corrente $A B$ e dois eletrodos de potencial $M N$ linearmente dispostos. $A$ diferença está na distância relativa entre eles. Pois no arranjo Wenner a distância entre os eletrodos é a mesma, denominada a. A cada novo conjunto de leitura, todos os eletrodos são afastados do centro do arranjo $O$, mas mantendo sempre à distância a entre eles, Figura 4.6. 


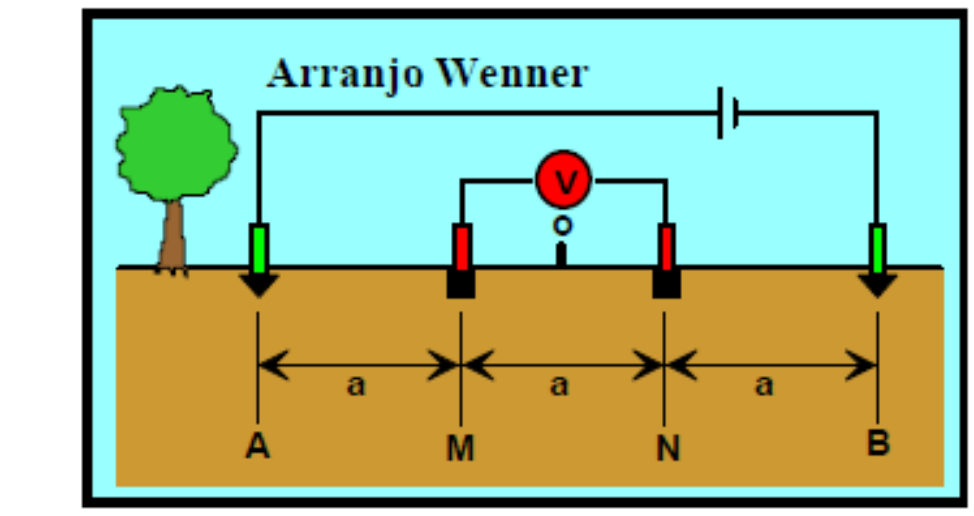

Figura 4.6: Esquema de campo para o arranjo Wenner (Braga 1999)

Com essa mudança na distância entre os eletrodos, a fórmula da resistividade aparente também muda. Ela é dada pela fórmula 4.22 , onde os parâmetros são os mesmos do arranjo Schlumberger, exceto por $\mathrm{K}$ que foi substituído pela distância reativa entre os eletrodos, a.

$$
\rho_{a}=2 \pi a \cdot \frac{\Delta V}{I}
$$

Como no arranjo Schlumberger o ponto de sondagem é o meio do arranjo O, Roy \& Apparao 1971 calcularam a profundidade de investigação para este arranjo dada pela equação 4.23 .

$$
h=0,11 A B
$$

Uma grande desvantagem do arranjo Wenner é que como todos os eletrodos se movimentam juntos, não é possível realizar a embreagem.

\subsubsection{Polarização Induzida (IP)}

A polarização induzida ou Induced Polarization (IP) é um fenômeno elétrico estimulado por corrente elétrica artificial. Em alguns materiais geológicos, quando a corrente elétrica para de atravessar um determinado material, o campo elétrico produzido pela passagem de corrente não cessa totalmente, mas vai diminuindo lentamente. Este fenômeno é conhecido como polarização induzida ou residual.

Segundo Sumner, 1976 a principal causa do fenõmeno IP em rochas mineralizadas é a corrente induzida por reação de transferência de elétrons entre íons de eletrólitos e minerais metálicos. Quando minerais metálicos bloqueam ou 
estão próximos do caminho de um poro preenchido e uma corrente elétrica flui através da rocha que contem esses poros, uma sobretensão eletroquímica acumulase na interface entre o mineral condutor e a solução no poro. Esta força eletroquimica que se opõe ao fluxo de corrente é descrita como polarização de interface e o aumento da tensão necessária para conduzir a corrente através da interface é chamado de sobretensão (overvoltage). A maior parte da corrente elétrica que passa por rochas não mineralizadas é transportada por água em fraturas e poros preenchidos pois os minerais das rochas adjacentes são isolantes eficientes.

Na prática mede-se a variação da voltagem no domínio do tempo ou no domínio da frequência. Em Orellana, 1972, a polarização induzida acontece ao passar corrente elétrica em um eletrólito que contenha metais, consequentemente que apresente condutividade eletrônica. Aplicando uma corrente constante I, durante alguns segundos através dos eletrodos de corrente $A$ e $B$ em um local onde exista um corpo condutor, presume-se que este corpo armazene energia em várias formas como, mecânica, elétrica e química. Estudos mostram que a energia química é a mais importante entre elas (Elis, 1998). Ao cortarmos a corrente a diferença de potencial $\Delta \mathrm{V}$ entre os eletrodos de potencial $\mathrm{M}, \mathrm{N}$ não desaparece bruscamente, mas é atenuada gradualmente durante alguns segundos.

Não existe um consenso sobre todos os fenômenos envolvidos na polarização induzida. Mas a literatura nos mostra que se pode distinguir duas possíveis origens para a polarização induzida. É importante ressaltar que ambos os efeitos são indistinguíveis nas medições de campo.

\subsection{Polarização de Eletrodo}

A polarização de eletrodo também é conhecida como Polarização Metálica, Polarização Eletrolítica ou Sobrevoltagem.

Este tipo de polarização ocorre devido à passagem elétrica em uma superfície de um corpo ou de uma partícula metálica. Com isso a condução iônica passa a ser eletrônica e vice -versa. Assim as superfícies do corpo se polarizam opostamente (Telford, 1990). 
Quando a corrente é cortada, os íons voltam ao seu estado original. Passando assim um certo intervalo de tempo onde o corpo esta polarizado e onde podemos mensurar o valor da polarização através da cargabilidade $M$. A intensidade da cargabilidade é inversamente proporcional a continuidade elétrica entre os grãos minerais, isto , mineralizações finamente disseminadas (Telford, 1990).

\subsection{Polarização de Membrana}

Este fenômeno aparece em rochas com ausência de minerais metálicos, devido a diferença de mobilidade entre cátions e ânions produzida pela presença de minerais de argila. Com a passagem de corrente elétrica, os argilo minerais se carregam negativamente e atraem cátions. Assim, com a passagem da corrente apenas os íons positivos fluem livremente, enquanto os negativos se concentram criando um efeito de membrana.

Ao cessar a corrente, essas barreiras catiônicas não desaparece rapidamente, originando uma sobretensão residual (Telford, 1990).

As medidas de polarização induzida são realizadas de forma muito semelhante às medidas de resistividade independente da técnica geoelétrica utilizada. Assim os aparelhos que adquirem os dados de resistividade também medem os efeitos de IP, independente de o domínio ser no tempo ou na frequência.

\subsection{IP - Domínio do tempo}

Tanto na polarização de membrana quanto na polarização eletrolítica, ao cessar a corrente cria-se uma diferença de potencial variando no tempo em forma de uma curva $\Delta V_{\mathbb{P}}=f(t)$. $A$ amplitude da curva de $\Delta V_{\mathbb{P}}$ esta ligada à maior ou menor capacidade de polarização do meio. Esta capacidade de polarização constitui a susceptibilidade IP dos materiais geológicos.

No IP- Domínio do tempo, a curva de $\Delta \mathrm{V}_{\mathrm{IP}}$ é conhecida como curva de descarga, pois se faz uma analogia como se o solo tivesse pequenos condensadores que se carregam com a passagem de corrente e se descarregam após o fim da passagem de corrente. Esta curva é o objetivo de estudo do método. Ela pode ser analisada em sua totalidade ou ser discretizada em intervalos menores, Figura 4.7. 


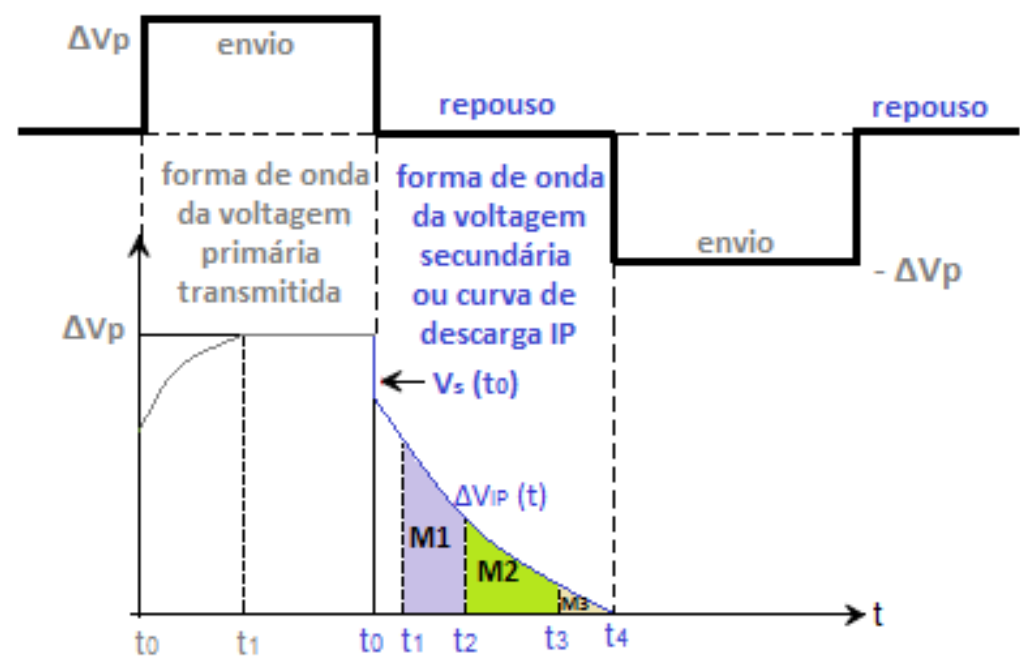

Figura 4.7: Curva de descarga de IP no domínio do tempo (modificado de Braga, 1999).

Como citado anteriormente, o parâmetro medido é a cargabilidade $\mathrm{M}$ e normalmente é expresso em miliVolt/Volt (mV.s/V). Mas, como acontece com a resistividade, na prática mede-se a cargabilidade aparente, pois as camadas em subsuperfície são heterogêneas, fórmula 4.24 .

$$
M=\frac{\Delta V_{I P} \cdot \mathbf{1 0 0 0}}{\Delta V_{P}}(\mathrm{t})
$$

onde $\Delta \mathrm{V}_{\mathrm{IP}}$ é a diferença de potencial medida.

\subsection{IP- Domínio da frequência}

No domínio da frequência, assume-se que o campo eletromagnético é simples como uma vibração harmônica e a corrente de deslocamento entre o ar e o meio é negligenciada. (Yong, Li, 2011).

Existem dois modelos matemáticos teóricos para calcular o IP no domínio da frequência. O primeiro é o método de Cole-Cole que é utilizado para calcular o efeito IP nas rochas e nos minerais. O outro modelo é conhecido como "o método de cálculo teórico" que utiliza uma fórmula muito mais complexa que Cole-Cole. Este método é utilizado quando o modelo de terra homogênia ou estratificada apresenta polarização condutora. Assim, a incógnita de resistividade usada por Cole-Cole toma o lugar da resistividade do meio de condução na expressão do método de cálculo teórico. 
No IP domínio da frequência, os dados podem ser de duas maneiras:

1) Dados com unidades conhecidas como "Percent Frequency Effect" (PFE) que requerem que a resposta seja medida em duas frequências diferentes, altas e baixas.

2) Os dados com unidade de fase são adquiridos pela manutenção da sincronia entre a onda sinoidal transmitida e o sinal recebido. Logo, a diferença de fase entre a fonte e o sinal é registrado como uma medida de cargabilidade utilizando como unidade o mili-radiano.

De acordo com Telford, 1990, a grande desvantagem de se obter dados de IP no domínio da frequência em relação ao domínio do tempo é a velocidade de aquisição dos dados. Pois no domínio da frequência há a necessidade de se obter duas frequências bem amostradas. Além do fato que ao adquirir dados no domínio da frequência, a corrente deve ser ajustada com uma grande precisão.

\subsubsection{Caminhamento Elétrico (CE)}

A técnica do caminhamento elétrico consiste em obter uma variação lateral de resistividade a profundidades constantes a partir de medidas efetuadas na superfície do terreno fixando os eletrodos de corrente e caminhando com os eletrodos de potencial. Calculando a cada passo a diferença de potencial $\Delta \mathrm{V}$ gerada pela passagem de corrente I pelo terreno. Uma vez que os eletrodos apresentam a mesma distancia relativa entre eles.

A resistividade medida também é a resistividade aparente, pois a subsuperfície não apresenta apenas camadas homogêneas. A resistividade aparente é dada pela fórmula 4.25 .

$$
\rho=K \frac{\Delta V}{I}
$$

Os resultados são geralmente apresentados em pseudoseções, quando se tem várias profundidades determinadas e vários níveis de investigação. O caminhamento é aplicado quando se deseja observar variações laterais de resistividade. Assim é muito utilizado para a detecção de contatos litológicos, mudanças laterais de fácies ou estruturas como falhas e fraturas. Além de 
investigações ambientais como detecção de contaminação em aquíferos, detecção da direção e fluxo de plumas de contaminação. Em estudos aplicados a geologia de engenharia como identificação de contato entre a rocha de interesse e as rochas ao redor.

Para esta técnica existem vários tipos de arranjo, como o Schlumberger e o Wenner já descritos. Entretanto os arranjos mais utilizados são os dipolares como: dipolo-dipolo, polo-polo, polo-dipolo e dipolo-polo. $\mathrm{O}$ arranjo dipolo-dipolo é um dos mais precisos e rápidos de ser executado no campo para ensaios de caminhamento elétrico. Além desse arranjo, os arranjos polo-dipolo e dipolo-polo são bastante utilizados.

\subsection{Arranjo dipolo-dipolo}

O arranjo dipolo-dipolo utiliza no mínimo quatro eletrodos, dois de corrente $(A B)$ e no mínimo dois de potencial (MN) dispostos segundo um mesmo perfil. Estes eletrodos ficam espaçados $X=A B=M N$. As medidas são efetuadas em vários níveis de investigação, onde cada par de eletrodos $\mathrm{MN}$ corresponde a um nível denotado por $n=1,2,3,4, \ldots$. Estes níveis são atribuídos a intersecção das linhas que partem dos centros dos eletrodos $A B$ e $M N$ em ângulos de $45^{\circ}$, Figura 4.8. Braga, 2006, mostra que, para alguns autores, a profundidade teórica atingida no arranjo dipolo-dipolo é igual a $Z$ = R/2 (metros), onde $R$ é a distância entre os centros dos dipolos $A B$ e $M N$.

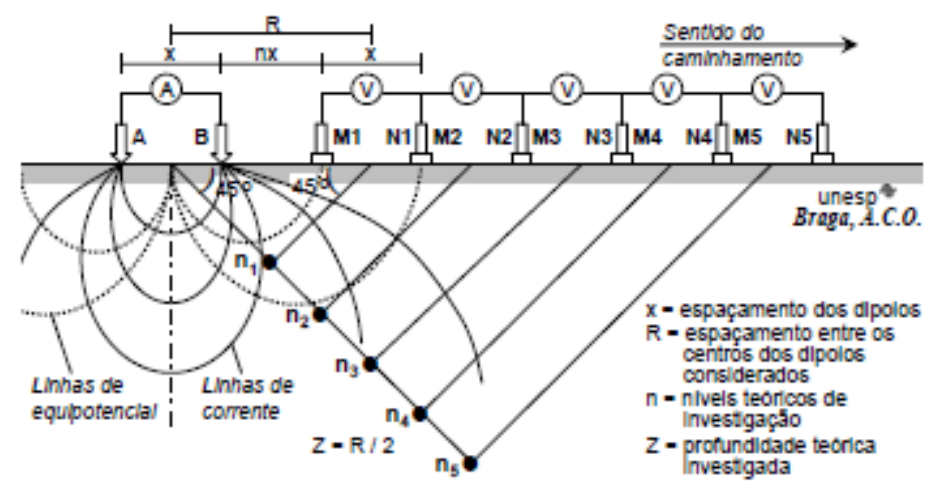

Figura 4.8: Arranjo dipolo-dipolo (Braga, 2006)

Para este tipo de arranjo, a resistividade aparente também é dada pela equação 4.16. Entretanto como o fator geométrico $\mathrm{K}$ depende da disposição dos 
eletrodos, neste tipo de arranjo ele é calculado pela equação 4.27 e 4.2 .8 (Braga, 2006).

$$
K=2 \pi \cdot G \cdot X
$$

onde

$$
G=\frac{1}{\frac{1}{n}-\frac{2}{n+1}+\frac{1}{n+2}}
$$

Um efeito de ruído bastante comum neste tipo de arranjo é a aparição de flancos anômalos nas pseudoseções devido aos eletrodos de corrente e potencial estarem aterrados na superfície, criando nas estruturas geológicas um efeito estático. A intensidade dos flancos varia dependendo da geologia. Um exemplo deste tipo de ruído esta na Figura 4.9.

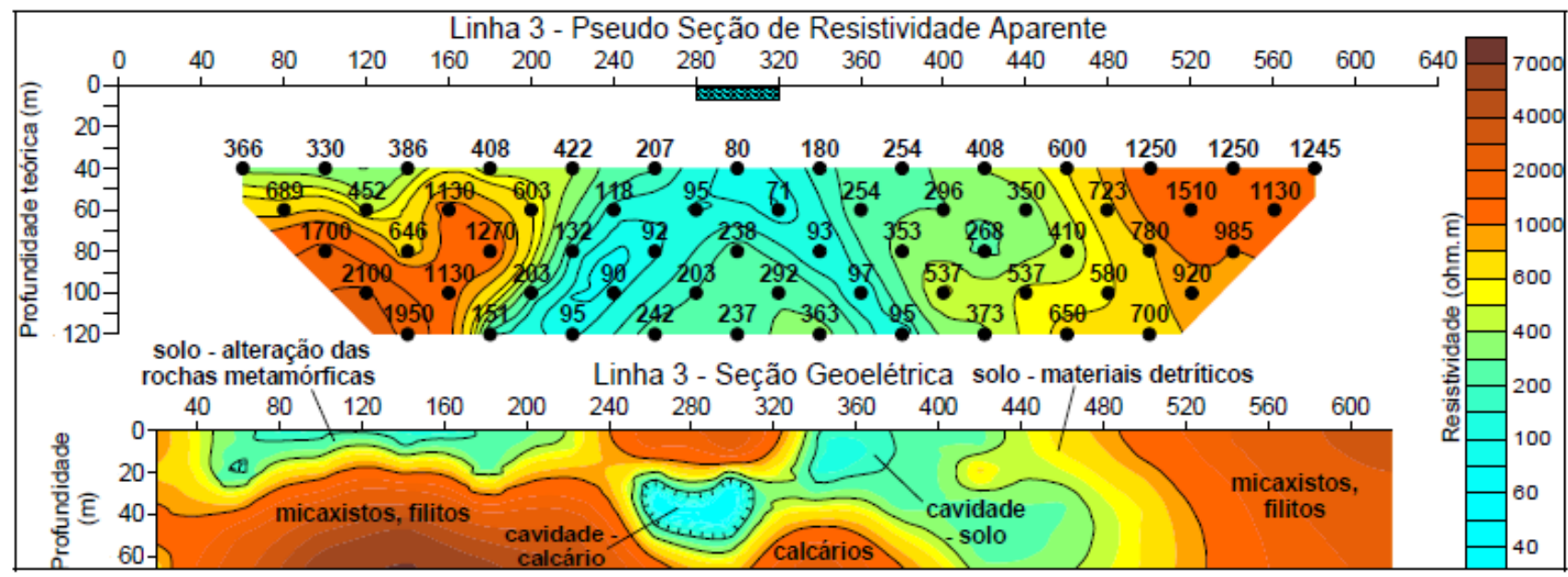

Figura 4.9: Presença da anomalia condutora em um CE com arranjo dipolo-dipolo no software Res2DInv (retirado de Braga 2006)

$\mathrm{Na}$ Figura 4.9 nota-se a anomalia condutora associada a uma falha. Segundo Braga 2006, o flanco esquerdo relaciona-se a passagem dos eletrodos de potencial sobre a falha e o flanco direito relaciona-se a passagem dos eletrodos de corrente. Este tipo de anomalias tanto condutoras como de corrente, podem ser filtradas e por vezes eliminadas no processo de tratamento dos dados.

\subsection{Arranjo Polo-Dipolo}

O arranjo polo-dipolo diferentemente do dipolo-dipolo apresenta apenas três eletrodos móveis, um eletrodo de corrente e dois eletrodos de potencial. Neste 
arranjo o eletrodo B fica fixo a uma distância bem grande, em torno de 10 a 20 vezes, dos eletrodos A, M e N, Figura 4.10. Para garantir que sua influência seja mínima. Da mesma forma que o arranjo dipolo-dipolo, o eletrodo de corrente $A$ permanece fixo enquanto os de potencial MN caminham, aumentando assim a profundidade de investigação. Após uma série, todos os eletrodos se distanciam do mesmo valor da distância relativa entre eles.

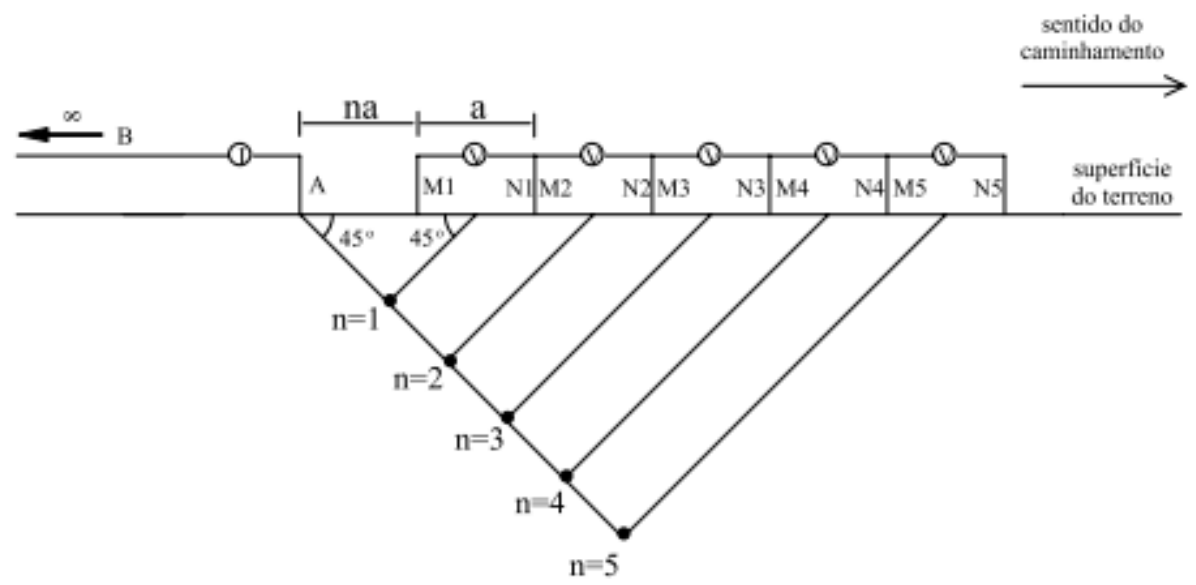

Figura 4.10: Arranjo polo-dipolo (Gandolfo e Gallas, 2007)

O cálculo da resistividade é igual ao arranjo dipolo-dipolo dado por 4.16 e o fator $\mathrm{K}$ também é igual a 4.27. O único parâmetro que se altera é G que é dado por 4.29 .

$$
G=\frac{1}{\frac{1}{n}-\frac{1}{n+1}}
$$

A pseudoseção é construída de forma análoga ao arranjo dipolo-dipolo. Estabelecendo assim a mesma relação de $45^{\circ}$ entre os centros dos eletrodos.

Gandolfo e Gallas, 2007, mostram que uma característica favorável ao arranjo polo-dipolo é que para uma mesma intensidade de corrente, o sinal recebido pelos eletrodos de potencial é mais intenso que no arranjo dipolo-dipolo.

\subsection{Arranjo Dipolo-Polo}

O arranjo dipolo-polo é uma variação do arranjo polo-dipolo. Este arranjo também apresenta apenas três eletrodos móveis, sendo dois eletrodos de corrente e um de potencial. Neste arranjo o eletrodo $\mathrm{N}$ fica fixo a uma distância em torno de 10 a 20 vezes maior que os eletrodos $A, B$ e $M$. 


\section{AQUISIÇÃO DOS DADOS}

Neste trabalho foram realizados 13 ensaios de Sondagens Elétricas Verticais (SEV) e 4 ensaios de caminhamento elétrico (CE).

\subsection{Aquisição dos dados de SEV}

Os dados de Sondagem Elétrica Vertical foram adquiridos utilizando o eletroresistivimetro Syscal R2 (Figura 5.1). Este aparelho é produzido pela Iris Instruments e constitui de uma única unidade que desempenha simultaneamente a função de transmissor e receptor, com o auxílio de uma fonte de energia externa. Este instrumento é capaz de realizar medidas simultâneas de resistividade elétrica e polarização induzida. Este aparelho precisa ser acoplado a uma fonte de alimentação e a uma bateria (Iris Instrument, 2012).

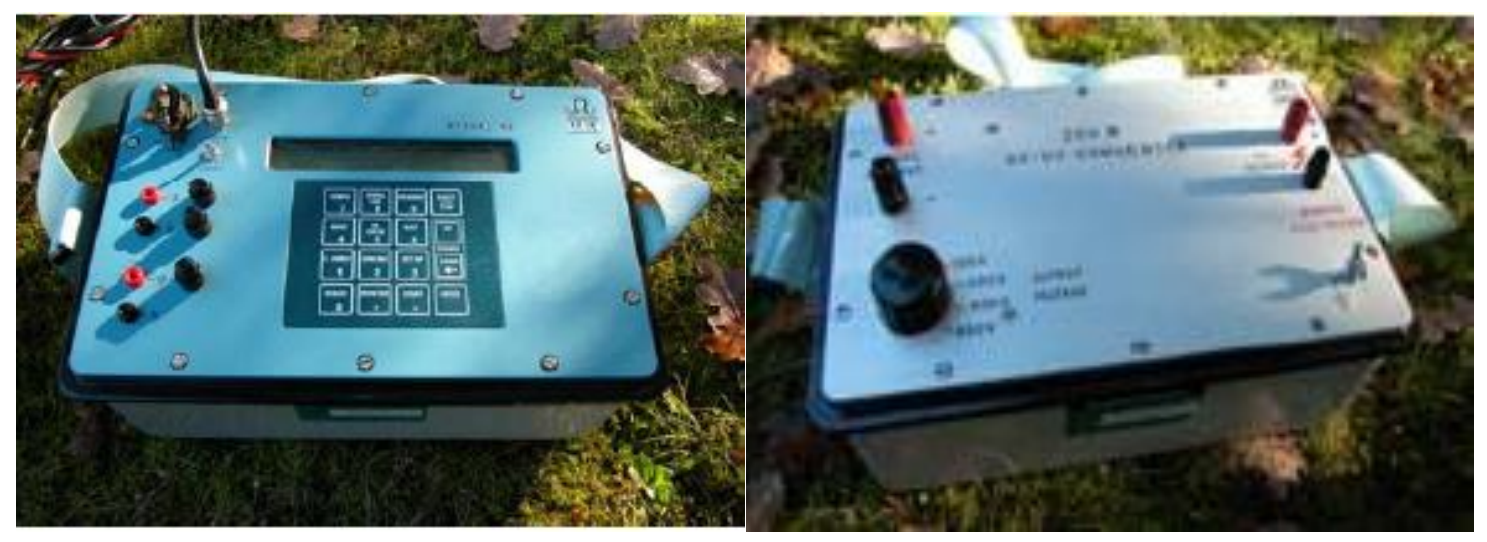

Figura 5.1: À esquerda a unidade do Syscal R2 e a direita a fonte de alimentação do Syscal.

Com este aparelho, os dados foram adquiridos principalmente na região limitrofe da pedreira, com o intuito de analisar o comportamento do gnaisse e do xisto nas regiões mais afastadas da área de lavra e verificar a viabilidade de um plano de expansão da mina pelos próximos 20 anos.

Estes equipamentos juntamente com uma bateria, foram transportados em um carrinho, o que facilitou sua mobilização durante a aquisição dos dados. A Figura 5.2 mostra esta disposição das aparelhagens. 


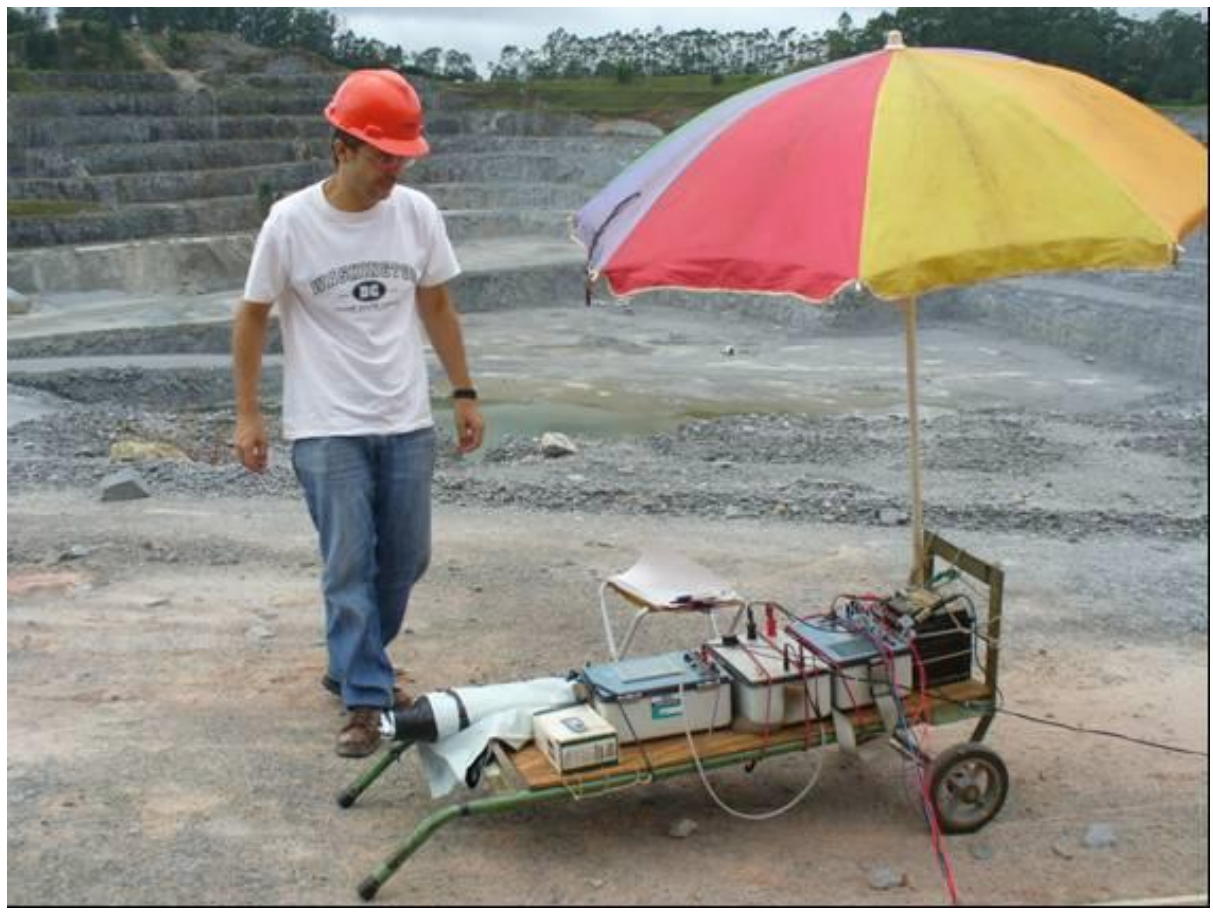

Figura 5.2: Esquema de campo levando todos os aparelhos necessários para realizar as medidas de SEV e CE.

Além destes equipamentos, utilizaram-se acessórios inerentes a qualquer trabalho de campo como trena, martelo e banco. Foram utilizados eletrodos metálicos para injetar corrente e eletrodos porosos para leituras de potencial (Figura 5.3).

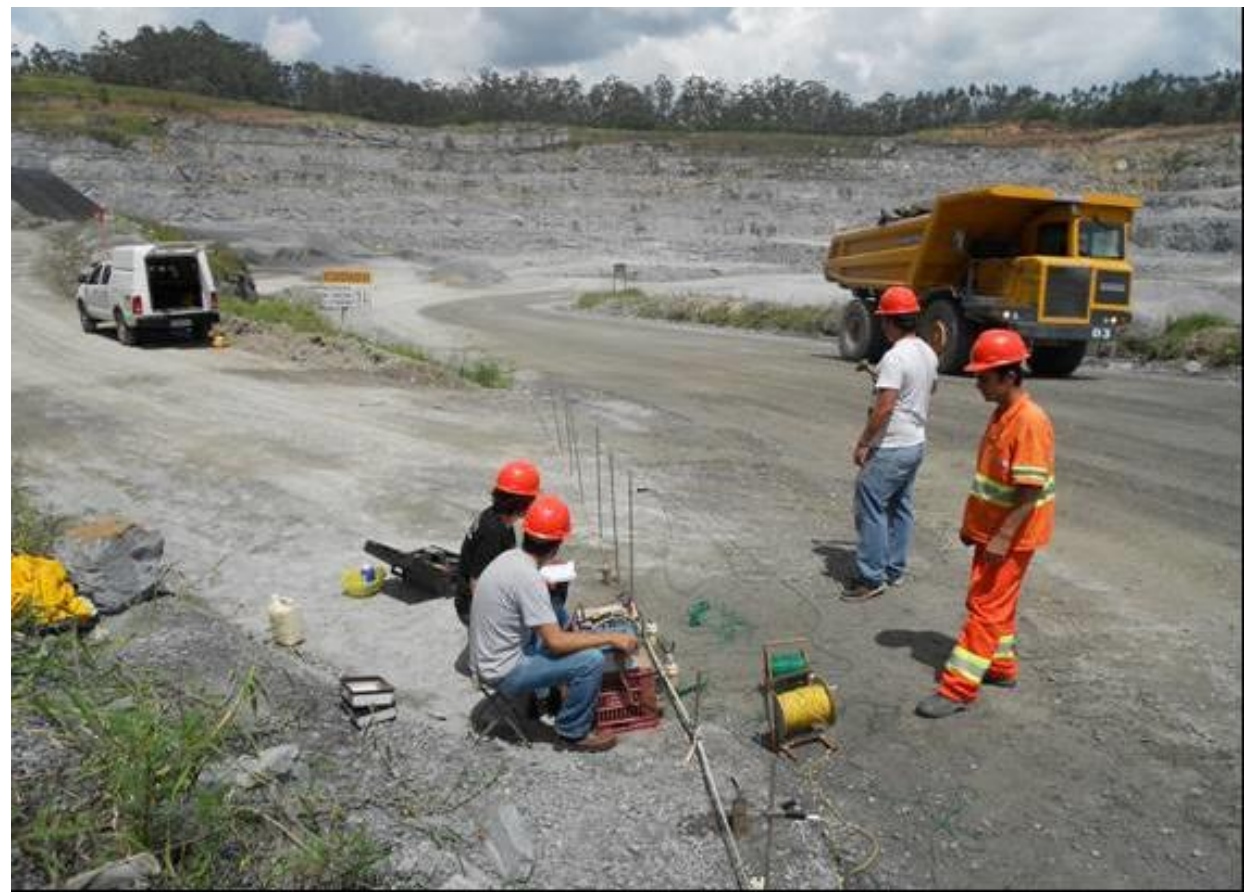

Figura 5.3: Esquema de campo mostrando os dois eletrodos porosos em frente aos equipamentos e eletrodos metálicos ao seu redor. 
Ao todo foram realizados 13 ensaios de SEV, utilizando o arranjo Schlumberger. A explicação sobre este procedimento pode ser encontrado no capítulo 4.

Os ensaios foram feitos em duas frentes de trabalho, a primeira em outubro de 2011 onde foram adquiridos as SEV's de 1 a 7 mais os 4 caminhamentos e a segunda em fevereiro de 2012 onde foram adquiridos as SEV's de 10 a 15.

\subsection{Aquisição dos dados de CE}

Os dados de caminhamento elétrico (CE) foram adquiridos também com o Syscal R2 acoplado ao receptor Elrec Pro Ten Channel Receiver, que permite a leitura de até dez dipolos adjacentes simultaneamente. Uma imagem do Elrec Pro pode ser visualizada na Figura 5.4.

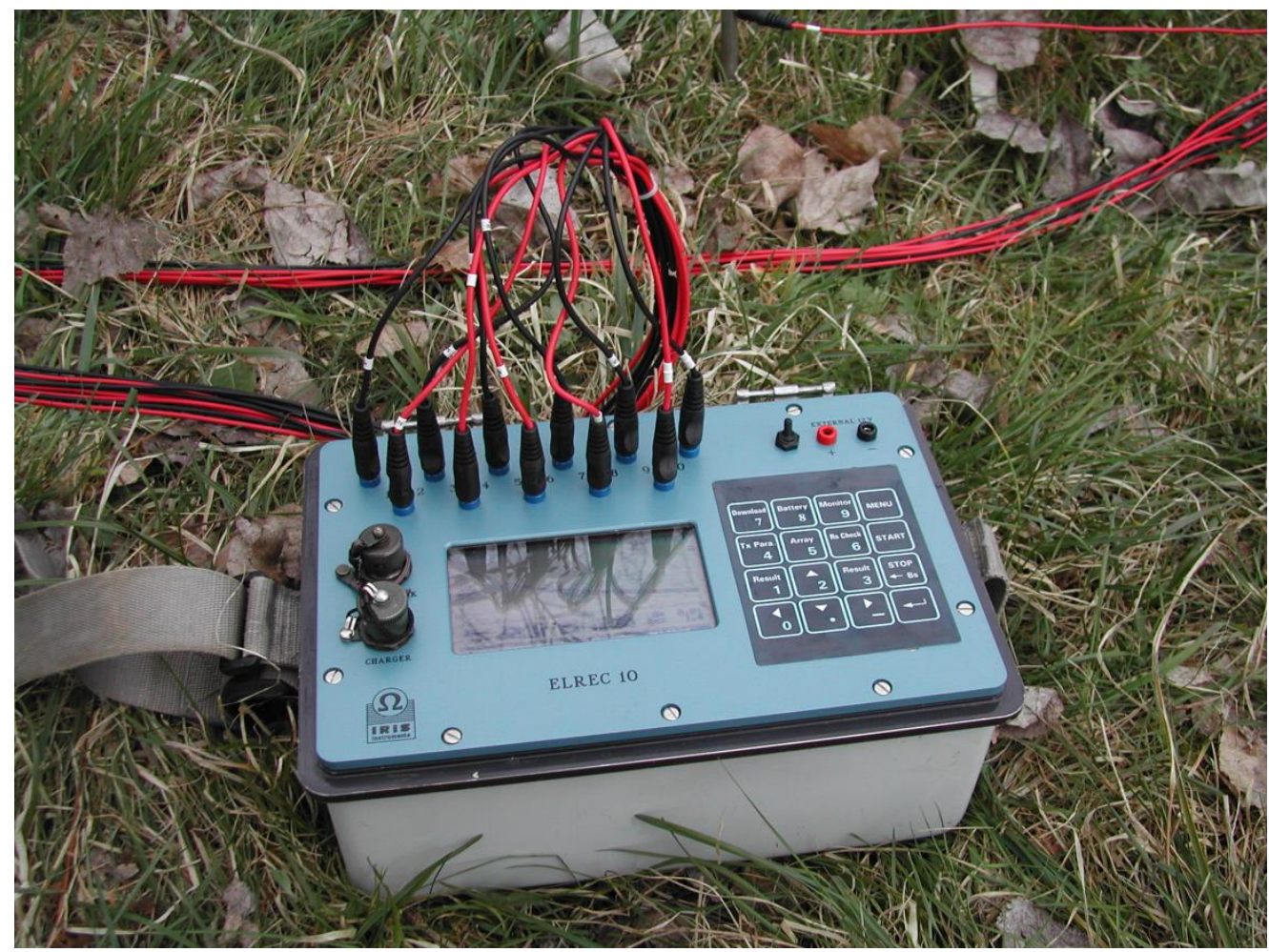

Figura 5.4: Elrec Pro Ten Channel Receiver

Nos ensaios de SEV também foram utilizado eletrodos metálicos injetando corrente além de eletrodos porosos medindo o potencial. 
Ao todo foram realizados 4 caminhamentos elétricos, todos com arranjo dipolo-dipolo, com abertura entre eletrodos de 20 metros e 6 níveis de investigação. Como já referido anteriormente, os dados de caminhamento foram coletados em outubro de 2011. 


\section{Resultados e Discussões}

\subsection{Sondagem Elétrica Vertical}

\subsubsection{Interpretação}

Os dados de Sondagem Elétrica Vertical foram interpretados no programa RESIX-IP (Interpex, 1993).

O programa RESIX-IP permite o tratamento dos dados adquiridos com arranjos Schlumberger, Wenner, polo-dipolo, dipolo-dipolo, dipolo equatorial e arranjos dipolares perpendiculares. Tem uma limitação máxima de 10 camadas para um modelo inicial e 8 camadas para a inversão. Eé um programa iterativo de modelagem direta ou inversa para interpretar dados de resistividade e polarização induzida juntos ou separadamente. Inicialmente, deve-se criar um modelo a partir do número de camadas, Figura 6.1. Este modelo inicial pode ter até 7 camadas, caso se tenha dados de RE e IP, ou até 10 camadas caso só haja um parâmetro. Durante a inversão, pode-se realizar alguns procedimentos como mascarar dados. Estes dados serão marcados com uma cruz e não serão considerados durante a inversão. Pode-se também fixar parâmetros como espessura, profundidade, resistividade ou uma combinação destes.

Após a inversão dos dados, o programa cria um modelo de camadas equivalentes e suaves para os dados de RE e IP, como pode ser visualizado no exemplo da Figura 6.2. 


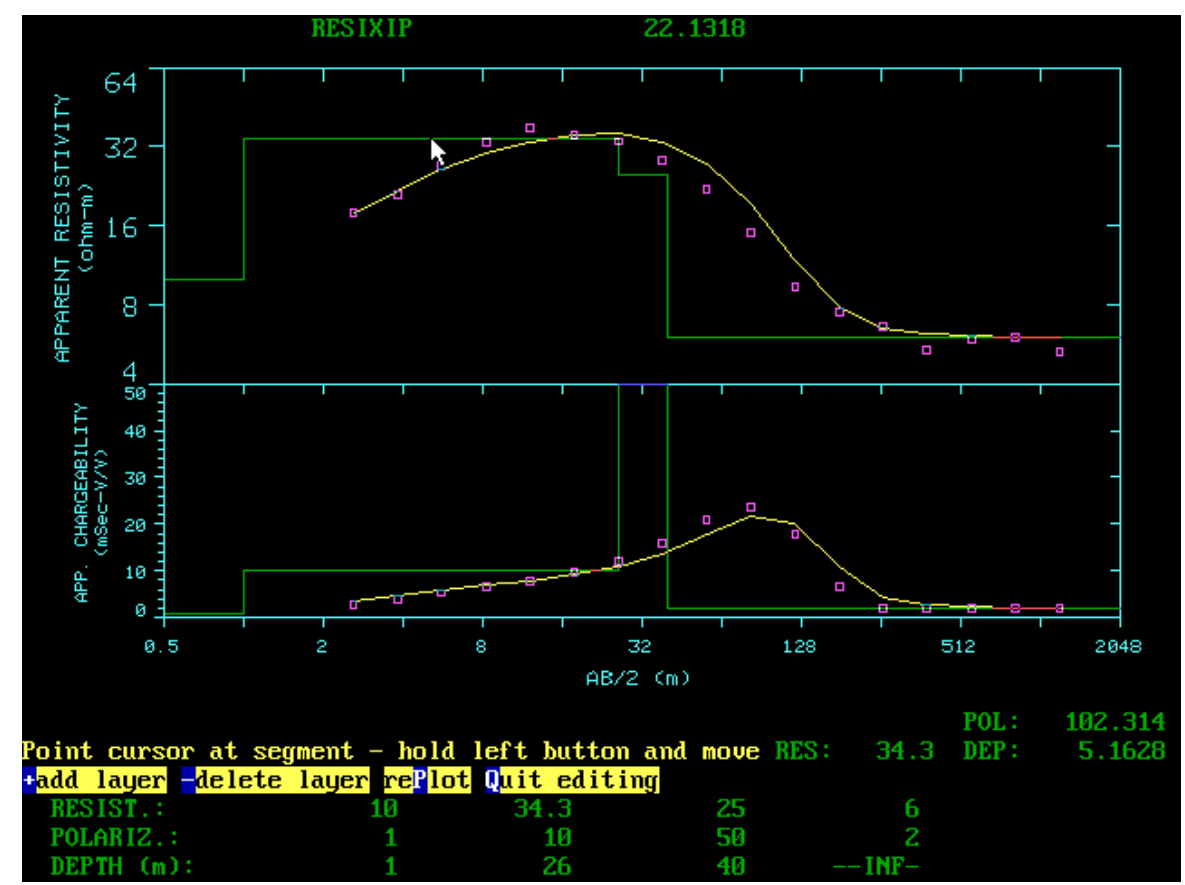

Figura 6.1: Exemplo da criação do modelo inicial para um dado com valores de resistividade e polarização induzida (Retirado do site da Interprex).

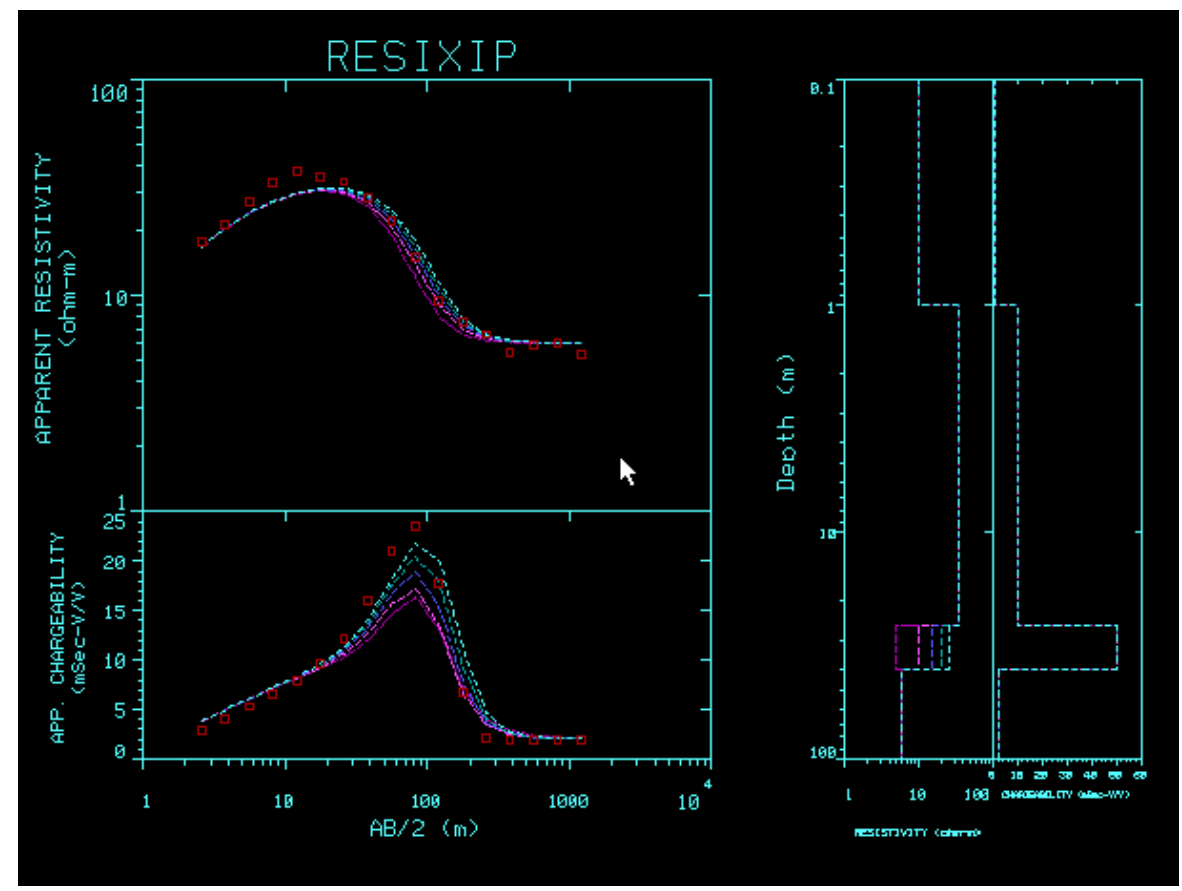

Figura 6.2: Exemplo da saída do programa para um dado com informações de resistividade e polarização induzida (Retirado do site da Interprex).

Os dados das SEVs foram coletados segundo a disposição mostrada na Figura 6.3. Observa-se que a numeração é descontínua, pois os pontos indicados para a execução das SEVs 8 e 9 não permitiam a instalação do arranjo devido a 
topografia local. Dessa forma, serão apresentados os resultados das SEVs 1 a 7 e 10 a 15. Além disso em cores esta a geologia esperada para o local, onde o rosa corresponde ao gnaisse, o azul ao xisto e o amarelo com o xisto milonitico que é uma rocha que provem da alteração do xisto. Assim pode-se considerar esse mapa como um prévio mapa geológico da pedreira Embu.

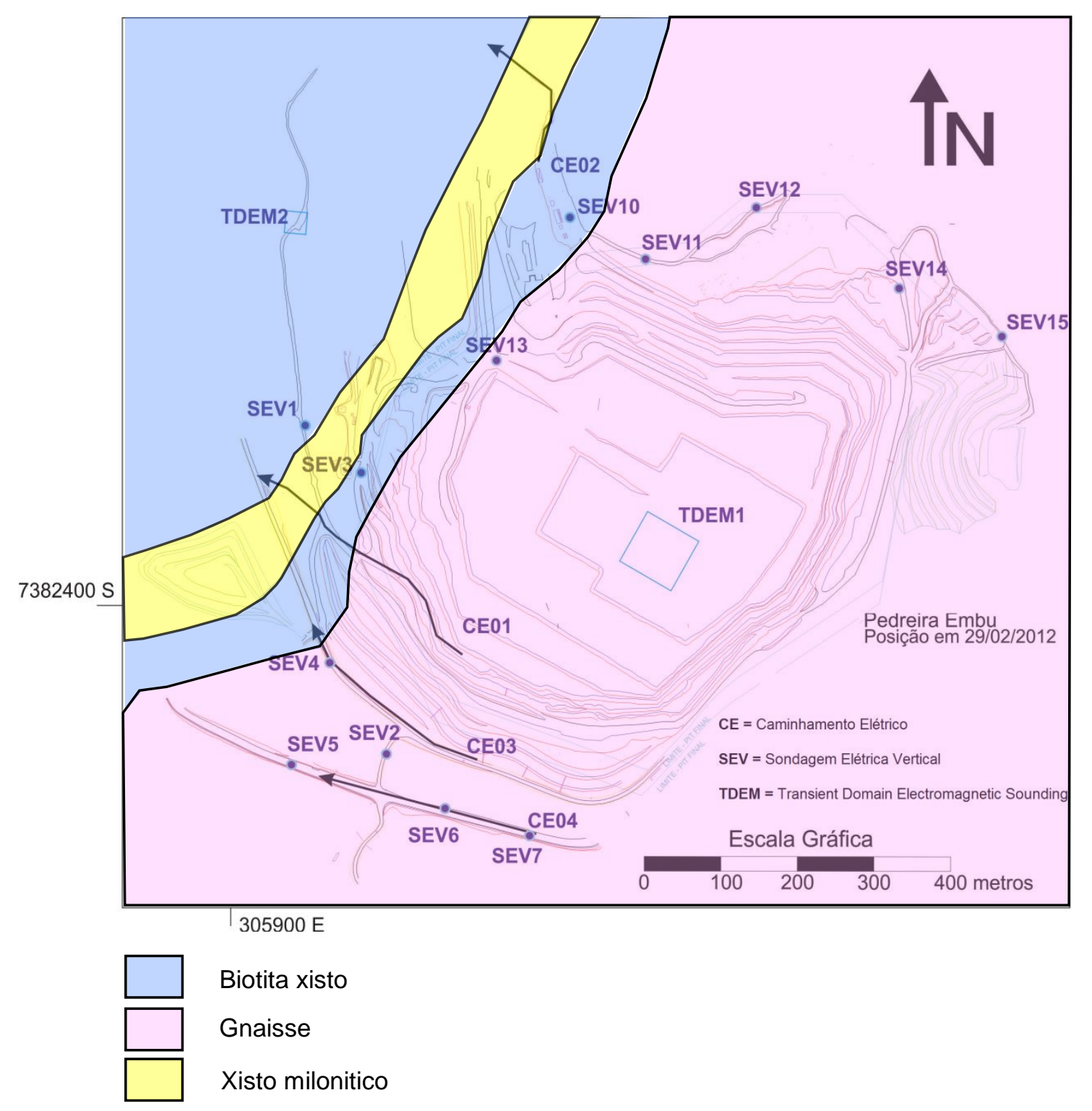

Figura 6.3: Disposição dos dados coletados, onde as setas pretas indicam o sentido dos caminhamentos elétricos.

Além da informação quanto a geologia, em trabalhos anteriores foram realizados duas sondagens de TDEM (Transient Domain ElectroMagnetic), os resultados deste trabalho estão nas Figuras 6.4 e 6.5. 

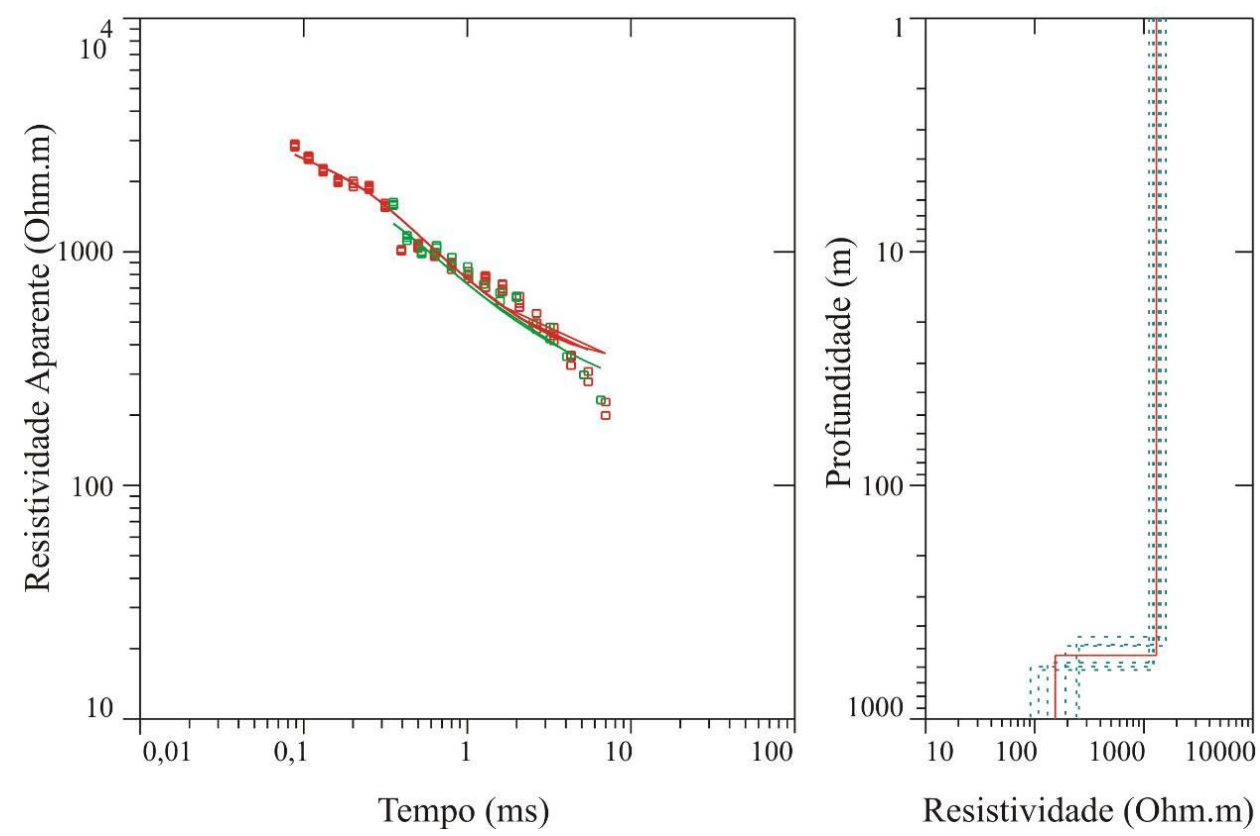

Figura 6.4: Sondagem TDEM1 no Pit da Pedreira. A esquerda os dados (pontos em vermelho e verde) e a curva do modelo de terra que melhor ajusta aos dados (linha contínua). À direita os modelos de camadas equivalentes do subsolo que se ajustam aos dados com erro menor que $20 \%$.
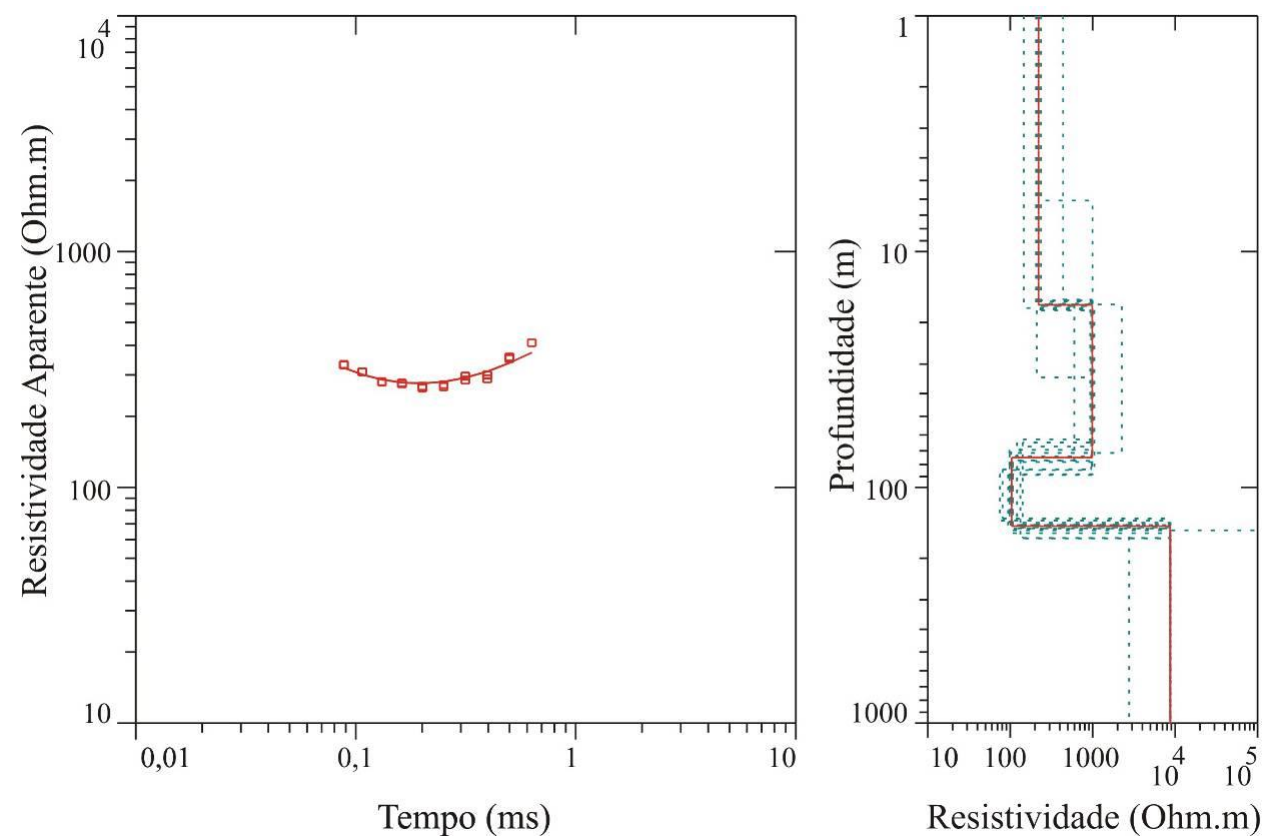

Figura 6.5: Sondagem TDEM2 no alto da Pedreira. A esquerda os dados em vermelho e a curva do modelo de terra que melhor ajusta aos dados (linha contínua). À direita, os modelos de camadas equivalentes do subsolo que se ajustam aos dados com erro menor $8 \%$. 
A sondagem TDEM1 realizada no Pit da Pedreira sugerindo que a rocha gnáissica sã tem uma espessura $\sim 400 \mathrm{~m}$. A sondagem TDEM realizada no Alto da Pedreira mostrou que o manto de alteração é da ordem de $20 \mathrm{~m}$ de espessura, e entre 20 - 70m de profundidade a rocha gnáissica é considerada sã (relatório interno).

\subsubsection{Resultados e discussões}

A partir do procedimento descrito, os dados de SEV foram interpretados. Devido a localização das SEVs, as observações de campo quanto a litologia e a disposição estrutual, além das informações obtidas em Alves (2012) a interpretação das SEVs considerou o tipo rochoso que deve aflorar no ponto de ensaio. Os valores de resistividade obtidos, especialmente para a rocha sã, em alguns pontos corroboram a interpretação geológica de Alves, 2012 e em outros redefiniram os contatos geológicos. Além disso, as informações de duas sondagens TDEM (Time Domain Eletromagnetic) são utilizadas para corroborar a interpretação geológica de que as camadas apresentam mergulho para SE. Os resultados do conjunto de dados podem ser visualizados nas Figuras de 6.6 a 6.12.

A primeira sondagem (Figura 6.6) esta localizada em uma região com substrato xistoso, que é uma rocha que dependendo do teor de umidade, apresenta resistividade baixa, em torno de 0,1 a 50 Ohm.m (Telford, 1990) e cargabilidade mais alta. Sendo assim, foi possível identificar 3 camadas: a primeira com uma resistividade em torno de $630 \mathrm{Ohm} . \mathrm{m}$ que pode ser interpretada como um solo de alteração ou rocha alterada. Já a segunda camada apresenta uma resistividade notadamente mais alta, corresponde a solo ou saprolito (rocha alterada) com os poros preenchidos por ar (não saturado). A camada inferior apresenta um resistividade em torno de 300 Ohm.m, o que nos leva a associa-la ao xisto, que portanto começa a uma profundidade de $27,57 \mathrm{~m}$ aproximadamente. É importante comentar que os modelos se ajustaram bem aos dados coletados, principalmente a curva de resistividade. 


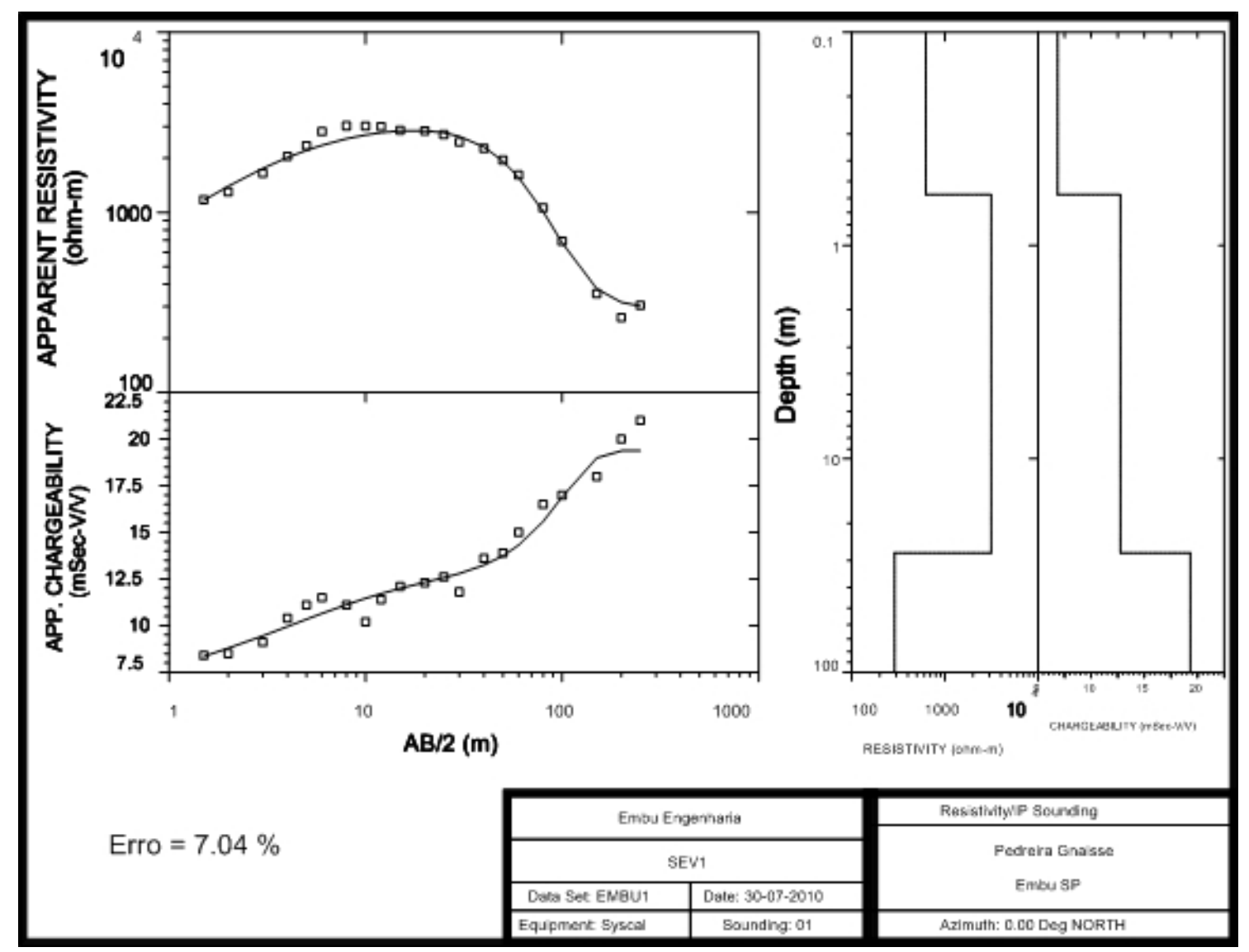

\begin{tabular}{lccc}
\hline & Camada 1 & Camada 2 & Camada 3 \\
\hline Resistividade & 625,68 & 3150,20 & 287,73 \\
Cargabilidade & 6,84 & 12,75 & 19,32 \\
Profundidade & 0,57 & 27,57 & \\
\hline
\end{tabular}

Figura 6.6: Resultado do processamento da SEV 1.

A SEV 2 encontra-se em terreno gnáissico. Os dados para esta SEV, Figura 6.7, apresentaram comportamento suave para os dados de resistividade, mas ligeiramente dispersos no final da aquisição para os dados de cargabilidade. Sendo assim, a curva de resistividade ajustou-se bem, mas como a inversão é feita conjuntamente, não foi possível ajustar a curva de cargabilidade. Logo como a confiabilidade dos dados de resistividade é maior, optou-se por mascarar os dados finais da curva de cargabilidade. Portanto na inversão esses dados mascarados não foram considerados. Assim, feito este procedimento, os dados foram invertidos e foi possível identificar 3 camadas, a primeira com uma resistividade alta e cargabilidade baixa o que nos faz associar a um solo de alteração de gnaisse. A segunda camada com uma resistividade bem alta e cargabilidade intermediária o que nos faz associa- 
la ao gnaisse inalterado. Portanto o gnaisse se encontraria a uma profundidade entre 2,33 e 14,26 metros. Por último encontra-se uma camada com uma resistividade alta, mas menor que a segunda camada e, apresenta uma cargabilidade ligeiramente maior. Assim associamos esta camada a um gnaisse fraturado.
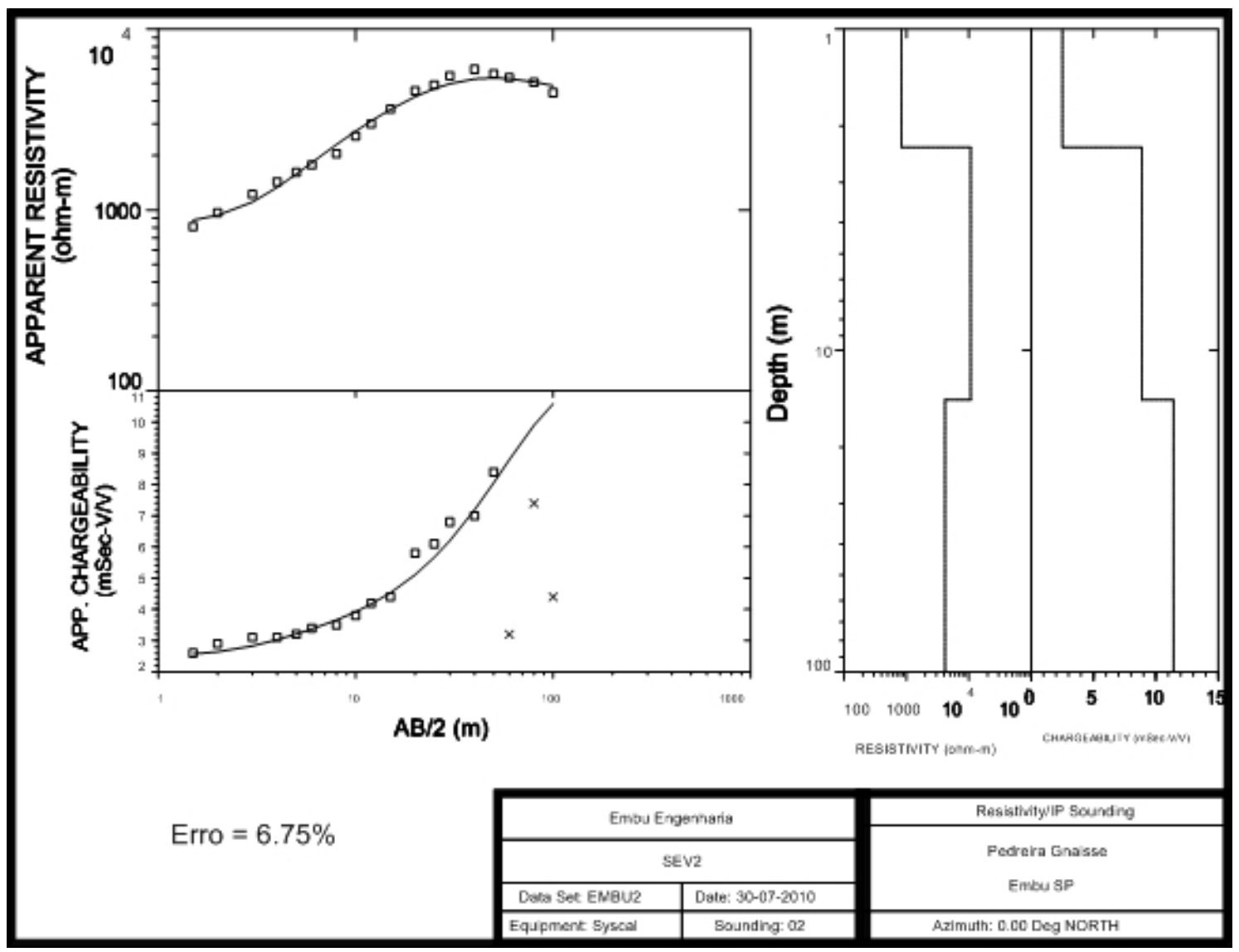

\begin{tabular}{lccc}
\hline & Camada 1 & Camada 2 & Camada 3 \\
\hline Resistividade & 832,61 & 10731,57 & 4146,94 \\
Cargabilidade & 2,51 & 8,88 & 11,43 \\
Profundidade & 2,33 & 14,26 &
\end{tabular}

Figura 6.7: Resultado do processamento da SEV 2 
A SEV 3 está localizada em uma área crítica, pois seria no suposto contato entre o xisto e o xisto milonítico. O resultado da SEV apresenta um erro considerado baixo, isto é abaixo de $8 \%$ o que legitima uma confiabilidade maior nestes dados. Além disso, os dados apresentam um comportamento estável. Entretanto foi necessário mascarar dois dados de IP e, com isso, o comportamento da curva teórica ficou muito bom. É importante ressaltar que analisando isoladamente a curva de resistividade, seria possível identificar mais de 4 camadas, principalmente nas maiores aberturas. Mas foi utilizado o fato da curva de IP apresentar legibilidade maior para "calibrar" a curva de resistividade além da proximidade da SEV 3 com a SEV 1 que foi interpretado com 3 camadas.

Pela tabela gerada a partir da Figura 6.8, identifica-se 4 camadas. A primeira com uma resistividade em torno de 400 S.m e cargabilidade em torno de 3 $\mathrm{mSeg.V/V}$. Assim seria compatível identifica-la como um solo proveniente do xisto. A

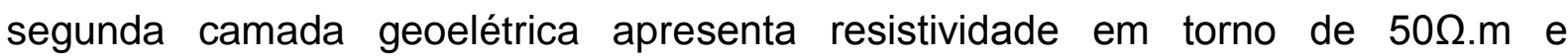
cargabilidade em torno de 1,4 mSeg. $\mathrm{V} / \mathrm{V}$, logo consideravelmente menores que a primeira. Com isso, seria plausível identifica-la como um solo mais saturado. A camada 3 apresenta resistividade parecida com a camada 1, mas cargabilidade maior o que nos faz identifica-lo como o xisto milonítico. E a última camada com resistividade e cargabilidade menor que a terceira seria o xisto. Esse modelo é compatível com o mergulho das camadas para SE, de forma que o gnaisse não é identificado. 


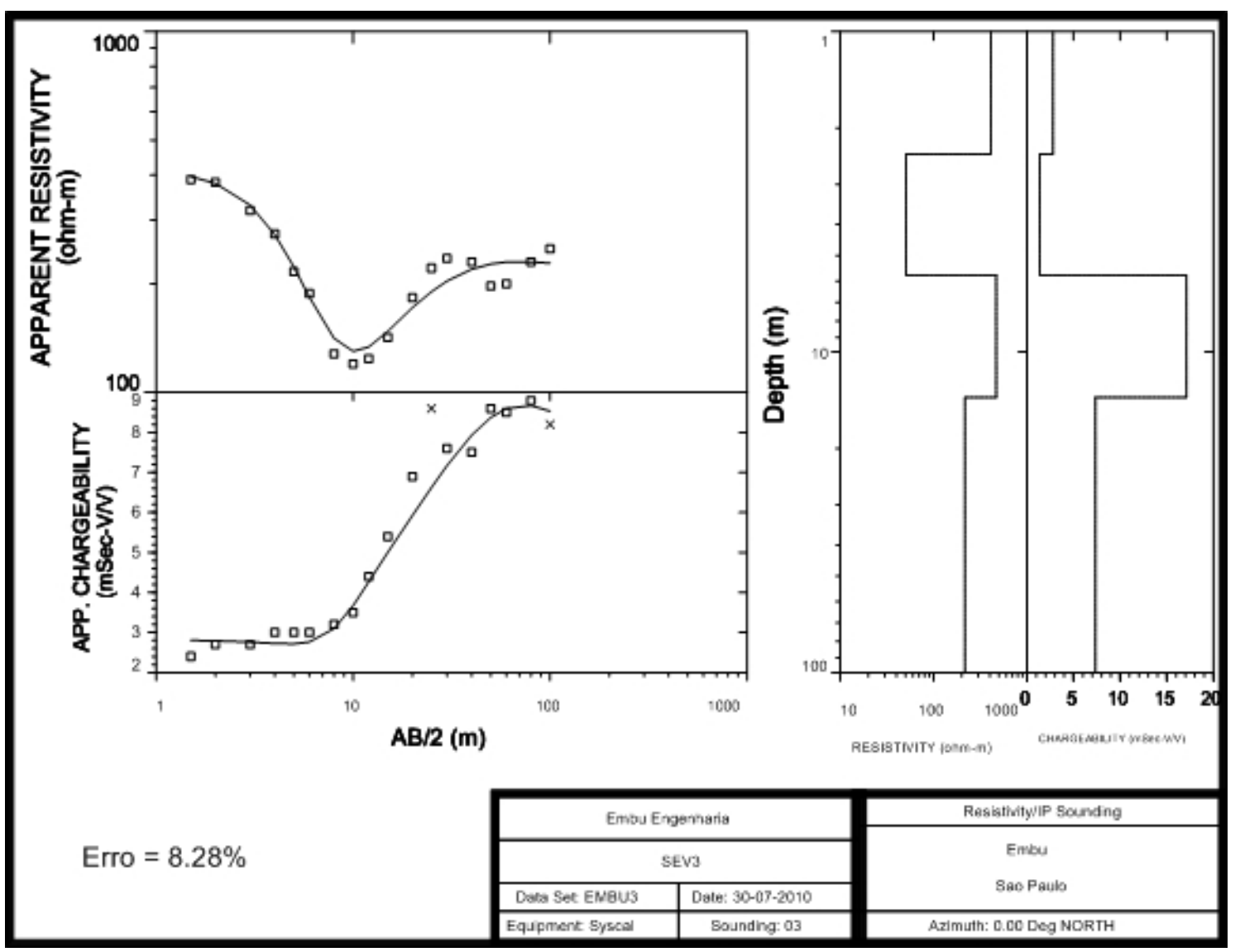

\begin{tabular}{lcccc}
\hline & Camada 1 & Camada 2 & Camada 3 & Camada 4 \\
\hline Resistividade & 411,12 & 50,60 & 470,62 & 216,79 \\
Cargabilidade & 2,81 & 1,37 & 17,10 & 7,3 \\
Profundidade & 2,41 & 5,75 & 13,85 & \\
\hline
\end{tabular}

Figura 6.8: Resultado do processamento da SEV 3

De acordo com o prévio mapa geológico da pedreira (Figura 6.3), a SEV 4 está localizada teoricamente próxima ao contato do xisto com o gnaisse. Os dados não apresentaram problemas e o erro ficou em torno de 6,5\% (Figura 6.9). Foram identificadas 4 camadas, a primeira com uma resistividade alta e cargabilidade baixa, o que nos fez identifica-la como um solo de alteração proveniente do xisto mas com alto teor de alteração. A segunda camada apresenta resistividade alta, mas menor que a camada 1 e com uma cargabilidade mais expressiva. Devido a isso essa camada foi interpretada como um solo de alteração de xisto, mas com um grau de alteração menor, o que justificaria a alta concentração de minerais argilosos que elevaram a cargabilidade. A camada 3 poderia ser interpretada como um xisto alterado ou um xisto fraturado com água em seus poros. Já a camada 4 foi interpretada como um gnaisse fraturado com água, pois apresenta resistividade alta, 
mas substancialmente menor que as resistividades encontradas para o gnaisse nas outras sondagens e cargabilidade quase zero.

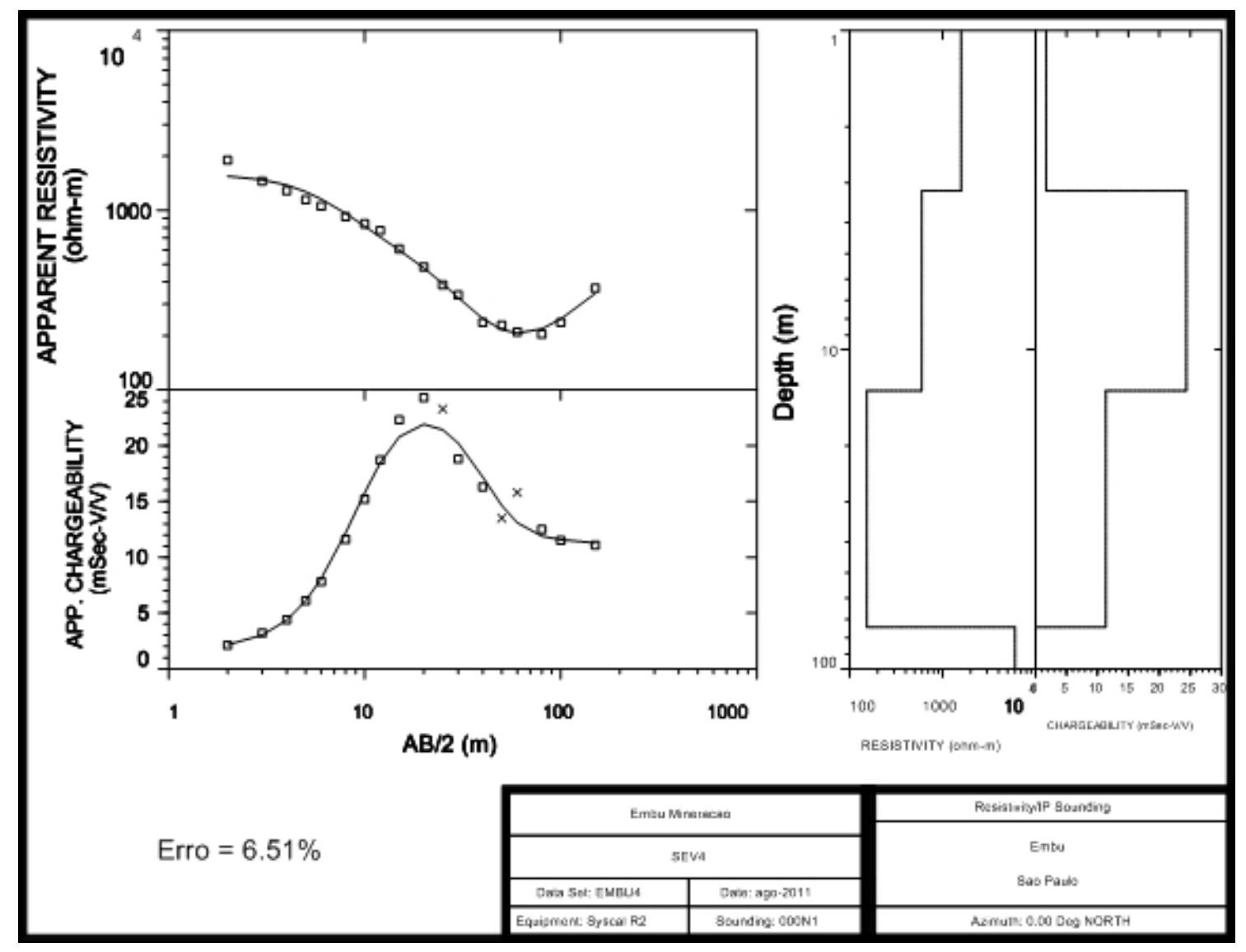

\begin{tabular}{lcccc}
\hline & Camada 1 & Camada 2 & Camada 3 & Camada 4 \\
\hline Resistividade & 1585,07 & 596,73 & 152,77 & 6029,48 \\
Cargabilidade & 1,72 & 24,38 & 11,36 & 0,03 \\
Profundidade & 3,18 & 13,44 & 74,03 & \\
\hline
\end{tabular}

Figura 6.9: Resultado do processamento da SEV 4

A SEV 5 está localizada em uma possível terreno gnáissico. Os dados apresentam um bom comportamento, Figura 6.10, mas assim como em outras sondagens; os dados de resistividade poderiam ter sido ajustados com apenas 3 camadas, mas os contrastes de cargabilidade entre as camadas 1 e 2 são muito pronunciados para serem ignorados. Então foi utilizado o modelo de 4 camadas encontrado nos dados de IP para "calibrar" o modelo de resistividade. 


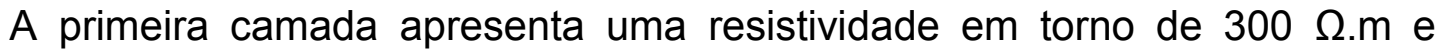
cargabilidade intermediária, o que se justificaria pensar em um solo de alteração de gnaisse. A segunda camada apresenta resistividade semelhante à camada 1, mas uma cargabilidade maior. Assim poderíamos associa-la também a um solo de alteração, mas com um teor menor de intemperismo. A camada 3 tem resistividade relativamente mais alta, sendo interpretada como gnaisse alterado ou fraturado. Já a última camada apresenta valores baixos de resistividade e altos valores de cargabilidade. Logo, podemos interpretá-la como xisto, mergulhando abaixo do gnaisse nessa posição da borda.

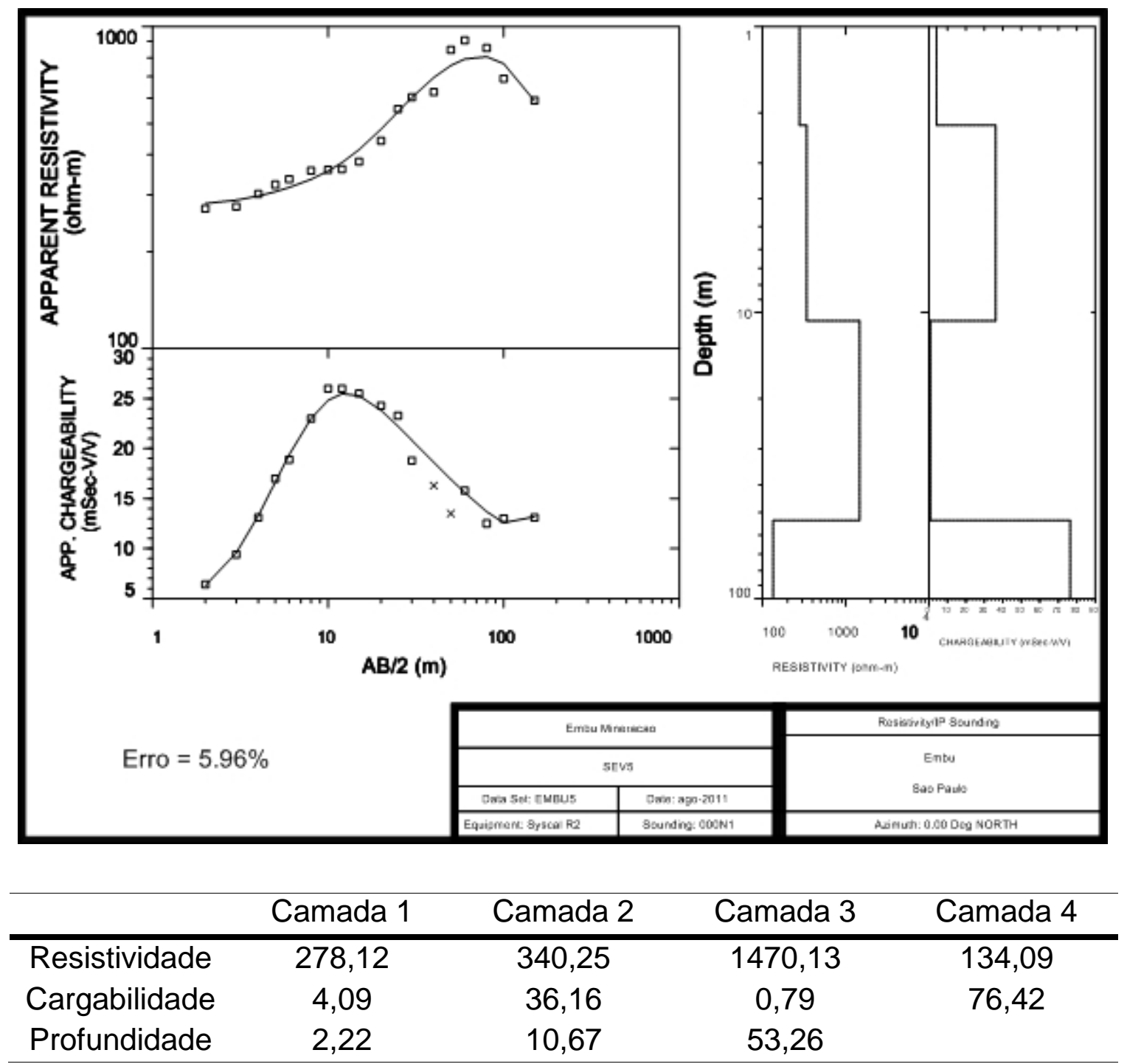

Figura 6.10: Resultado do processamento da SEV 5. 
A SEV 6 está localizada na mesma região de ocorrência de gnaisse das SEVs 5 e 7. Nesta SEV foi possível identificar 4 camadas, Figura 6.11. A primeira pode-se ser identificada como um solo de alteração de gnaisse por apresentar um valor de resistividade intermediário e valores baixos de cargabilidade. A segunda camada, que se encontraria a um profundidade entre $1,5 \mathrm{~m}$ e $6,5 \mathrm{~m}$ aproximadamente, apresentando uma resistividade próxima a camada 1, mas com uma cargabilidade bem maior. Portanto poderia ser identificada como um solo de alteração provindo do gnaisse ou um gnaisse fraturado com intercalações de xisto, o que justificaria o valor de cargabilidade alto. Já a terceira camada apresenta um valor de resistividade alto e um valor de cargabilidade baixo. Assim pode-se relaciona-la a um gnaisse fraturado. Já a última camada apresenta um valor muito expressivo de resistividade porém muito baixo de cargabilidade o que nos indica claramente o gnaisse inalterado.

É importante notar que os ajustes dos dados de IP são pouco satisfatórios, o que explicaria o alto valor do erro encontrado. Entretanto, os valores de resistividade foram muito bem ajustados. Assim como os dados de resistividade apresentam alta qualidade, eles serviram como referencia no processamento desta SEV. Outro fator que é importante resaltar é que esta SEV poderia ser ajustada com 3 camadas e, teria um erro de $6,56 \%$ o que é muito menor que o encontrado. Entretanto optou-se por modelar a SEV com 4 camadas para ser mais condizentes com as SEVs que a circundam. 


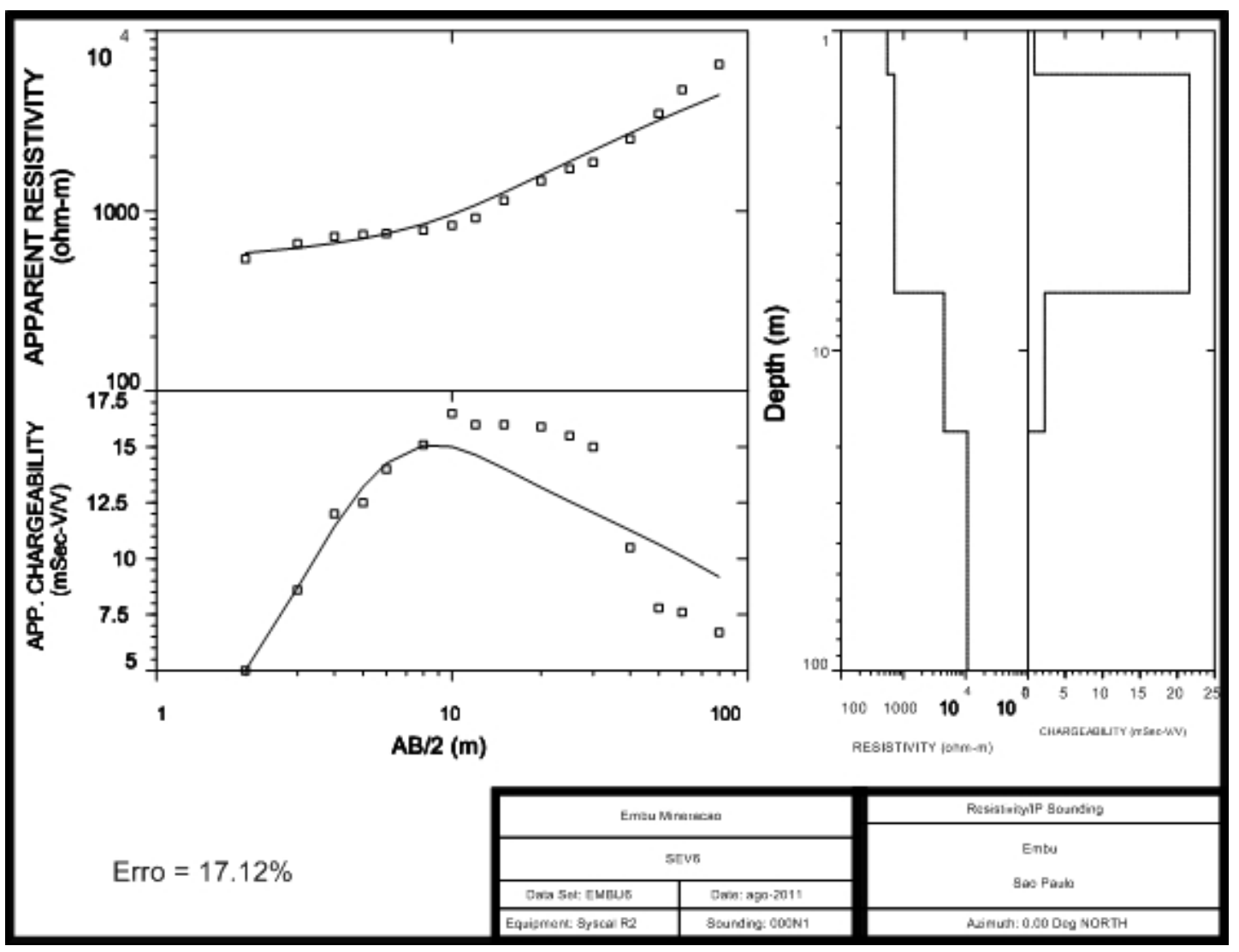

\begin{tabular}{ccccc}
\hline & Camada 1 & Camada 2 & Camada 3 & Camada 4 \\
\hline Resistividade & 550,28 & 719,97 & 4493,55 & 10702,75 \\
Cargabilidade & 9,86 & 21,63 & 2,25 & 0,01 \\
Profundidade & 1,36 & 6,5 & 17,91 & \\
\hline
\end{tabular}

Figura 6.11: Resultado do processamento da SEV 6.

A SEV 7 localiza-se na região de gnaisse e apresenta 3 camadas. É importante resaltar que a curva de cargabilidade não foi muito bem ajustada. Poderíamos ter usado um artifício de inverter cada curva separadamente, mas este artifício não foi utilizado pois consideramos que como a região é a mesma, os dados devem ser processados juntos. Assim não se deu muita relevância aos valores de cargabilidade, que normalmente são mais sujeitos a ruídos. Com isso, como pode ser visto na Figura 6.12, a primeira camada apresenta uma resistividade em torno de 400 Ohm.m com cargabilidade em torno de $30 \mathrm{mSeg} . \mathrm{V} / \mathrm{V}$, sendo razoável identificala como um solo de alteração. A segunda camada apresenta resistividade em torno de 1000 Ohm.m o que poderia ser identificada como um gnaisse mais fraturado ou alterado. Como a curva de resistividade está bem dispersa não iremos considerar o dado de cargabilidade. Já a terceira camada tem valores de resistividade bem 
pronunciados e cargabilidade bem baixa, quase zero. Logo identificamos essa camada como a gnaisse inalterado.

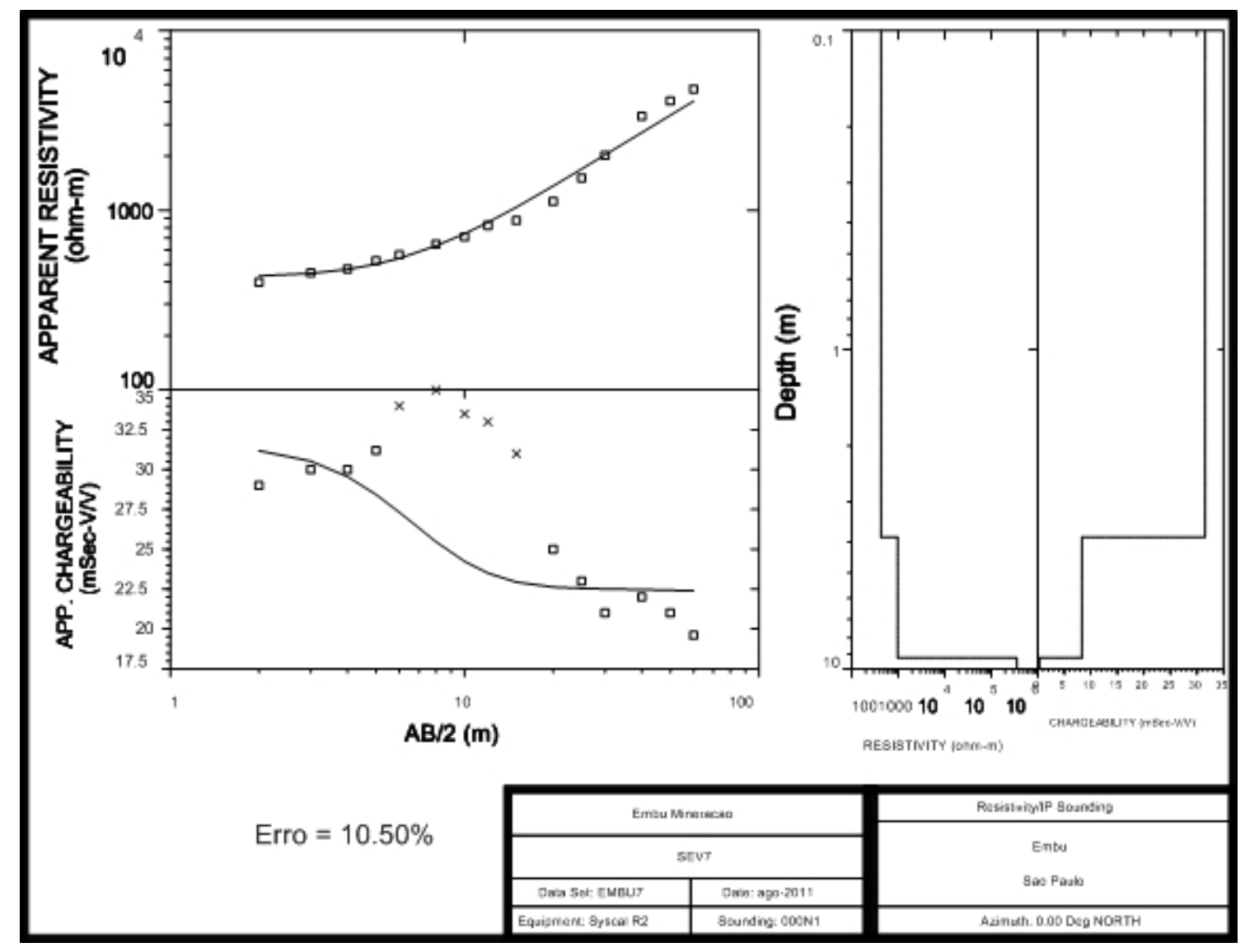

\begin{tabular}{lccc}
\hline & Camada 1 & Camada 2 & Camada 3 \\
\hline Resistividade & 424,56 & 970,95 & 355043,12 \\
Cargabilidade & 31,52 & 8,31 & 0,32 \\
Profundidade & 3,86 & 9,23 & \\
\hline
\end{tabular}

Figura 6.12: Resultado do processamento da SEV 7

Neste primeiro conjunto de dados, nota-se que a maioria das sondagens apresenta de 3 a 4 camadas. O gnaisse inalterado foi identificado nas SEV's 8 e 9 . $O$ topo de gnaisse variou entre aproximadamente $18 \mathrm{~m}$ e $9 \mathrm{~m}$, respectivamente. Logo poderíamos considerar por ora que ele esta cada vez mais raso no sentido oeste no mapa da Figura 6.3.

Por um critério da própria empresa Embu S/A Engenharia e Comércio, as SEV's 8 e 9 não existem. Assim vamos analisar as SEV's 10,11,12,14 e 15. A SEV 13 encontra-se numa região critica então será analisada posteriormente. 
A SEV 10 está localizada na região de borda, com provavelmente ocorrência de xisto. Com um erro abaixo de 10\%, essa sondagem foi considerada de boa qualidade.

Na SEV 10, Figura 6.13, identificou-se 3 camadas. A primeira camada com uma resistividade em torno de 170 Ohm.m e cargabilidade em torno de $3 \mathrm{mV} / \mathrm{V}$ pode ser identificada como um solo de alteração de gnaisse. A segunda camada apresenta valores de resistividade e cargabilidade mais elevados o que nos faz interpreta-la como um solo de alteração provindo do gnaisse ou um gnaisse fraturado com intercalações de xisto, pois a cargabilidade é mais expressiva. A terceira camada começa a uma profundidade em torno de $35 \mathrm{~m}$ e apresenta uma alta resistividade e cargabilidade não muito alta. Porém, ao olharmos para a curva de cargabilidade vê-se que no final ela não esta tão bem ajustada e, foi necessário mascarar dois pontos. Assim a este valor de cargabilidade não deve ser dado tanta confiança. Com isso pode-se interpretar esta camada como o gnaisse. Dessa forma, nessa região o substrato é gnaisse e não xisto como se suspeitava a princípio.

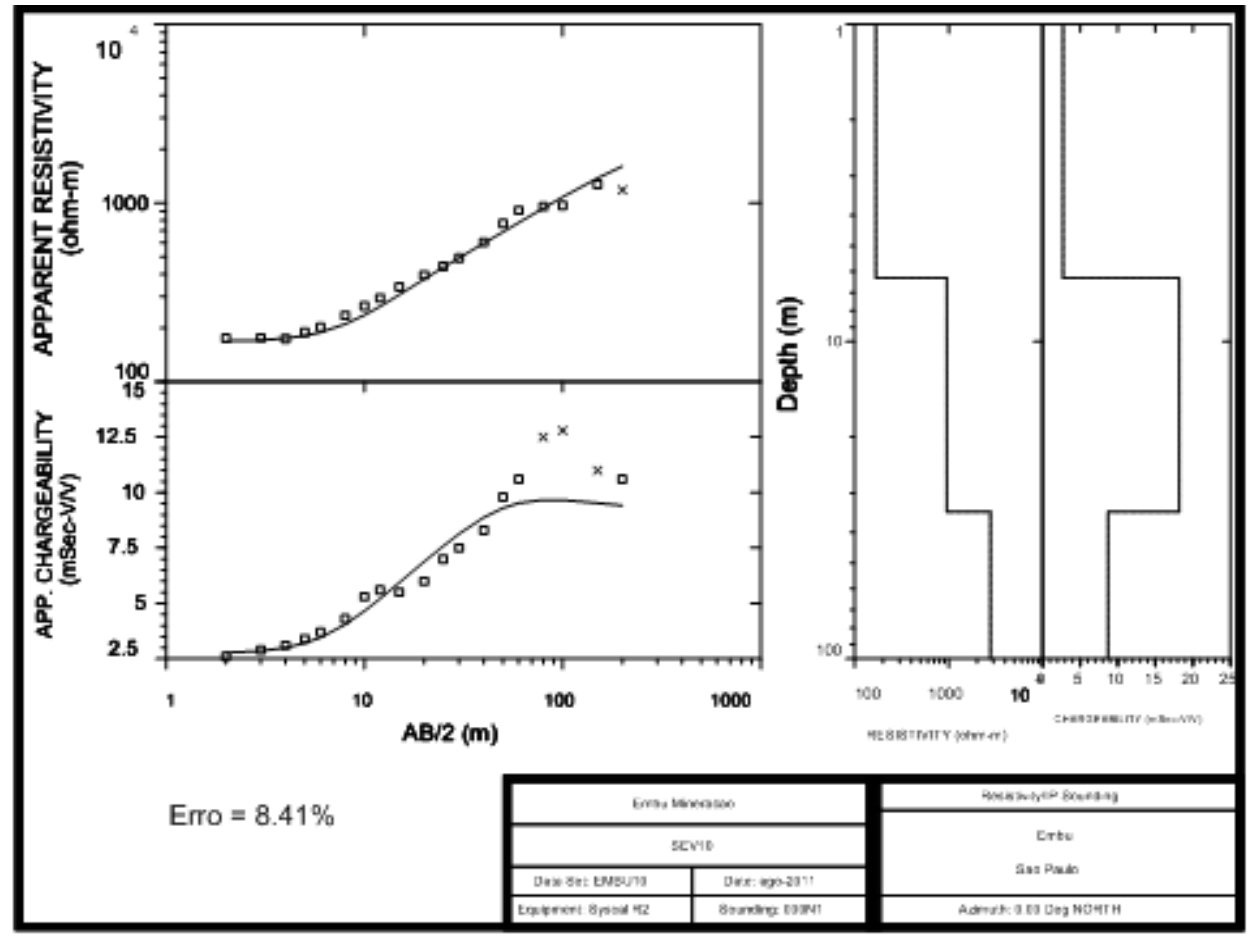

\begin{tabular}{lccc}
\hline & Camada 1 & Camada 2 & Camada 3 \\
\hline Resistividade & 167,58 & 957,76 & 2791,3 \\
Cargabilidade & 2,74 & 18,19 & 8,72 \\
Profundidade & 6,30 & 34,46 & \\
\hline
\end{tabular}

Figura 6.13: Resultado do processamento da SEV 10. 
A SEV 11 esta supostamente na região do gnaisse. Nota-se que as curvas foram bem ajustadas sendo que a de resistividade ficou um pouco melhor que a de cargabilidade, Figura 6.14.

Sendo assim foi possível identificar 4 camadas muito bem pronunciadas em ambas os métodos. A primeira camada apresenta uma resistividade em torno de 500 Ohm.m e cargabilidade em torno de $9 \mathrm{mSeg} . \mathrm{V} / \mathrm{V}$ o que nos faz caracteriza-la como um solo desenvolvido de gnaisse. A segunda camada apresenta um valor de resistividade compatível a gnaisse mas apresenta um alto valor de cargabilidade. Este fato nos faz ponderar que este gnaisse não seria inalterado, mas sim estaria fraturado com intercalações de xisto. A terceira camada apresenta valores de resistividade bem menores e cargabilidade média. Assim poderíamos identifica-la como uma camada de xisto entre os gnaisses das camadas 2 e 4 com aproximadamente $4 \mathrm{~m}$ de espessura.

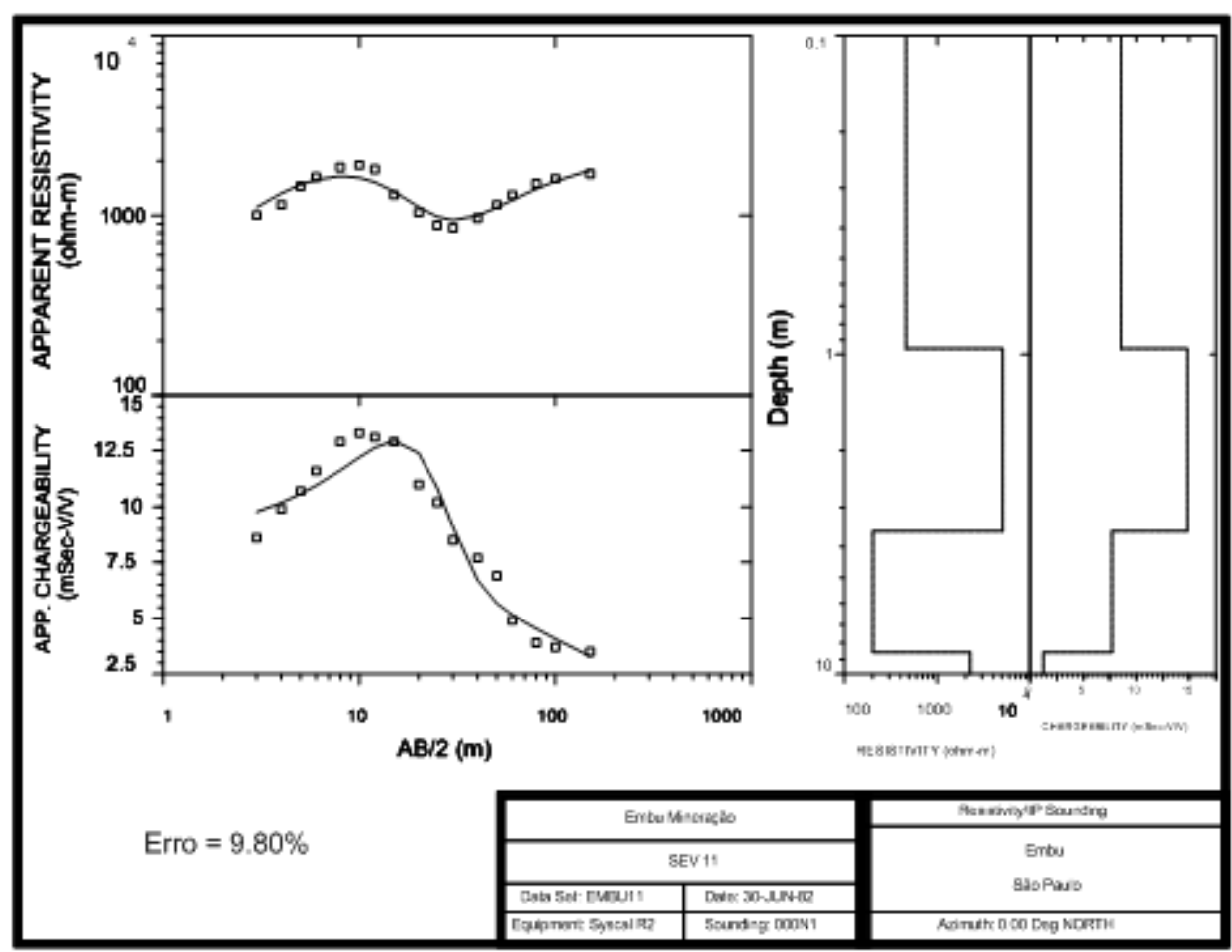

\begin{tabular}{lcccc}
\hline & Camada 1 & Camada 2 & Camada 3 & Camada 4 \\
\hline Resistividade & 465,64 & 5106,55 & 201,26 & 2250,17 \\
Cargabilidade & 8,57 & 14,83 & 7,74 & 1,23 \\
Profundidade & 0,96 & 3,57 & 8,55 &
\end{tabular}

Figura 6.14: Resultado do processamento da SEV 11 
De todas as SEVs, a SEV12, Figura 6.15, foi uma das que apresentou melhor resultado no processamento. Ambas as curvas foram bem ajustadas, o único procedimento realizado foi mascarar um ponto na curva de resistividade que estava fora do padrão. Assim foi possível ajustar as curvas com um modelo de 3 camadas. A primeira camada é bem fina com aproximadamente um metro de espessura e apresenta um valor de resistividade compatível com solo de alteração. A segunda camada apresenta valores de resistividade e cargabilidade alto o que nos leva a correlaciona-la a um gnaisse fraturado. A camada 3 é o gnaisse que começaria a $10 \mathrm{~m}$ de profundidade.

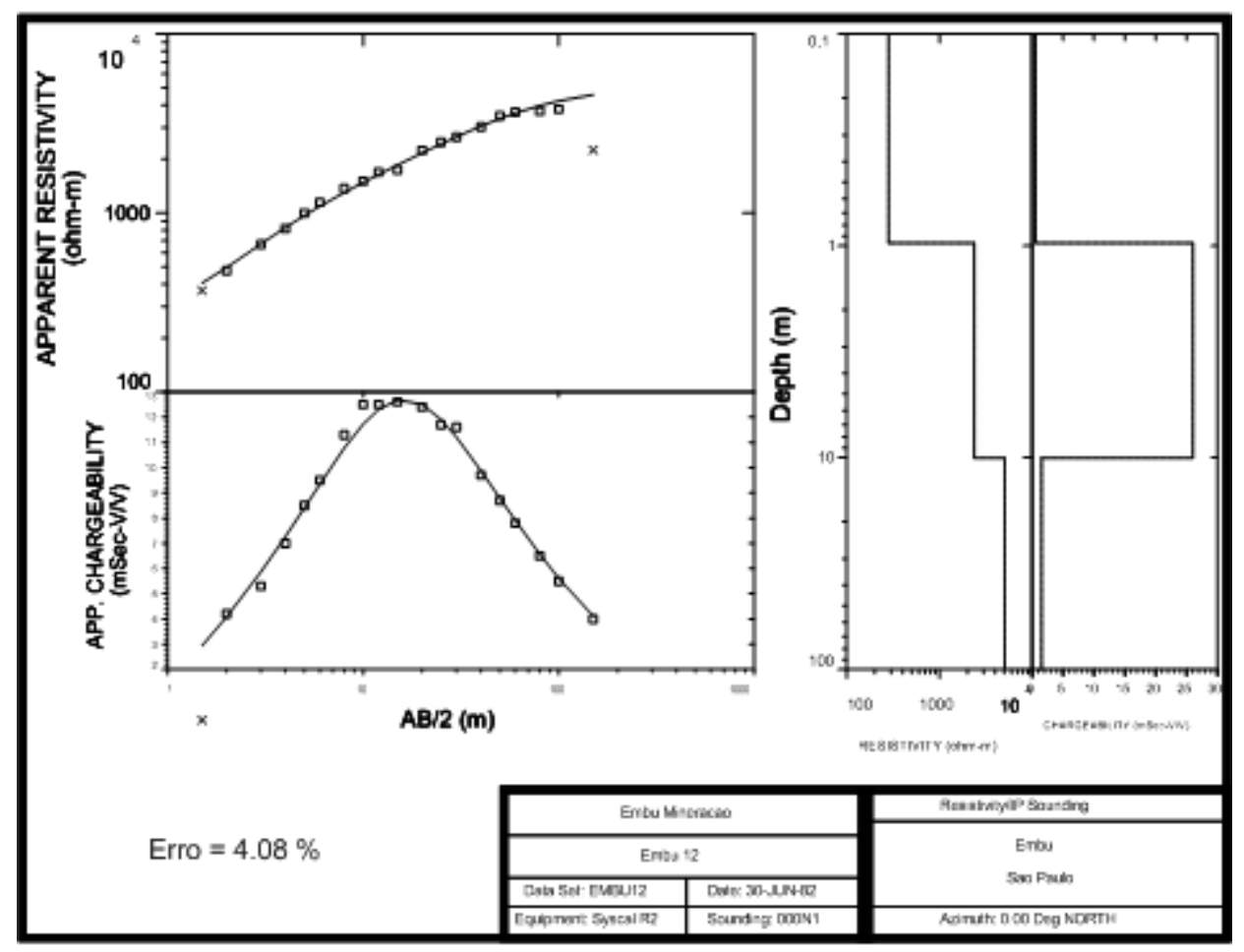

\begin{tabular}{lccc}
\hline & Camada 1 & Camada 2 & Camada 3 \\
\hline Resistividade & 281,71 & 2366,78 & 5082,49 \\
Cargabilidade & 0,58 & 26,04 & 1,53 \\
Profundidade & 0,97 & 10,01 & \\
\hline
\end{tabular}

Figura 6.15: Resultado do processamento da SEV 12 
A SEV13 foi executada em região próxima do contato com o xisto para verificar a espessura de capeamento e também auxiliar na interpretação do modelo geológico, cujo pressuposto é de que o xisto deveria estar sotoposto ao gnaisse nesse local, com mergulho para SE.

Analisando o resultado da SEV 13 nota-se que o inicio de ambas as curvas foram bem modeladas, mas o final nem tanto. Este fato é realçado na curva de cargabilidade, o que pode ser visualizado no modelo de camadas que é apresentado a direita da Figura 6.14 e na tabela onde a o valor de cargabilidade para as camadas 3 e 4 são praticamente imperceptíveis. Talvez com um modelo melhor, a diferença fosse mais pronunciada. Todos estes fatores contribuíram para termos um erro um pouco acima do ideal de $10 \%$.

Assim foi possível o uso de 4 camadas para modelar esta sondagem. A primeira com uma espessura em torno de $2 \mathrm{~m}$ apresentando resistividade em torno de 150 Ohm.m e cargabilidade baixa em torno de $1,5 \mathrm{mSeg} . \mathrm{V} / \mathrm{V}$ o que nos faz interpreta-la como um solo de alteração. A camada dois já apresenta uma resistividade em torno de 3000 Ohm.m e cargabilidade bem maior também, interpretada como gnaisse fraturado. A camada 3 apresenta um valor altíssimo de resistividade e cargabilidade também alta. Mas como já exposto acima este valor pode não ser muito confiável. Assim interpreta-se a camada 3 como um gnaisse inalterado talvez com alguma porção com intercalação de xisto, com aproximadamente $15 \mathrm{~m}$ de espessura. A última camada já apresenta um valor de resistividade bem mais baixo, em torno de 80 Ohm.m, o que nos faz interpreta-la como o xisto que começa em torno de $30 \mathrm{~m}$ de profundidade. Estes valores corroboram o mergulho das camadas para SE, com o xisto mergulhando abaixo do gnaisse. 


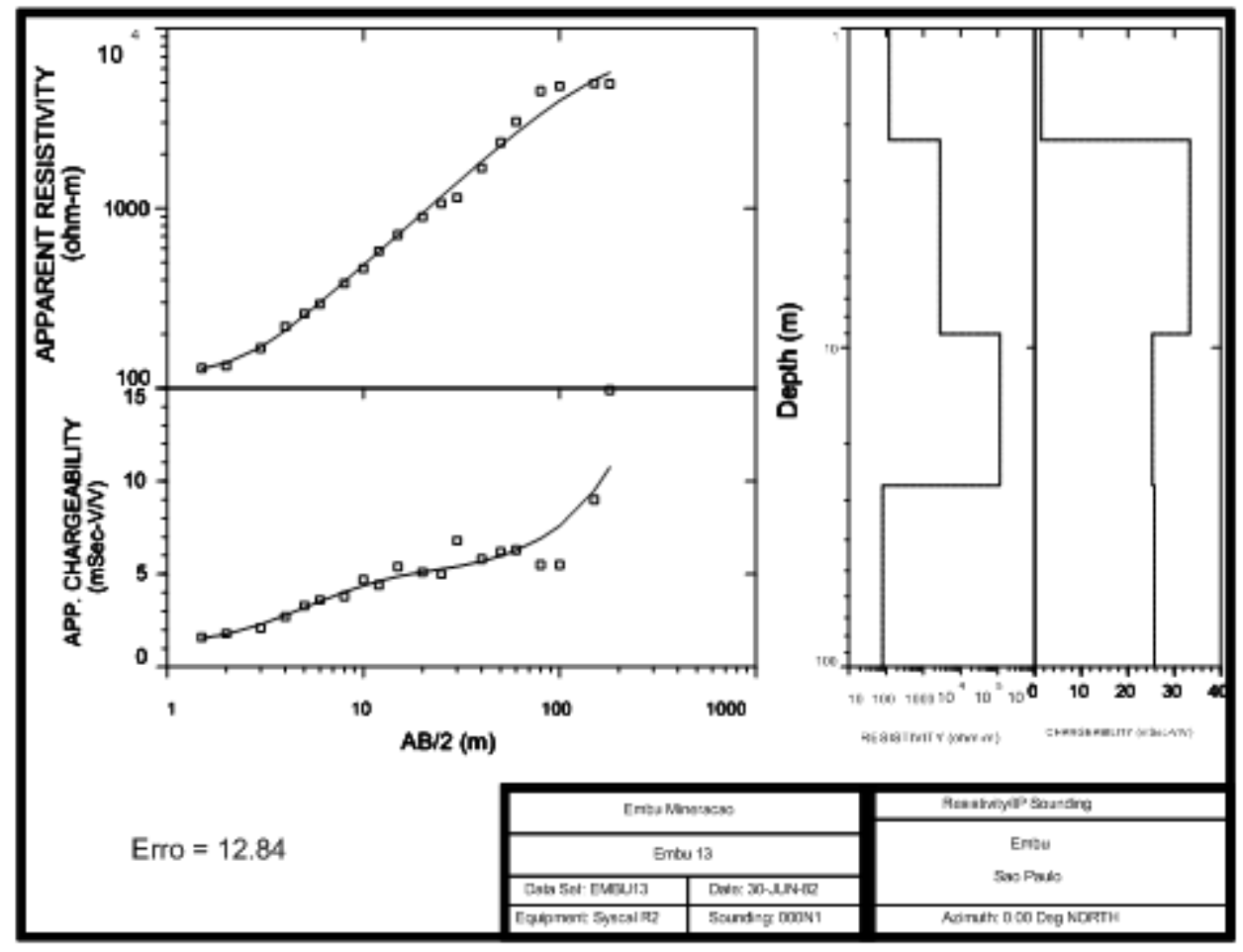

\begin{tabular}{lcccc}
\hline & Camada 1 & Camada 2 & Camada 3 & Camada 4 \\
\hline Resistividade & 120,14 & 2789,22 & 115669,19 & 80,91 \\
Cargabilidade & 1,35 & 33,33 & 25,33 & 25,71 \\
Profundidade & 2,23 & 9,04 & 26,99 & \\
\hline
\end{tabular}

Figura 6.16: Resultado do processamento da SEV 13 
$\mathrm{Na}$ SEV 14, apresentado na Figura 6.17, o erro encontrado foi baixo, entretanto nota-se que os dados estão bem dispersos. Ainda sim foi possível o uso de 3 camadas. A primeira camada apresenta resistividade em torno de $1000 \mathrm{Ohm} . \mathrm{m}$ e resistividade em torno de $14 \mathrm{mSeg.V} / \mathrm{V}$. Assim podemos interpreta-la como um solo de alteração de gnaisse. A segunda camada apresenta valores de resistividade e cargabilidade altos o que poderia ser correlacionado com o mesmo solo de alteração da camada 1. Já a camada 3 apresenta valores de resistividade próximos a 4000 Ohm.m onde poderíamos relaciona-la a um gnaisse inalterado.

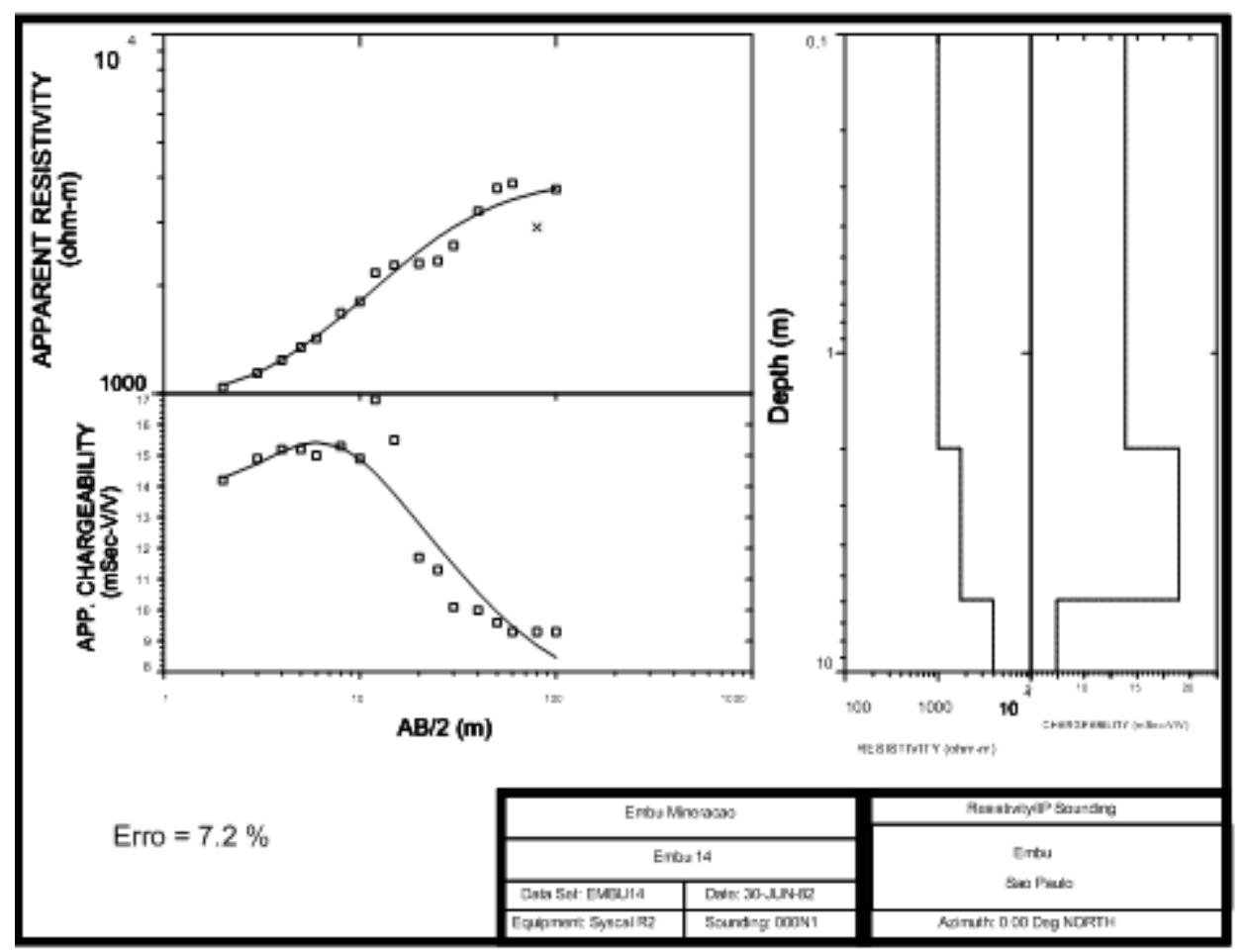

\begin{tabular}{lccc}
\hline & Camada 1 & Camada 2 & Camada 3 \\
\hline Resistividade & 998,66 & 1748,47 & 3931,62 \\
Cargabilidade & 13,88 & 18,92 & 7,42 \\
Profundidade & 1,98 & 5,94 & \\
\hline
\end{tabular}

Figura 6.17: Resultado do processamento da SEV 14. 
Na SEV 15, Figura 6.18, foi possível interpretar 3 camadas com um padrão interessante pois os valores de resistividade aumentam bem como os de cargabilidade diminuem com a profundidade. Este fato mostra que quanto mais profundo investigamos mais rocha com teor gnaissico encontramos. Assim identificamos a primeira camada como solo de alteração por apresentar valores de resistividade e cargabilidade intermediários. A segunda camada como um gnaisse talvez fraturado com preenchimento de minerais argilosos. E, por fim a última camada como o gnaisse inalterado.

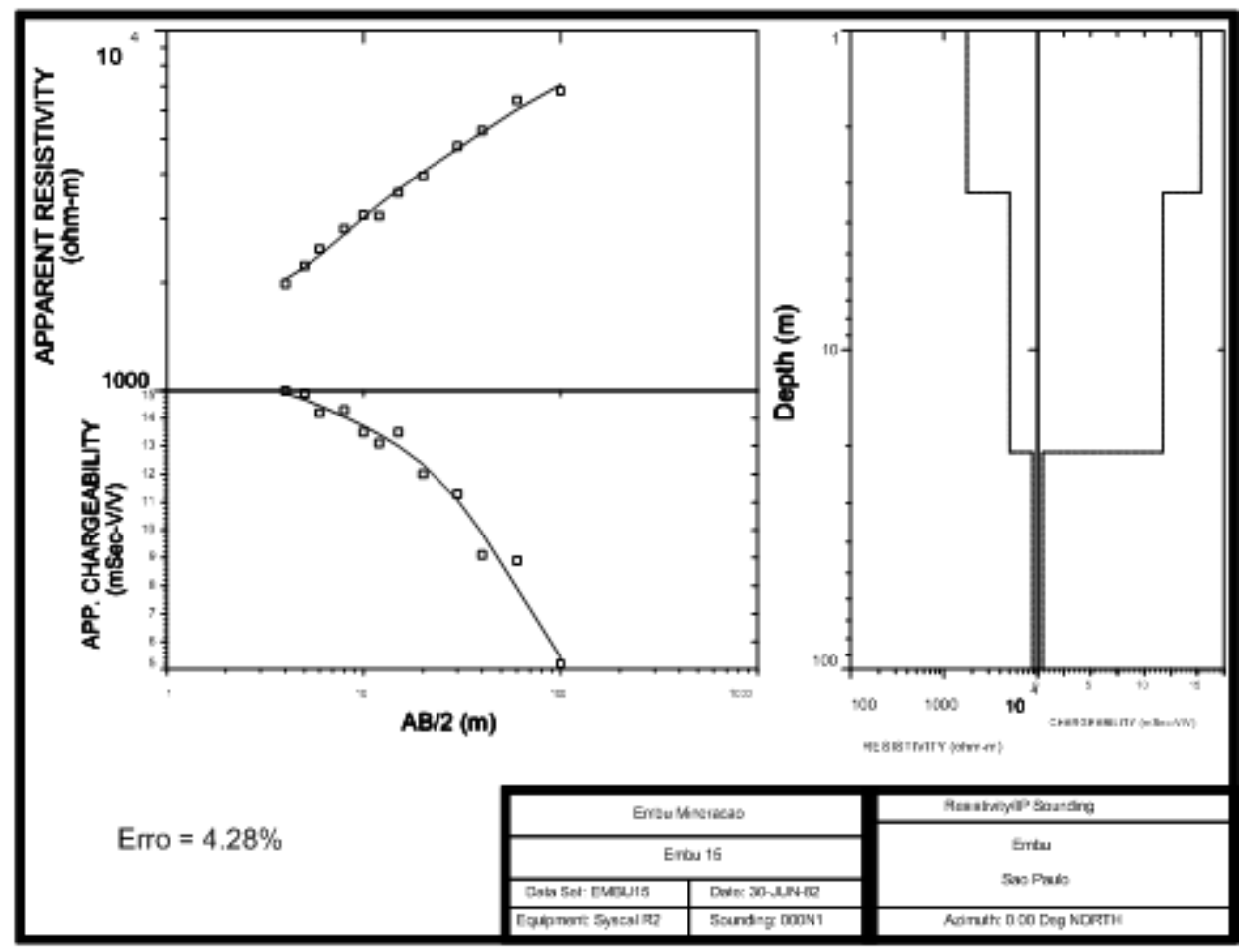

\begin{tabular}{lccc}
\hline & Camada 1 & Camada 2 & Camada 3 \\
\hline Resistividade & 1768,03 & 5005,09 & 8807,65 \\
Cargabilidade & 15,35 & 11,74 & 0,46 \\
Profundidade & 3,22 & 20,92 & \\
\hline
\end{tabular}

Figura 6.18: Resultado do processamento da SEV 15. 


\subsection{Caminhamento Elétrico}

\subsubsection{Interpretação dos dados}

Os dados de Caminhamento Elétrico foram interpretados no programa RES2DInv. Este é um programa desenvolvido por Geotomo Software Malaya (Geotomo, 2011). A partir de sub-rotinas utilizando o método das diferenças finitas, o programa automaticamente determina um modelo de resistividade de 2D para a subsuperfície. Para isso necessita apenas de dados obtidos em levantamentos elétricos. O programa foi projetado para inverter grandes conjuntos de dados, cerca de 200 a 10000 dados coletados em um sistema contendo vários eletrodos, de 25 a 16000 eletrodos. Estes eletrodos geralmente estão alinhados com espaçamento constante. Entretanto, o programa também inverte os dados quando o alinhamento não é uniforme. Os arranjos lineares que o programa aceita são Wenner, WennerSchlumberger, polo-polo, polo-dipolo, dipolo-dipolo, gradiente e dipolo equatorial.

O modelo 2D utilizado na inversão consiste em um grande número de blocos retangulares. A Figura 6.21a (Geotomo, 2011) mostra um arranjo de blocos que está frouxamente ligado a distribuição dos dados na pseudossecção. A distribuição e o tamanho dos blocos são automaticamente gerados pelo programa, usando a distribuição de dados coletados como um guia. A profundidade dos blocos é aproximadamente a profundidade média de investigação a partir dos eletrodos mais afastados (Edwards, 1977 apud Geotomo, 2011). A Figura 6.21b mostra outra maneira de distribuir os blocos. 


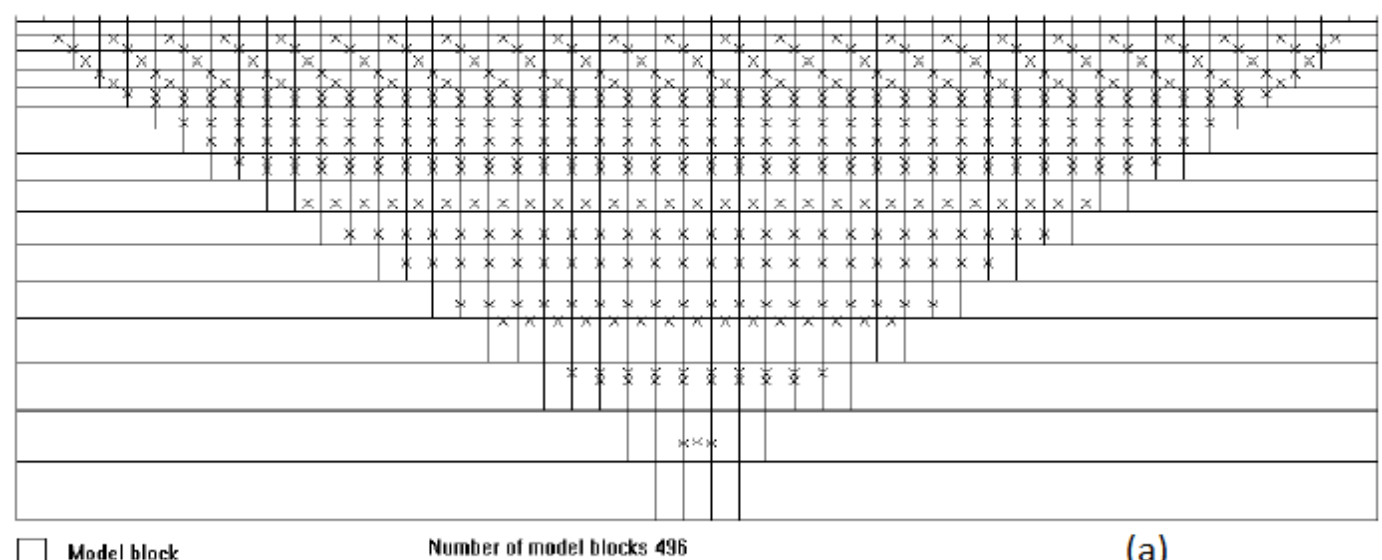

(a)

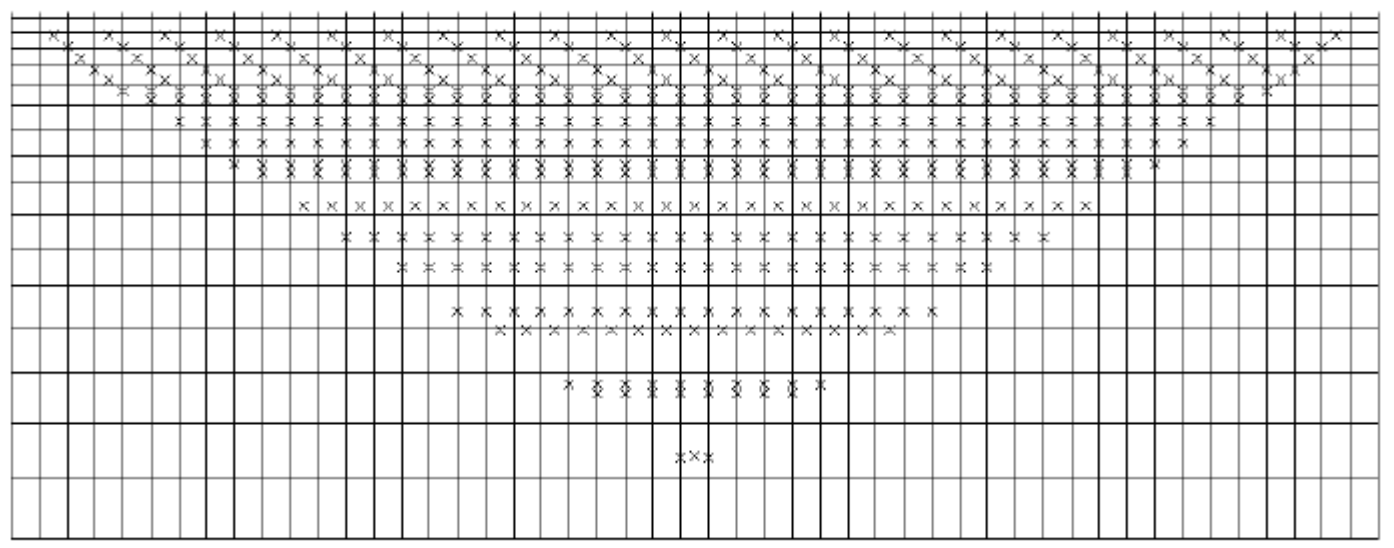

Model block

Number of model blocks 784

(b)

Datum point

Number of datum points 469

Figura 6.21: Dois possíveis arranjos dos blocos usado para o modelo 2D. Retirado de Geotomo 2011.

Os dados foram coletados conforme a Figura 6.3. Para facilitar a identificação do começo e do final de cada caminhamento, o sentido de caminhamento é marcado com uma seta que indica o ponto final do perfil.

\subsubsection{Resultados e discussões}

Os dados foram arranjados de modo que os caminhamentos 1,3 e 4 ficassem juntos pois eles estão próximos no mapa. Assim os resultados da inversão estão nas Figuras 6.22 a 6.24. E, o caminhamento 2 está na Figura 6.25.

As seções referentes ao caminhamento 01 apresentaram um erro RMS baixo, 5 para os valores de resistividade e 16,4 para o de cargabilidade. Para todos os modelos de inversão de cargabilidade apresentados neste trabalho, as cores mais frias representam concentração menor de minerais argilosos com isto menores 
valores de cargabilidade. As cores mais quentes, uma maior concentração logo valores maiores de cargabilidade.

Essa linha, assim como as demais linhas de CE, foi realizada de forma a procurar identificar o contato gnaisse - xisto. Dessa forma, notamos que este caminhamento passa por todos os três tipos rochosos existentes na pedreira. Em 6.22(a) observamos no início uma estrutura bem resistiva e em $180 \mathrm{~m}$ um contorno bem marcado entre o corpo resistivo, em torno de 10000 Ohm.m e um corpo condutivo em torno de 500 Ohm.m. Logo podemos considerar que nesta localização esta o contato entre um gnaisse possivelmente são e o xisto. Este contato está posicionado em $180 \mathrm{~m}$. Na parte final do caminhamento, em torno de $280 \mathrm{~m}$ nota-se que é marcado uma anomalia resistiva, porém com valores um pouco menores de resistividade. Esta anomalia pode ser relacionada com o xisto minolítico.

Assim, analisando a seção de cargabilidade da Figura 6.22(b) notamos que como na seção de resistividade, em $180 \mathrm{~m}$ encontramos um contato entre baixos valores de cargabilidade, em torno de $10 \mathrm{mV} / \mathrm{V}$, e valores altos, em torno de 30 $\mathrm{mV} / \mathrm{V}$. Com isso podemos demarcar um contato entre gnaisse que apresenta valores baixos de cargabilidade e xisto, que apresenta valores altos. Este contato se estende até $220 \mathrm{~m}$. Em torno de $240 \mathrm{~m}$ encontramos em menores profundidades uma região com cargabilidade próxima a zero, e em paralelo valores acima de 3000 Ohm.m o que nos faz identificá-la como um gnaisse possivelmente inalterado. Abaixo deste gnaisse, encontramos uma estrutura com altos valores de cargabilidade na Figura 6.22(b) e menores valores de resistividade na Figura 6.22(a). A partir de $280 \mathrm{~m}$, como acontece na seção de resistividade, também encontramos um padrão de cargabilidade diferente onde há locais indicando valores altos e outros indicando valores baixos. Como o xisto minolítico apresenta composições intermediárias entre o xisto e o gnaisse podemos demarcar este local como o xisto minolítizado. 
(a)

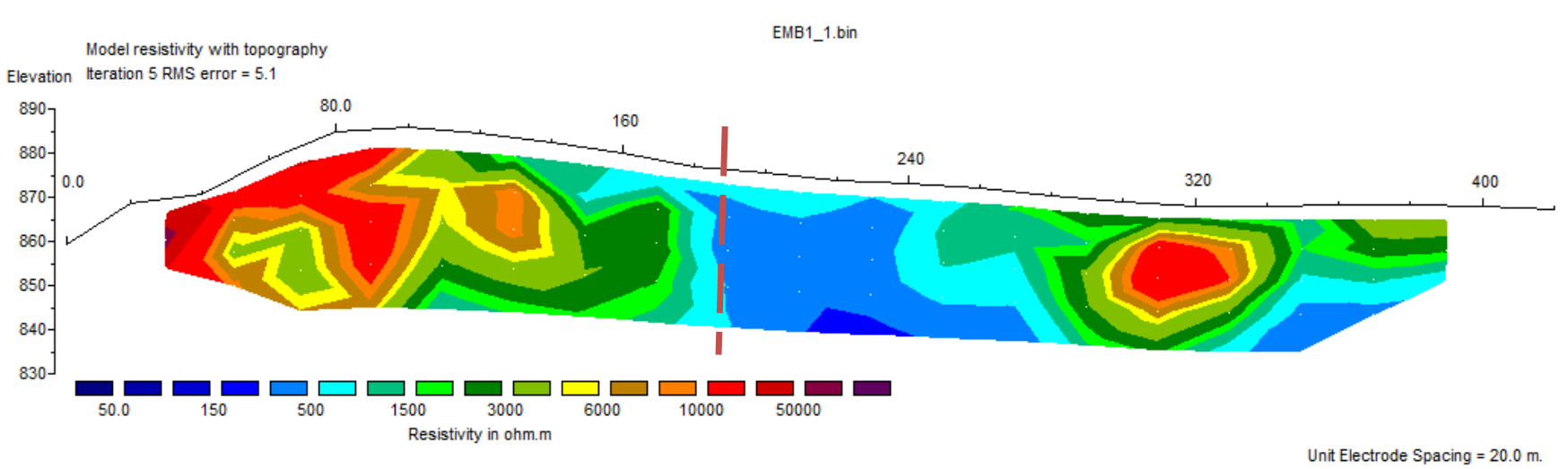

Horizontal scale is 47.27 pixels per unit spacing

Vertical exaggeration in model section display $=1.23$

First electrode is located at $0.0 \mathrm{~m}$.

Last electrode is located at $420.0 \mathrm{~m}$

(b)

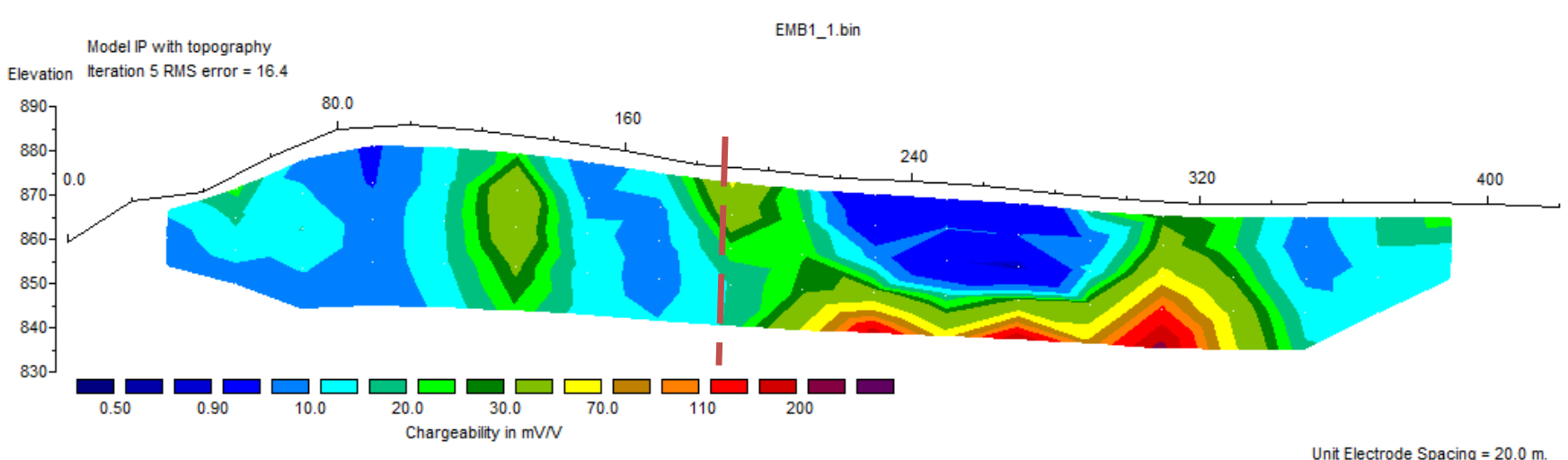

Horizontal scale is 47.27 pixels per unit spacing

Vertical exaggeration in model section display $=1.23$

First electrode is located at $0.0 \mathrm{~m}$.

Last electrode is located at $420.0 \mathrm{~m}$

Figura 6.22: Resultado da inversão de resistividade (a) e cargabilidade (b) para o CE01.

Para corroborar as interpretações do CE01, na Figura 6.22(c) encontra-se uma cópia do mapa de resistividade aliado a fotos tiradas durante a aquisição dos dados na pedreira. Nesta figura podemos ver que tanto a interpretação do gnaisse quanto do xisto condizem com a geologia local. 


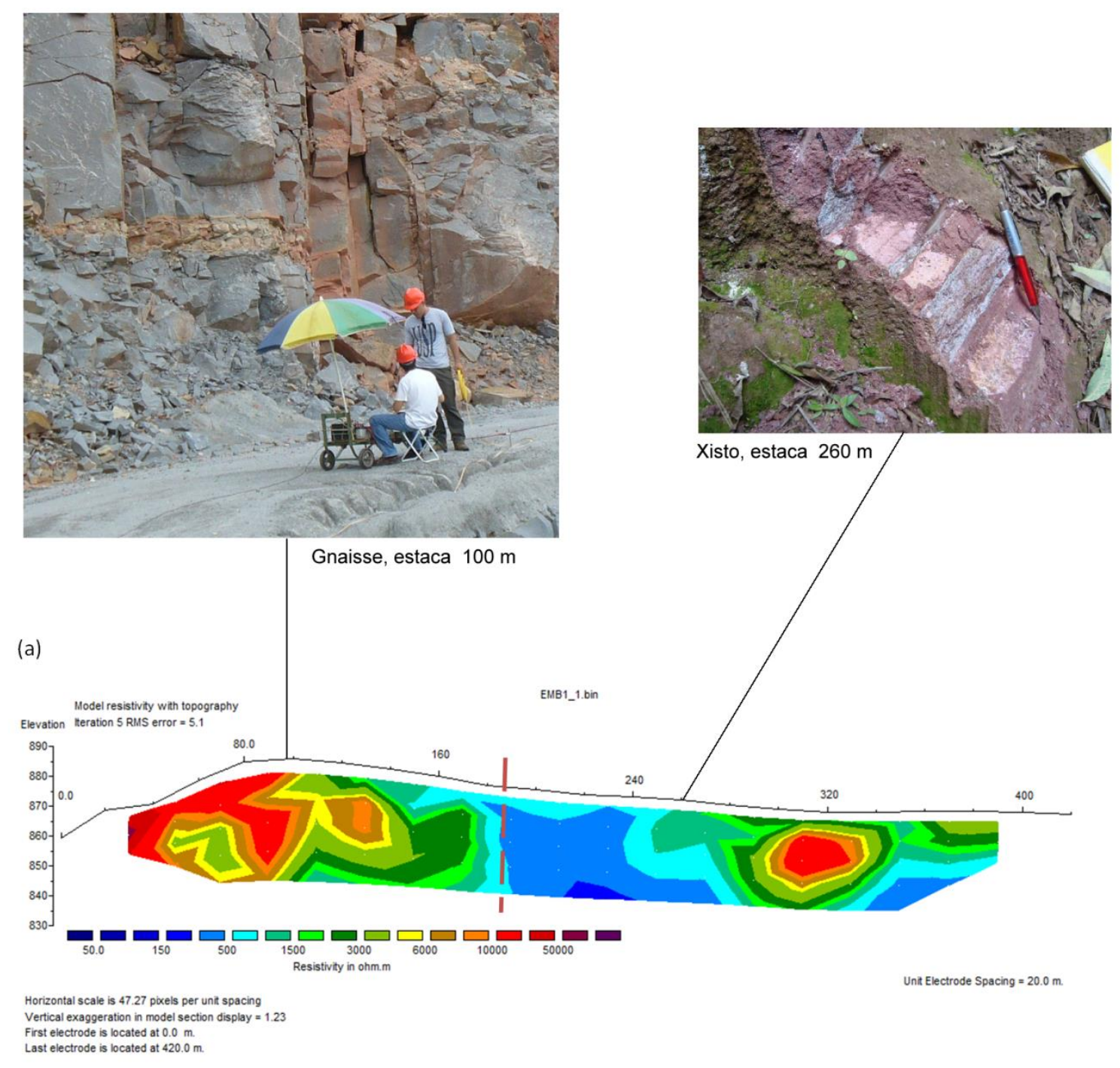

Figura 6.22(c): Resultado da inversão de resistividade (a) para o CE01 com fotos tiradas durante a aquisição dos dados, em 2011.

A seção de resistividade da Linha 03 (Figura 6.23a) apresenta um erro RMS aceitável, em torno de 17. Nesta seção é possível identificar que a partir de 100m há um contato em diagonal entre uma estrutura com resistividade em torno de 10000 Ohm.m e uma estrutura com resistividade em torno de 500 Ohm.m. Este contato podem ser classificado como o contato entre o gnaisse inalterado e o xisto.

Na seção de cargabilidade (Figura 6.23b), observa-se o oposto, isto é, o gnaisse apresenta valores altos de cargabilidade, acima de $50 \mathrm{mV} / \mathrm{V}$, e o xisto valores baixos, em torno de $1 \mathrm{mV} / \mathrm{V}$. Como o erro desta seção é de 
aproximadamente $62 \%$ podemos dar maior credibilidade a seção de resistividade, Figura 6.23(a).

Na Figura 6.3 observa-se que o CE03 passa na sua porção final pela SEV04. A SEV04 identifica o xisto sobre o gnaisse em concordância com a interpretação prévia de Alves (2102) para a litologia local.

(a)

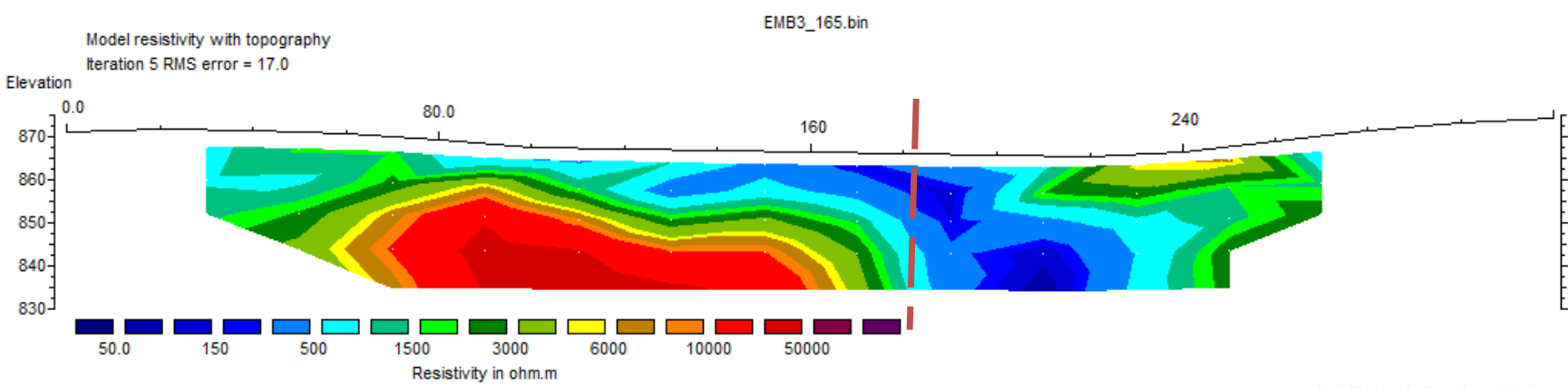

Horizontal scale is 60.55 pixels per unit spacing

Vertical exaggeration in model section display $=0.92$

First electrode is located at $0.0 \mathrm{~m}$.

Last electrode is located at $320.0 \mathrm{~m}$.

(b)

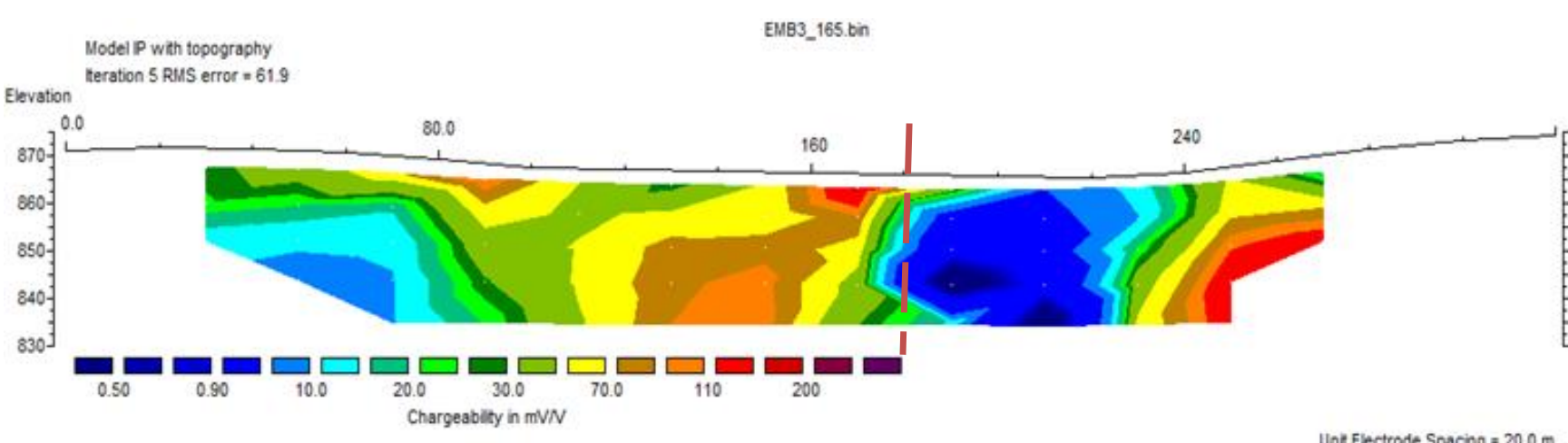

Horizontal scale is 60.55 pockels per unt spacing

Vertical exaggeration in model section display $=0.92$

First electrode is located at $0.0 \mathrm{~m}$.

Last electrode is located at $320.0 \mathrm{~m}$

Figura 6.23: Resultado da inversão de resistividade (a) e cargabilidade (b) para o CE03.

$\mathrm{Na}$ Figura 6.23(c), foi demarcado a área de encontro entre o CE03 e a SEV04 e esta SEV foi novamente reproduzida para mostrar que a interpretação entre ambos os métodos se corroboram além de se complementarem. 

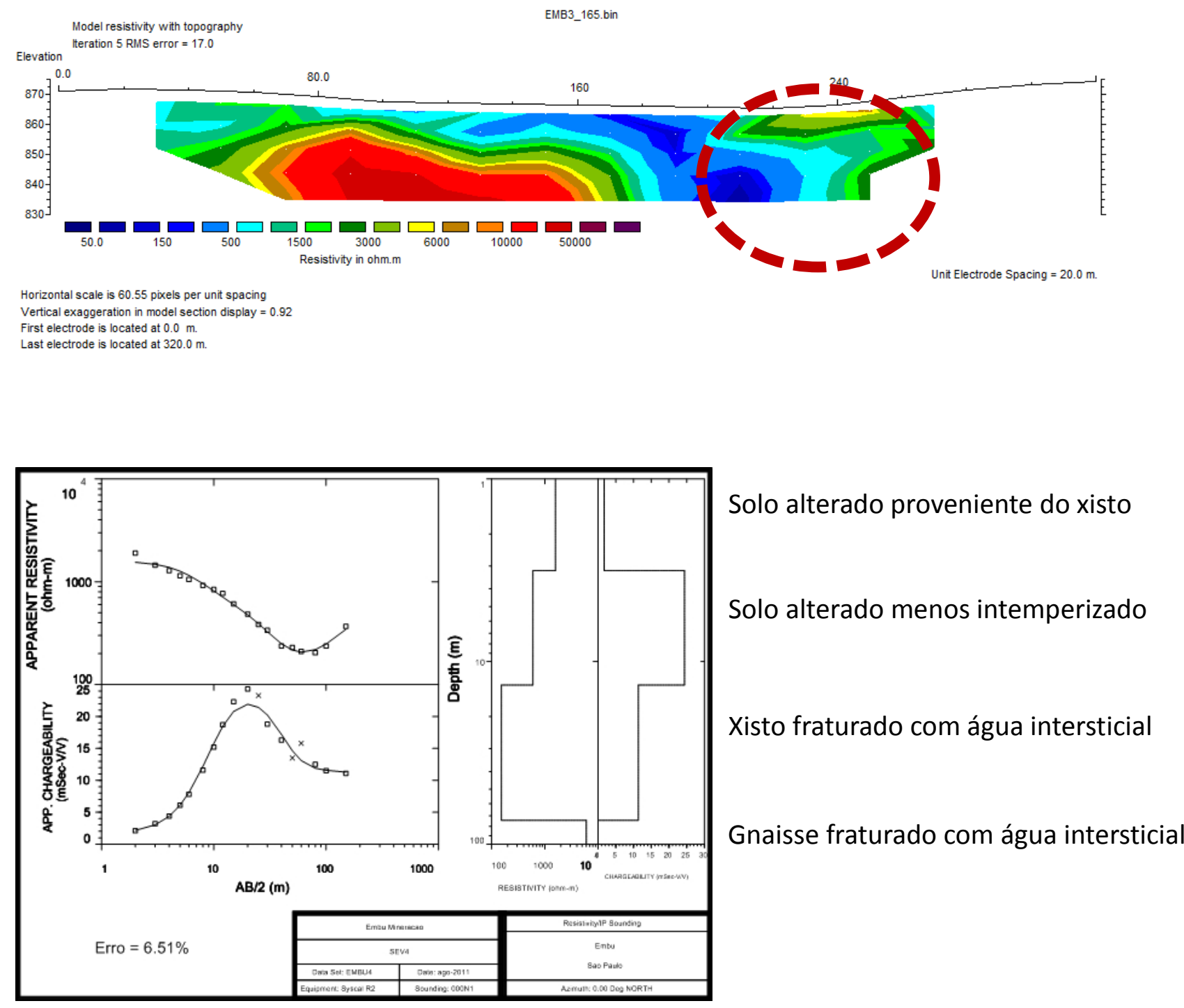

\begin{tabular}{lcccc}
\hline & Camada 1 & Camada 2 & Camada 3 & Camada 4 \\
\hline Resistividade & 1585,07 & 596,73 & 152,77 & 6029,48 \\
Cargabilidade & 1,72 & 24,38 & 11,36 & 0,03 \\
Profundidade & 3,18 & 13,44 & 74,03 & \\
\hline
\end{tabular}

Figura 6.23(c): O círculo vermelho na seção de caminhamento representa a área de encontro entre o CE03 e a SEV04 e abaixo, foi reproduzido a SEV04 com a interpretação. 
No caminhamento 04 notamos que o erro é baixo para ambas as seções (Figura 6.24). Na seção de resistividade notamos que em $85 \mathrm{~m}$ há uma quebra entre uma mesma estrutura resistiva o que indica uma fratura nesta localização. A partir de $90 \mathrm{~m}$ identificamos uma estrutura com resistividade em torno de 50000 Ohm.m o que pode ser correlacionada com o gnaisse. A partir de $240 \mathrm{~m}$ identifica-se uma estrutura mais condutora, iniciando com valores acima de $500 \mathrm{Ohm} . \mathrm{m}$ até valores em torno de 150 Ohm.m o que indicaria o contato do gnaisse com o xisto minolítico indo em direção ao xisto mais inalterado. Na seção de cargabilidade notamos uma correlação das estruturas com as conclusões feitas na seção de resistividade.

Este caminhamento passa pelas SEVs 7 e 6 , nesta ordem. Onde a SEV 7 corresponde ao inicio do caminhamento, a SEV 6 ao meio (Figura 6.24(c)). Um pouco aquém do final do caminhamento encontra-se a SEV 5, portanto tentaremos correlacionar as conclusões também com esta SEV. Na SEV 7 foi identificado um gnaisse fraturado sobre o gnaisse são. E na Figura 6.24(a) é possível visualizar uma área condutiva com teor intermediário de cargabilidade sobre uma área resistiva sem muita variação nos valores de cargabilidade. Talvez não encontramos um valor pronunciado marcando o gnaisse devido a própria rocha, pois na SEV 7 também não foi possível ajustar a curva de cargabilidade. Na SEV 6 foi identificada uma camada de solo seguido por pacotes de gnaisse fraturado até chegar ao gnaisse inalterado. Logo há uma fina camada de rocha condutiva e um pacote de rochas resistivas. Este padrão é encontrado em toda a parte central da seção. Até agora estes resultados estão compatíveis com a litologia esperada para essa região. A SEV 5 por sua vez identifica duas camadas de solo, o gnaisse fraturado e o xisto a uma profundidade de $53 \mathrm{~m}$. No final do caminhamento 04 , embora seja possível visualizar o contato claramente, esse parece mergulhar em direção contrária. Devido a isso, recomendase que se faça uma investigação direta nesta região para assim rever o comportamento da litologia neste local. 
(a)

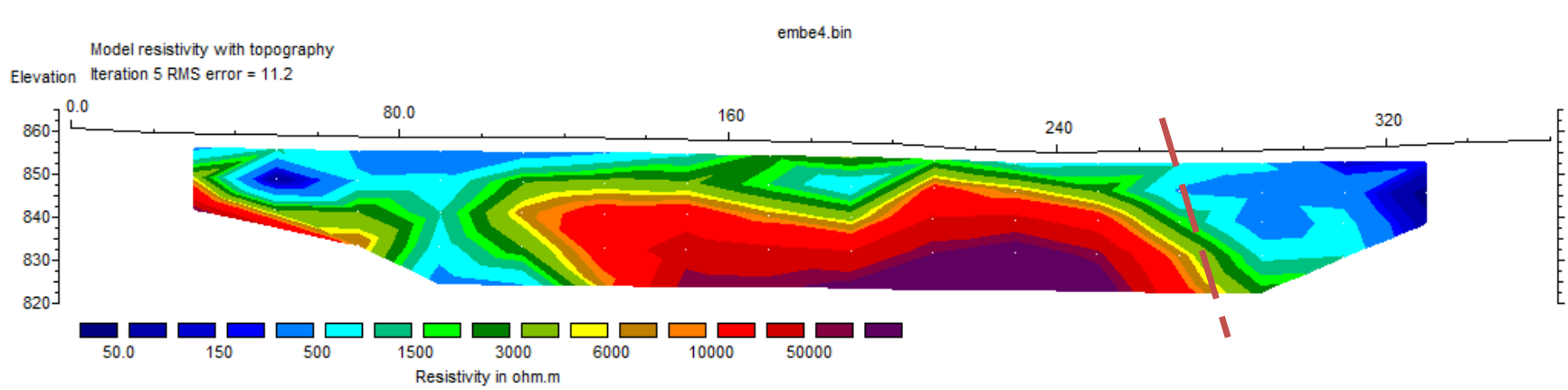

Horizontal scale is 53.63 pixels per unit spacing

Unit Electrode Spacing $=20.0 \mathrm{~m}$.

Virst exaggeration in model section display $=1.04$

First electrode is located at $0.0 \mathrm{~m}$.

(b)

Model P wth topography

embes.bin

Elevation teration 5 RMS error $=5.1$

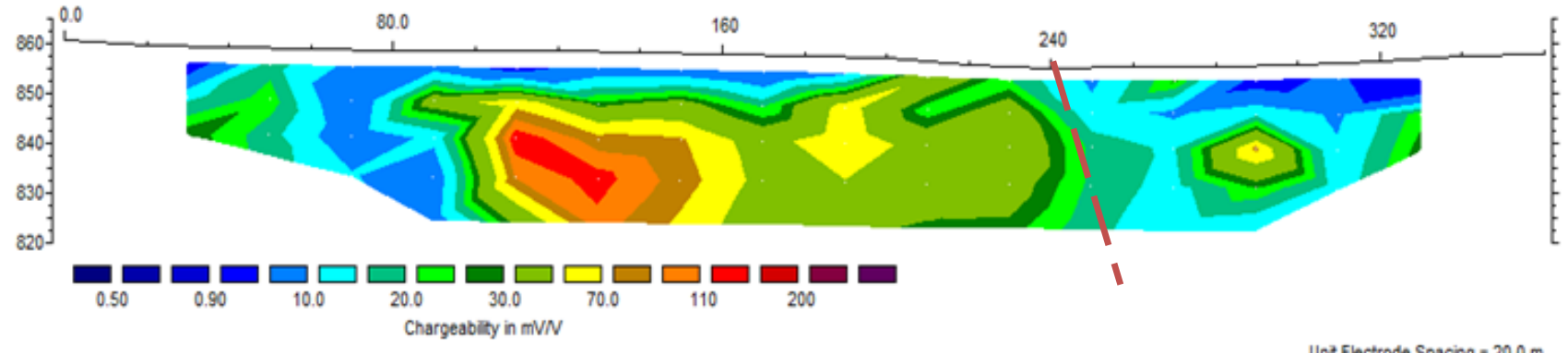

Horizontal scale is 53.63 picels per unt spacing

Vertical exaggeration in model section display $=1.04$

First electrode is located at $0.0 \mathrm{~m}$.

Last electrode is located at $360.0 \mathrm{~m}$

Figura 6.24: Resultado da inversão de resistividade (a) e cargabilidade (b) para o CE04, com posição de contato.

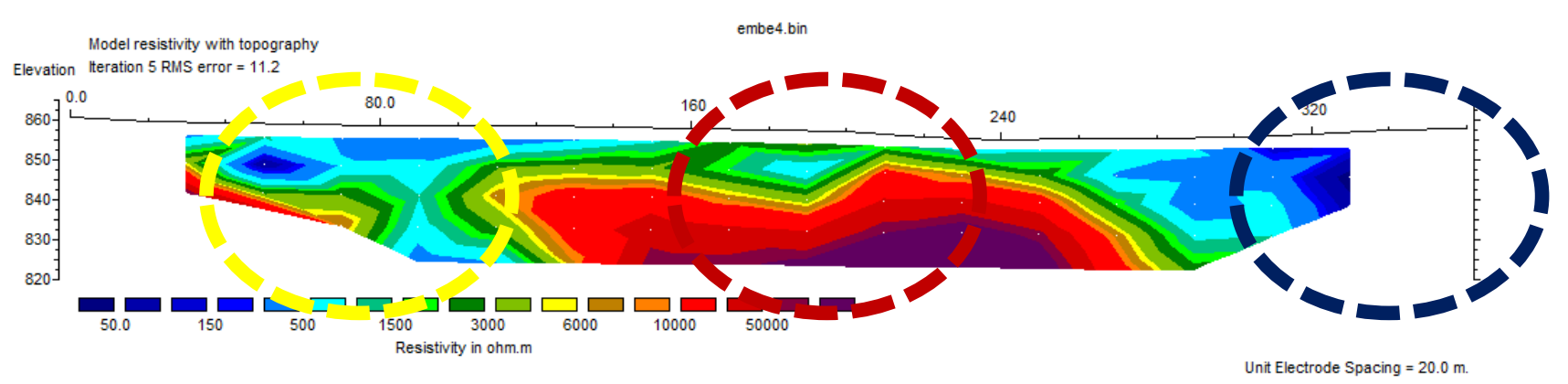

Figura 6.24 (c): Cópia da seção de resistividade para o CE04, onde o círculo amarelo representa a área de encontro entre o CE04 e SEV07, o círculo vermelho a área entre o CE04 e a SEV06. Já o círculo azul a região de contato entre o CE04 e a SEV05. 
Como o CE02 estava afastado dos demais, optou-se por deixa-lo por último. Na Figura 6.25 pode ser visualizado o resultado da inversão dos dados para este caminhamento. Importante ressaltar que a escala de cores tanto para os valores de resistividade quanto para os de cargabilidade são as mesmas dos outros caminhamentos.

$\mathrm{Na}$ Figura 6.25(a) é possível identificar que a partir de $60 \mathrm{~m}$ há em profundidade um corpo resistivo, com resistividade gradando de 3000 a 10000 Ohm.m o que nos faz interpreta-la como gnaisse. A anomalia deste corpo continua até $160 \mathrm{~m}$, sendo que em $140 \mathrm{~m}$ o contato fica em diagonal. Assim nesta localização estaria o contato entre o gnaisse e o xisto. Ao observarmos a seção de cargabilidade notamos um comportamento bem semelhante. A partir de $60 \mathrm{~m}$ se estendendo até $120 \mathrm{~m}$, identifica-se uma anomalia de baixa cargabilidade condizente com o gnaisse. De 120 até $240 \mathrm{~m}$ identifica-se um valor de cargabilidade mais elevado, condizente com o xisto. Entretanto estes valores não são uniformes, pois existem pequenas discrepâncias com regiões com valores menores como a faixa entre 180 e $220 \mathrm{~m}$ e regiões com valores maiores como a região entre $160 \mathrm{~m}$ e 180m.

O início deste caminhamento coincide com a SEV10, que encontrou gnaisse, concordante com o ensaio de caminhamento elétrico. Dessa forma, esses resultados indicam uma mudança na posição do contato previamente mapeado. 
(a)

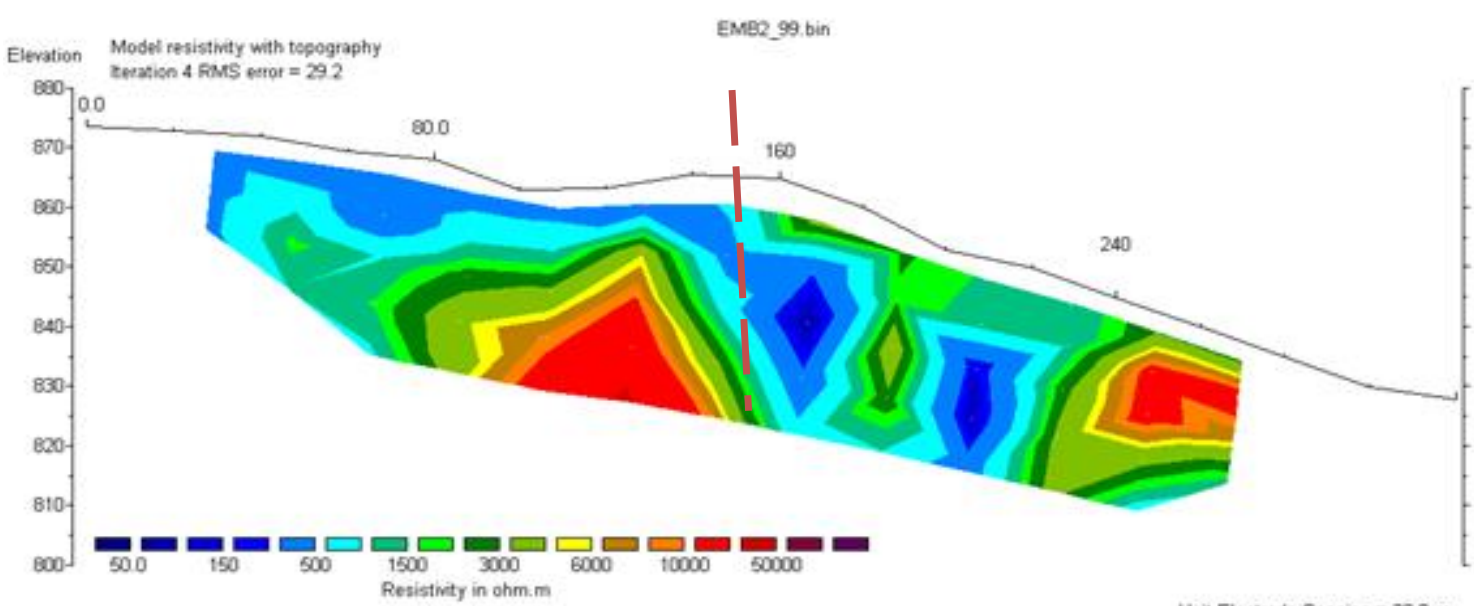

Horizonal seale is 60.47 gixels per unt spacing

Vertical exaggeration in model section display $=1.44$

Finst electrode is located at $0.0 \mathrm{~m}$

Last electrode is located at $3200 \mathrm{~m}$

(b)

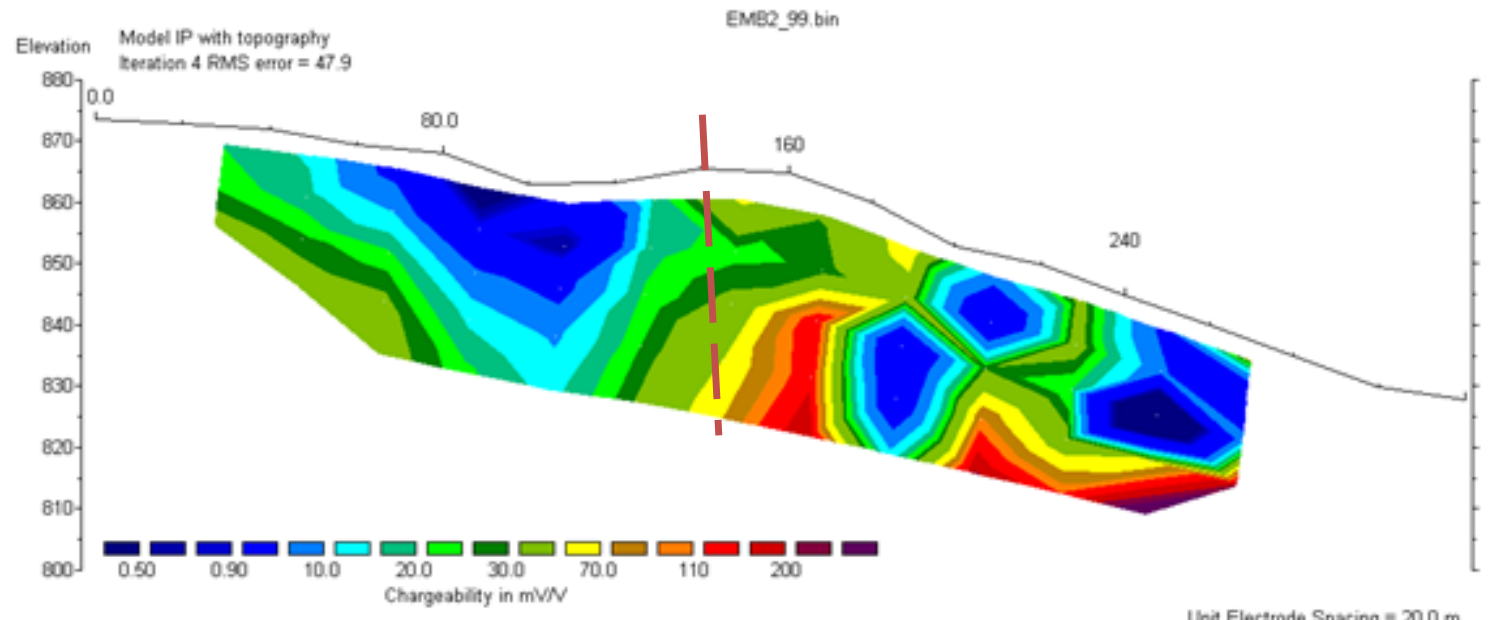

Horizontal scale is 60.47 gixels per unit spacing

Unit Electrode Spating $=20.0 \mathrm{~m}$

Vertical exaggeration in model section dsplay $=1.40$

Finst electrode is lotated at $0.0 \mathrm{~m}$.

Last electrode is located at $3000 \mathrm{~m}$

Figura 6.25: Resultado da inversão de resistividade (a) e cargabilidade (b) para o CE04.

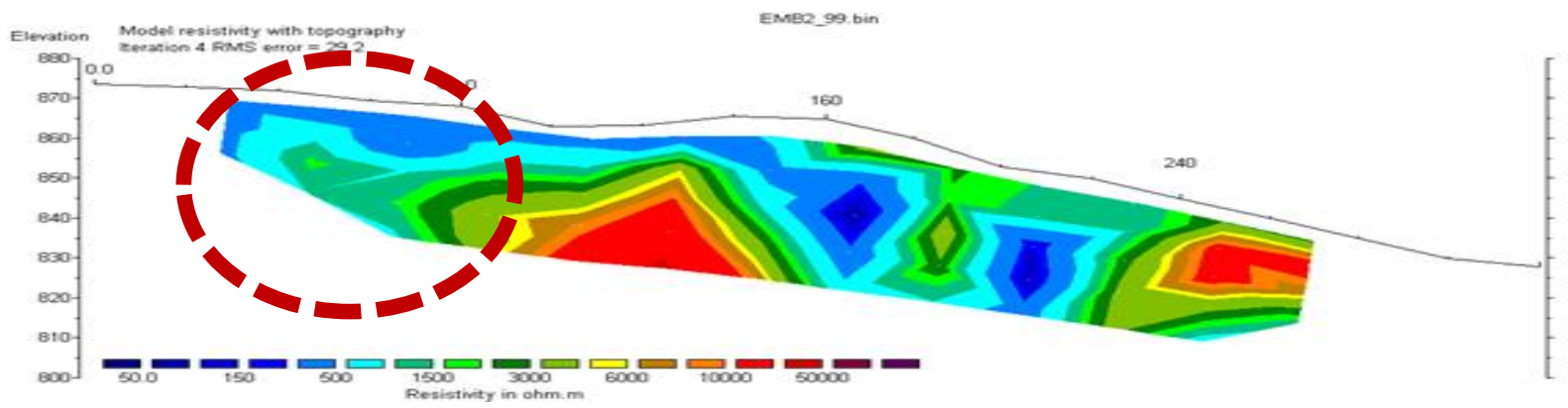

Figura 6.25 (c): Cópia da seção de resistividade (a), onde o círculo vermelho representa a área de intersecção entre o CE04 e a SEV10. 


\section{Planejamento de LAVRa}

De acordo com Junior A., 2010, planejar e modelar uma mina é complexo, pois envolve, entre outras coisas o planejamento da lavra, visando a evolução temporal ou o sequenciamento da lavra. Assim, avaliar corretamente a geometria da rocha a ser explorada bem como a determinação da sua qualidade é um problema enfrentado pelas mineradoras. Inicialmente deve ser feito um planejamento de lavra na mina a ser explorada, onde são definidos a evolução temporal ou o sequenciamento da lavra, além dos parâmetros fundamentais que orientação todas as atividades de mineração durante toda a vida útil da jazida.

Senhorinho 2008, diz que incorporar incertezas em um planejamento de lavra permite qualificar o risco geológico e melhorar o suporte no processo decisório. Nader B. et al, 2012 complementa dizendo que as incertezas geológicas podem diminuir mas nunca serão eliminadas uma vez que apenas podemos conhecer completamente uma jazida mineral após a sua exaustão. Junior, A. de F., 2010, concorda com esse ponto de vista, mas cita que o aprimoramento do modelo geológico ou a confiabilidade na modelagem pode aumentar com campanhas de amostragem, como sondagens rotativas.

Em Passos et al, 2010 é possível encontrar um exemplo de quão maléfico pode ser não ter um bom modelo geológico de uma mina a céu aberto. Neste artigo, em uma mina foi removido continuamente durante quatro anos, o estéril na parte central. Entretanto ao ser feito um estudo mais detalhado englobando uma modelagem da mina e sequenciamento de lavra notou-se que o estéril deveria ser primeiramente retirado das extremidades da mina e não da parte central.

Para Nader B. et al, 2012, a integração em cadeia é muito importante no setor da mineração. Nesse âmbito a geofísica é uma excelente ferramenta a ser integrada junto à engenharia e a geologia para se desenvolver um planejamento de lavra mais robusto. 
Com isso, a partir dos resultados adquiridos neste trabalho, pode se melhor delimitar os contatos geológicos nas extremidades da pedreira Embu. Podemos citar como os resultados mais expressivos, a SEV04, que de acordo com o mapa estaria em área de gnaisse, mas a sondagem apresentou resistividades muito baixas para essa litologia e as linhas CE02 e CE04, que estão um pouco discordantes do esperado pelo mapa geológico da área da pedreira. Além disso, as interpretações dos caminhamentos, da SEV 13 (gnaisse com 27 metros de espessura sobre o xisto) e da sondagem TDEM1 (gnaisse com cerca de 300 metros de espessura sobre 0 xisto) corroboraram o modelo de mergulho das camadas para SE.

No mapa apresentado na Figura 6.26 pode-se visualizar a distribuição das litologias previamente mapeadas. Observa-se que a partir da SEV 13 em direção ao norte uma linha pontilhada que indica o novo contato definido pelos resultados da SEV 10 e do caminhamento 02. A sul, próxima da SEV 4, também é apresentado o novo contato, em razão dos resultados geofísicos.

Assim podemos concluir que na região da pedreira Embu, os conjuntos de ensaios geofísicos possibilitou definir melhor os contatos geológicos e com isso pode-se criar um planejamento de lavra a curto e longo prazo mais acurado. 

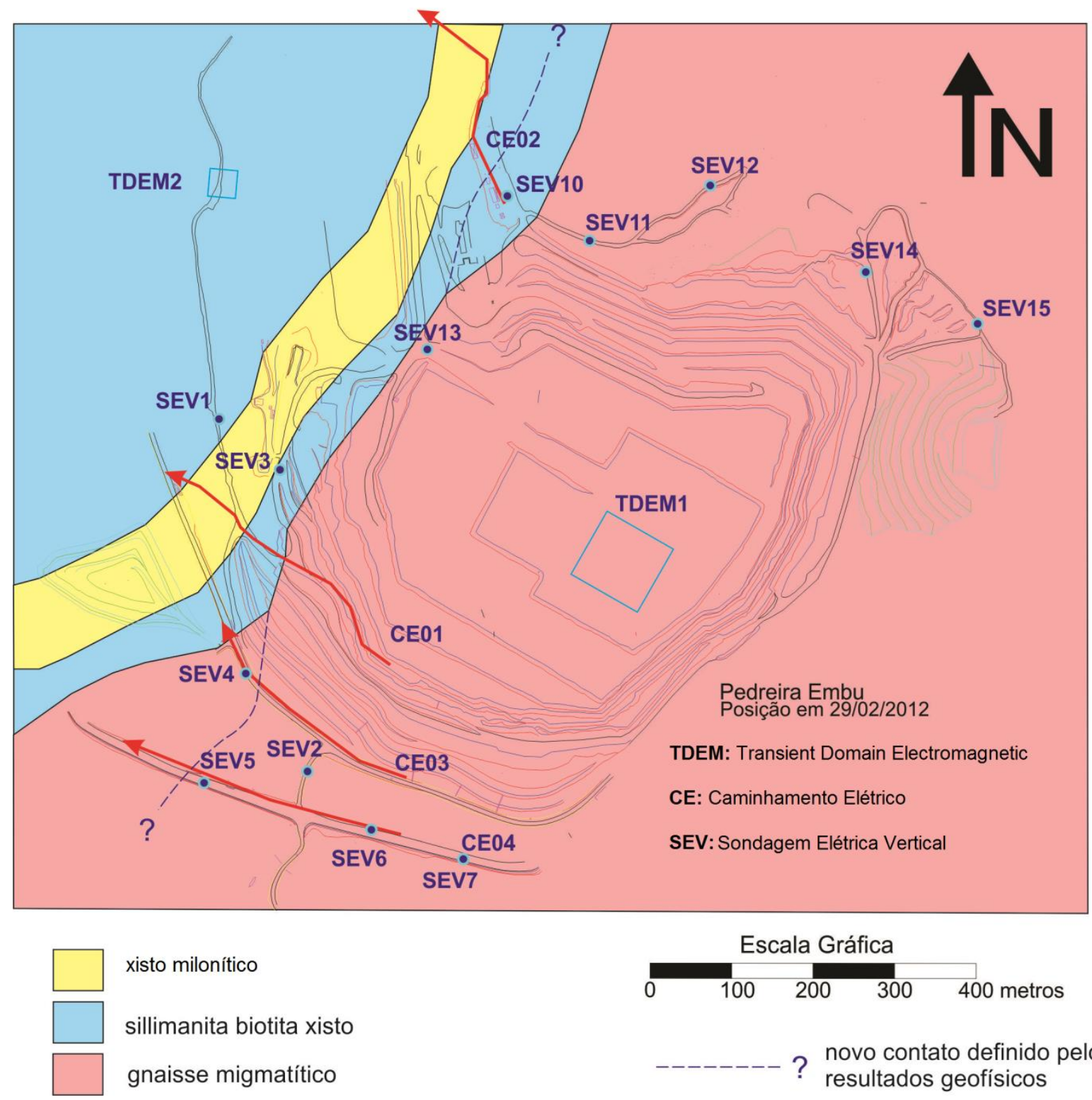

xisto milonítico

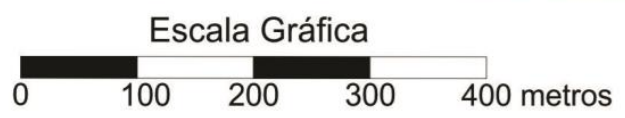

sillimanita biotita xisto

gnaisse migmatítico

? novo contato definido pelos resultados geofísicos

Figura 6.26: Mapa geológico com as novas posições dos contatos (traço pontilhado), a partir da interpretação geofísica. As setas vermelhas indicam a direção de aquisição dos caminhamentos. 


\section{CONCLUSÕES E CONSIDERAÇõES FINAIS}

De modo geral, os resultados de SEVs e caminhamentos permitiram mapear as rochas em subsuperficie, o que possibilitou o entendimento da disposição rochas em subsuperficie em toda a área bordejante a pedreira.

Especificamente os resultados das SEVs realizadas para estudo do capeamento possibilitaram delimitar o contato com a rocha sã em subsuperfície. As SEVs realizadas para estudar a variação litológica mostraram as relações entre o xisto e o gnaisse, como também a possível intercalação xisto-gnaisse na porção oeste da pedreira. Além disso, essas SEVs sugerem que o contato no mapa geológico deve ser reavaliado, especialmente a SEV04, que de acordo com o mapa estaria em área de gnaisse, mas a sondagem apresentou resistividades muito baixas para esse tipo de litologia.

Além disso, podemos dizer que os resultados dos caminhamentos elétricos também atingiram seu objetivo. Através do contraste de resistividade existente os tipos litológicos foi possível identificar de forma clara o contato entre o gnaisse, e o xisto em todas as quatro seções. Entretanto os resultados de cargabilidade não tiveram a mesma eficiência que os de resistividade.

Os resultados das linhas CE02 e CE04, quanto aos contatos entre as litologias, são um pouco discordantes do esperado pelo mapa geológico da área da pedreira. Dessa forma, sugerimos alterar as posições dos contatos de acordo com a interface dos ensaios geofísicos, caso não haja evidência litológica de superfície.

Assim, os resultados geofísicos desse trabalho associados ao resultado da sondagem TDEM e dos dados de atitude das camadas próximo ao contato xisto gnaisse corroboram o modelo de mergulho das camadas para SE. Assim, o conjunto de ensaios geofísicos realizados neste trabalho possibilitou definir melhor os contatos geológicos em algumas áreas e corroborar a interpretação estrutural em outras áreas. Com esses resultados, pode-se planejar as futuras frentes de lavra, a fim de maximizar os recursos da área estudada pelos próximos anos. 


\section{Referências Bibliográficas}

ABNT - Associação Brasileira de Normas técnicas. NBR 7211. Agregados para concreto - Especificações. Rio de Janeiro - 2009.

ABNT - Associação Brasileira de Normas técnicas. NBR 7525. Contentor flexível Determinação da resistência a queda operacional. Rio de Janeiro - 1989.

Alves, A., 2012. Avaliação de Informações Geofísicas e de Sondagem Rotativa para proposição de Mapa e Perfis Geológicos da Pedreira Embu. Relatório Interno Embu Engenharia, 10p.

Bhattacharya, P.K e Patra, H. P., 1968. Direct Current Geoelectric Sounding; Principles and Interpretation.

Braga, A. C. de O, 1999. Métodos Geoelétricos Aplicados. Módulo Hidrogeologia. Universidade Estadual Paulista. Rio Claro.

Braga, A. C de O, 2006. Métodos da Resistividade e Polarização Induzida aplicados no estudo da captação e contaminação de águas subterrâneas: Uma abordagem metodológica e prática. Trabalho de Livre Docência. Universidade Estadual Paulista. Rio Claro.

Bortolozo, C. A., 2011. Inversão Conjunta 1D de dados de SEV e TDEM: Aplicações em hidrogeologia. Dissertação de Mestrado, Universidade de São Paulo.

Embusa, 2012, Site da empresa EMBU S/A ENGENHARIA E COMÉRCIO: http://www.embusa.com.br, acessado em 30/01/2012

Elis, V. R., 1998. Avaliação da aplicabilidade de métodos elétricos de prospecção geofísica no estudo de áreas utilizadas para disposição de resíduos. Dissertação de Doutorado. Universidade Estadual Paulista. Rio Claro. Capítulo 3 e 4. 
Elis, V. R e Zuquette, L. V., 2000. Aplicação Integrada de Métodos Geolétricos em Áreas de disposição de Resíduos Industriais: Cidade de Franca, Brasil. Geotecnia, 92, 47-68p.

EXAME. Disponível em http://exame.abril.com.br/economia/noticias/construcao-civilno-brasil-deve-crescer-de-3-5-a-4-em-2013, acessado em 26/02/2014.

Ferreira, F. J. F., 2002. Técnicas e Aplicações de Imageamento Elétrico 2D e 3D. Curso de Pós Graduação em Geologia. Disciplina Geofísica Exploratória. Universidade Federal do Paraná. LPGA.

Gandolfo, O. C. B. e Gallas, J. D. F., 2007. O arranjo polo-dipolo como alternativa ao dipolo-dipolo em levantamentos 2D de eletrorresistividade. Revista Brasileira de Geofísica. 25(3). 227-235p

Geotomo Software Malaysia, 2011. Geolectrical Imaging 2D\&3D. Rapid 2-D Resistivity \& IP Inversion using the least-aquares method. Disponível em www.geoelectrical.com.

ICMM - Conselho Internacional de Mineração e Metais, 2013. O setor de mineração no Brasil: fortalecimento institucional para o desenvolvimento sustentável. Report Instituto Brasileiro de Mineração 2013, 115p.

IME, 2012, Instituto Militar de Engenharia. Seção de Ensino de Engenharia de Fortificação e Construção. Materiais de Construção II Tecnologia da Argamassa e do Concreto. Prof. MAJ MONIZ DE ARAGÃO Retirado do site: http://www.ime.eb.br/ moniz/matconst2/conc11.pdf acessado dia 30/01/2012.

INTERPEX LIMITED - 1993 - RESIX-IP v. 2.0 - DC Resistivity and Induced Polarization Data Interpretation Software. User's Manual. INTERPEX Limited, Golden, Colorado, U.S.A., 63p. 
Iris Instruments, Resistivity and Induced Polarization Measurements, acessado em 15/01/14 www.iris-instruments.com/Pdf\%20file/6-Induced_Polarization/current_waveform.pdf

Iris Instrument, 2012. Material retirado do site da companhia Iris Intrument em 28/06/2012. Website: www.iris-instruments.com/Pdf\%20file/R2_Gb.pdf

Junior, A. de F., 2010. Aprimoramento do controle de qualidade do minério no planejamento de lavra de curto prazo: Estudo de caso. Dissertação de Mestrado. Escola Politécnica da Universidade de São Paulo.

La Serna, H. A.; Rezende, M. M., Agregados para a construção civil. Pdf disponível no website http://anepac.org.br/wp/wp-content/uploads/2011/07/DNPM2009.pdf acessado em 24/01/2014 602-635p.

Malagutti, W.F.; Silva, R. W. da C., 2009. O emprego de métodos geofísicos na fase de investigação confirmatória em cemitérios contaminados. Engenharia Sanitária Ambiental, v. 14, n.3, 327-336p.

Ministério da Integração Nacional - MI, 2012. Companhia de Desenvolvimento dos vales do São Francisco e do Parnaíba. 1 Superintendência Regional - Montes Claros/MG. Anexo 1 - Especificações Técnicas. Protocolo: 59510.002215/2012-08

Moreira, C. A., Dourado J. C., 2005. Análise de contaminantes de fase líquida não aquosa (NAPLs) por aplicação do método eletromagnético indutivo (EM). Revista Brasileira de Geofísica, volume 23 n.3, Julho/Setembro 2005. São Paulo.

Moreira, C. A. et al., 2007. Aplicação do método eletromagnético indutivo (EM) no monitoramento de contaminantes em subsuperfície. Revista Brasileira de Geofísica, volume 25 n.4, Outubro/Dezembro 2007. São Paulo.

Nader, B., et al, 2012. Indicadores-chave de desempenho e a gestão integrada da mineração. REM: R. Escola Minas, Ouro Preto, 65(4), 537-542. 
Orellana, E., 1972. Prospección geoeléctrica en corriente continua. Segunda edición corregida y ampliada, Ed. Paraninfo, Madrid, 1982.

Passos A., Sahão H., De Tomi, G. Gestão sistêmica na mineração. Congresso da Associação Brasileira de Metalurgia, Materiais e Mineração, 2010, 65p.

Pormin1, 2012. Agregados Minerais Para Construção Civil: Areia Brita e Cascalho. Material fornecido no site do Portal do Apoio ao Pequeno Minerador do Ministério de Minas e Energia, http://www.Pormin1.gov.br/ acessado em 01/02/2012.

Pormin2, 2012. Métodos de Lavra. Material fornecido no site do Portal do Apoio ao Pequeno Minerador do Ministério de Minas e Energia, http://www.Pormin1.gov.br/ acessado em 01/02/2012.

Sampaio, J. A., Almeida, S. L. M. de, 2002. Obtenção de areia artificial com base em finos de pedreira. CETEM (Centro de Tecnologia Mineral), Ministério da Ciência e Tecnologia. Coordenação de Inovação Tecnológica (CTEC). Contribuição Técnica elaborada para a Revista Areia e Brita, CT2002-194-00. Rio de Janeiro, Dezembro 2002.

Santos, A. R. dos, 2002 Geologia de Engenharia: Conceitos, Método e Prática. São Paulo. Capítulo I e casos 2, 6, 12 e 18.

Santos, F. M., 2006. Manual de Prospecção Geofísica I. Capítulo 4: Técnicas para investigação de estruturas superficiais - $O$ método da resistividade. Instituto Dom Luis. Pode ser encontrado em http://idl.ul.pt/node/32?destination=node/32. Acessado dia 20/03/2012

Senhorinho, N. C., 2008. Método do planejamento estratégico de lavra incorporando riscos e incertezas para a obtenção de resultados operacionais. Tese para obtenção do título de Doutor. Escola Politécnica da Universidade de São Paulo. 
Silva, M. A. D., Familia real no Brasil: Doenças e práticas terapêuticas no período Joanino. Pesquisa apresentada ao PROVOC avançado. CAp-UERJ. 2009

Silva, R.W da C., Filho W. M., 2009. O emprego de métodos geofísicos na fase da investigação confirmatória em cemitérios contaminados. Engenharia Sanitária e Ambiental, volume 14, número 3. Rio de Janeiro.

Summer J.S, 1976. Principles of induced polarization for geophysical exploration. Elsevier Scientific Publishing Co. Amsterdam, 227p.

Telford, W. M., Gerald, L. P., Sheriff, R. E., 1990. Applied Geophysics, Cambridge University Press, $2^{\circ}$ edição. Cambridge University Press 860p.

Tonso, S., 1994. As pedreiras no espaço urbano: Perspectivas construtivas. Dissertação de Mestrado. Universidade Estadual de Campinas. Instituto de Geociências

Valverde, F. M., et al, 2001. Balanço Mineral Brasileiro. Capítulo: Agregado para a Construção Civil páginas 1-15. Disponível no site http://www.dnpm.gov.br/portal/assets/galeriaDocumento/BalancoMineral2001/agrega dos.pdf acessado no dia 02/02/2012.

Ward, S.H. \& Hohmann, G.W., 1987. Electromagnetic theory for geophysical applications. Investigations in Geophysic,. Electromagnetic Methods in Applied Geophysics. Society of Exploration Geophysicists. Ed. Misac N. Nabighian, v.1, n.3, 131-311p.

Yong, L., et al., 2011. Research on induced polarization effects of frequency-domain electromagnetic sounding of electric dipole source. Chinese jornal of geophysics. Vol 54, n 4. 568-579p. 